DEPARTMENT OF THE INTERIOR

U.S. GEOLOGICAL SURVEY

\title{
Sedimentary Basins of Offshore Alaska \\ and Adjacent Regions
}

by

Thomas J. Wiley*

Open-File Report $86-35$

This report is preliminary and has not been reviewed for conformity with U.S. Geological Survey editorial standards and stratigraphic nomenclature.

* Menlo Park, California 
TABLE OF CONTENTS

Introduction

Kaktovik Basin

Dinkum Graben

4

Nuwuk Basin

North Chukchi Basin

South Chukchi Basin and Alaskan North Slope

Hope Basin

Norton Basin

16

23

Anadyr Basin

Navarin Basin

27

31

Saint George Basin

36

Amak Basin

39

Bristol Bay Basin

44

Aleutian Basin

46

Pratt Depression

50

Buldir Depression

53

54

Amlia and Amukta Basins

55

Atka Basin, Aleutian Terrace Forearc Basin 58

Aleutian Trench

Sanak Basin

61

Shumagin Basin

64

Tugidak Basin

68

Albatross Basin

Stevenson Basin

Cook-Shelikof Basin

Gulf of Alaska Tertiary Province $\quad 85$

Middleton Segment $\quad 85$

Yakataga Segment $\quad 90$

Yakutat Segment $\quad 94$

Southeastern Segment $\quad 99$

Pacific Ocean Segment $\quad 102$

Queen Charlotte Basin 102

$\begin{array}{ll}\text { Appendix } & 109\end{array}$

$\begin{array}{ll}\text { References } & 110\end{array}$ 


\section{LIST OF IILUSTRATIONS}

Figures

1. Map of area covered in this report 2

2. Index map of sedimentary basins and list of
contributing geologists

3. Structure-contour map of Raktovik basin and Dinkum
graben

4. Kaktovik basin, basin history diagram 6

5. Dinkum graben, basin history diagram 8

6. Isopach map of Kaktovik and Nuwuk basins and
Dinkum graben

7. Nuwuk basin, basin history diagram 12

8. Time-depth plots for seismic velocities in North Chukchi basin and Chukchi shelf (South Chukchi basin), key to symbols for Figure 9

9. Isochronous maps of North and South Chukchi basins 14

10. North Chukchi basin, basin history diagram 15

11. South Chukchi basin, basin history diagram 18

12. Point Barrow to Icy Cape onshore, basin history diagram 19

13. Western North Slope, basin history diagram 20

14. Central North Slope, basin history diagram 21

15. Eestern North Slope, basin history diagram 22

16. Isopach map of Hope basin 24

17. Hope basin, basin history diagram 26

18. Structure-contour map of Norton basin 28

19. Norton basin, basin history diagram 30

20. Isopach map of Anadyr basin 32

21. Onshore Anadyr basin, basin history diagram 34

22. Offshore Anadyr basin, basin history diagram 35

23. Navarin basin, basin history diagram 38

24. Saint George basin, basin history diagram 40

25. Columnar section for Bristol Bay and Alaska

26. Columnar section for Nushagak lowlands 43

27. Amak basin, basin history diagram 45

28. Structure-contour map of Bristol Bay, St.
George, Amak, and Pribilof basins

29. Offshore Bristol Bay basin, basin history 48

30. Onshore Bristol Bay basin, basin history diagram 49

31. Aleutian basin, basin history diagram 51

32. Map and generalized cross section of the
Amlia Corridor

33. Amlia and Amukta basins, basin history diagram and isopach map $\quad 57$

34. Atka basin--Aleutian Terrace, basin history diagram 59

35. Aleutian Trench in Amlia Corridor, basin history 62

36. Aleutian Trench in Amlia Corridor, isopach map 63

37. Isopach map of Sanak basin 65

38. Sanak basin, basin history diagram 66 
39. Onshore Shumagin Shelf, basin history diagram 67

40. Isopach map of Shumagin basin fill 69

41. Shumagin basin, basin history diagram 70

42. Isopach maps of Tugidak basin 72

43. Tugidak basin, basin history diagram 73

44. Kodiak Island, basin history diagram 75

45. Structure-contour map of Albatross basin 76

46. Albatross basin, basin history diagram 77

47. Structure-contour map of Stevenson basin 80

48. Stevenson basin, basin history diagram 81

49. Maps and cross section of Cook-Shelikof basin 83

50. Cook-Shelikof basin, basin history diagram 84

51. Structure-contour map of the Middleton segment 86

52. Middleton segment, basin history diagram 88

53. Middleton segment onshore, basin history $\begin{array}{ll}\text { diagram } & 89\end{array}$

54. Structure-contour map of Yakataga segment 91

55. Yakataga segment offshore, basin history
diagram

56. Yakataga segment onshore, basin history
diagram

57. Structure-contour map of Yakutat segment 95

58. Yakutat segment offshore, basin history
diagram

59. Yakutat segment onshore, basin history
diagram

60. Map and seismic profiles of the Southeastern
Alaska segment

61. Southeastern Alaska segment, basin history diagram 101

62. Thickness map of sediment in the Pacific Ocean

segment 103

63. Pacific Ocean segment, basin history diagram 104

64. Isopach map of queen charlotte basin 106

65. Queen Charlotte basin, basin history diagram 107

Plates

1. Map of sedimentary basins of offshore Alaska and adjacent regions 


\section{INTRODUCTION}

This report summarizes published information for offshore sedimentary basins of Alaska and adjacent regions (Figures 1 and 2) including: (1) onshore extensions of offshore basins and (2) several basins of western Canada and eastern U.S.S.R.

For each basin there is an isopach or structure-contour map (where available), a basin history diagram, and descriptive text. Other authors' original isopach and structure-contour maps are presented as figures with the text (See Figure 2 for a list of contributors to this compilation). These maps have also been compiled on an Albers equal area projection at a scale of $1: 2,500,000$ with a 1 kilometer contour interval (Plate 1). Where more than one horizon has been mapped, Plate 1 shows the oldest or most representative horizon; maps of other horizons may appear as figures with the text. For some areas seismic profiles, line drawings of seismic profiles, or cross sections are shown.

Other authors' stratigraphic columns have been compiled onto basin history diagrams that show time vertically along a left-side column ( $t$ ime scale of Harlan and others, 1983) and thickness and lithology (See Appendix for key to symbols) vertically along a right-side column. Most of the basin history diagrams are drawn at the same scale, allowing direct visual comparisons of sedimentation rates, age and duration of unconformities, distribution of lithologies, and other parameters.

The subjects covered in the text--where the information is available--are listed below:

1. General information--including the basin's location, area, maximum thickness of sedimentary rocks, age of basin fill, and water depth.

2. Geologic and geographic boundaries.

3. Basin shape.

4. Structural Geology.

5. Basement.

6. Basin type.

7. Stratigraphy--including textural trends, coarse-grained units, shapes of sedimentary units, volcanism, plutonism, deformation, and metamorphism.

8. Prominent seismic horizons.

9. Gravity.

10. Magnetics.

11. Petroleum geology--including geothermal gradient, source rocks, maturation, diagenesis, and oil and gas bearing rocks.

12. Availability of maps and other illustrations--including location, thickness, isopach, and structure contour maps; seismic profiles and line drawings; cross sections; and stratigraphic columns.

13. Degree of coverage.

14. Other information.

15. Recent references.

The basins are listed in rough geographical order from north to south. 


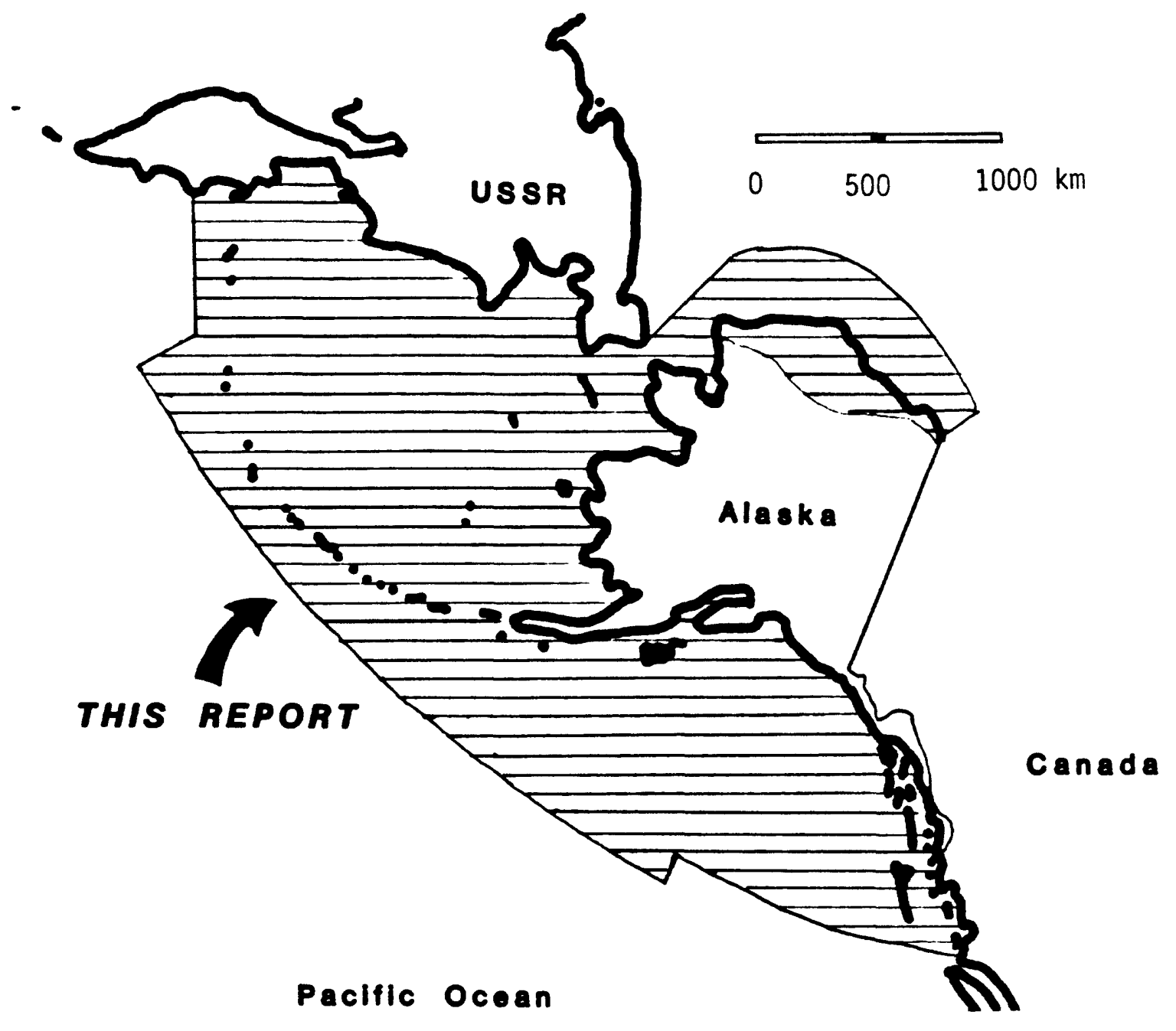

Figure 1 


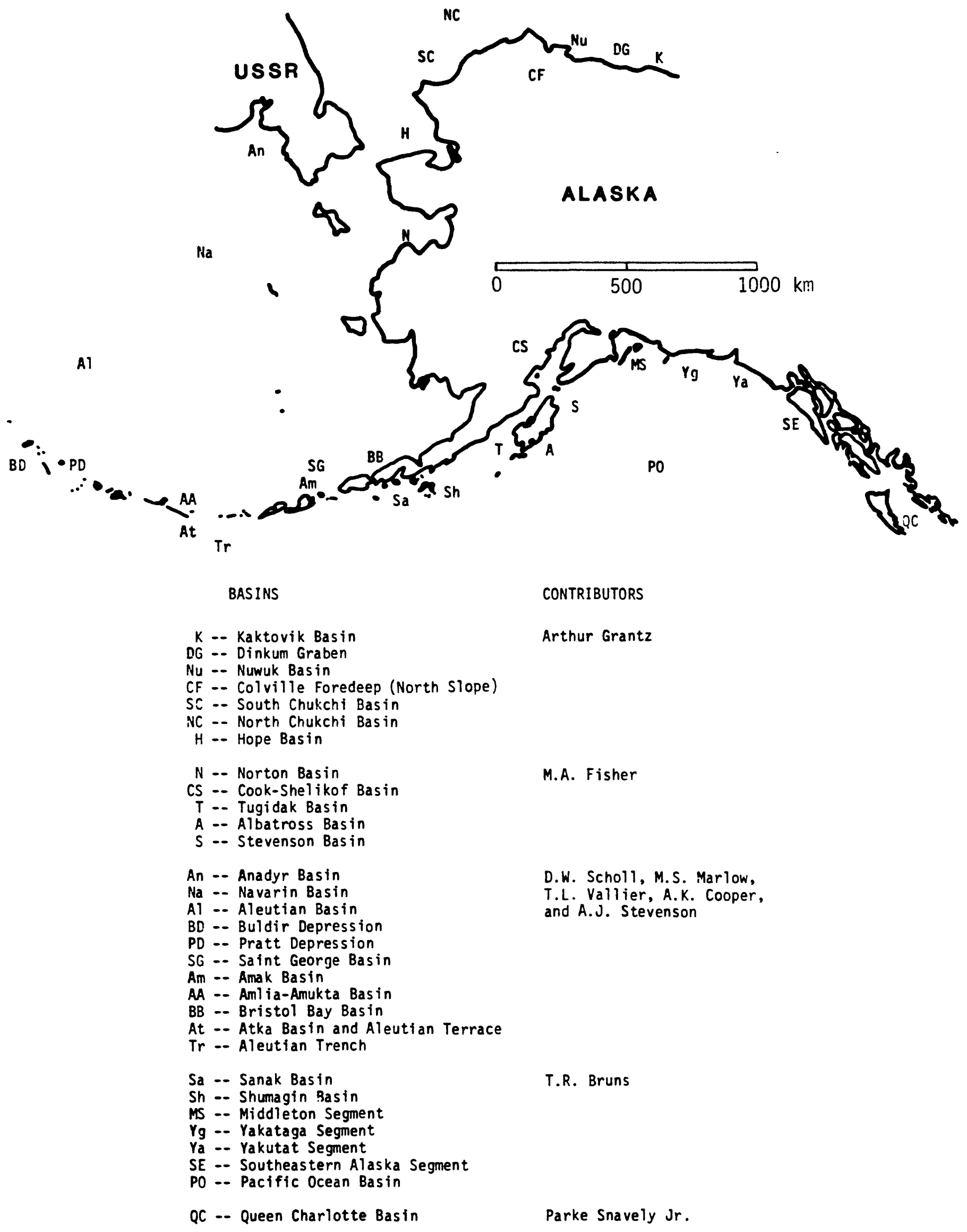

Figure 2. Index map to basins described in this report and a list of the geologists contributing to its preparation. 


\section{EARTOVIK BASIN}

General Information-- Raktovik basin is located off the Arctic coast of Alaska at lat. $70^{\circ} \mathrm{N} .$, long. $141-145^{\circ} \mathrm{W}$. It has an area estimated at 14,000 square $\mathrm{km}$ and, offshore, reaches water depths of up to $2800 \mathrm{~m}$. More than 12.5 $\mathrm{km}$ of Jurassic and younger sedimentary rocks fill the basin. Kaktovik basin lies within the Diapir Field planning area.

Geologic and Ceographic Boundaries-- North of Kaktovik basin lie the shelf break, a field of diapirs, and Canada Basin (Figure 3). To the west is Nuwuk basin. Barter Island lies along the southern boundary of the basin and Demarcation Point is to the southeast. The Alaska-Canada Border and Mackenzie River delta are east of the basin.

Basin Shape- Raktovik basin is elongate in an east-west direction. It is deepest to the east and open to the north. East of Barter Island the middle to upper Tertiary sequence occurs in two subbasins, Demarcation subbasin (thickness $7.2 \mathrm{~km}$ ) in the southeast and Barter Island subbasin in the northwest.

Structural Ceology-- Diapiric shale ridges and associated diapir-driven normal faults occur east of Barter Island (Grantz and May, 1983). These ridges are 40 to $75 \mathrm{~km}$ long by 5 to $10 \mathrm{~km}$ wide and show as much as $6.5 \mathrm{~km}$ of upward penetration. Jurassic, Cretaceous, and Paleogene fine-grained sedimentary rocks are inferred to form the diapir cores. Flanking units dip away from ridges. There is evidence for three episodes of diapiric movement (Grantz and others, 1982a). A regional subsurface horizon of possible middle Eocene age is present in the area of the diapiric ridges. One of these ridges separates the two subbasins.

Northeast-striking linear folds 40 to $90 \mathrm{~km}$ long by $20 \mathrm{~km}$ wide are Quaternary detachment folds. These include the camden detachment anticline and parallel folds west of Barter Island which are active today (Grantz and others 1982a; Grantz and May, 1983). North-dipping growth faults lie west of Barter Island (Grantz and other, 1982a). Kaktovik basin fill is underlain by Dinkum Graben in the west.

Basement- A gently sloping surface at the top of the Franklinian sequence (pre-Mississippian) forms the basement beneath most of the basin. The northern parts of the basin may be underlain by transitional or oceanic crust. terrace.

Basin Type- Kaktovik basin is a progradational continental margin prism

Stratigraphy-- Prior to the Jurassic, the sediment source lay to the north; throughout Brookian time (Jurassic and younger), the sediment source lay to the south. Rocks of the Brookian sequence form a northward-thinning wedge of clastic strata. Iocally, the presence of several northward-thinning wedges of Ellesmerian strata (Mississippian thru Jurassic) has been extrapolated from onshore exposures. Texturally mature sandstone and conglomerate are common in strata of the Ellesmerian sequence in adjacent onshore areas.

Prominent Seimic Borizons-- In Demarcation subbasin, three angular unconformities are present in the Brookian sequence (Figure 4). The uppermost of these $(U-3)$ separates Neogene marine and nonmarine sedimentary rocks from mid-Tertiary (Eocene and oligocene?) rocks. The second unconformity (U-2) lies within the mid-Tertiary section. The oldest unconformity, the "middle Eocene" unconformity $(U-1)$, is overlain by the mid-Tertiary section and is underlain by lower Tertiary, Cretaceous, and Jurassic marine sedimentary rocks. Where an acoustic-basement horizon is present, it is inferred to represent the top of the Franklinian sequence or possibly wedges of the 


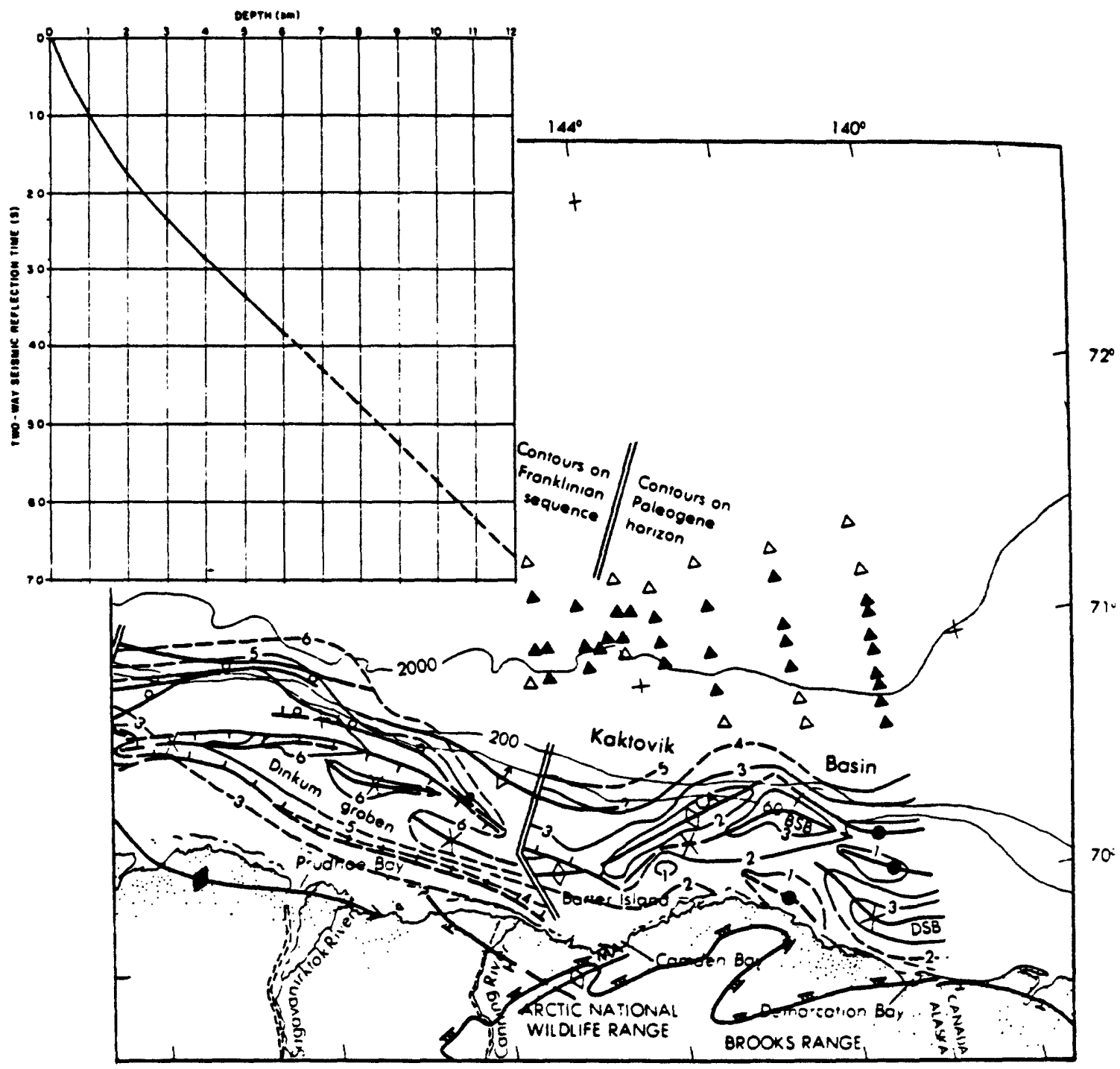

- $\Delta$ Crossing of diapiric fold. Open symbol shows possibly drapiric brood fold.

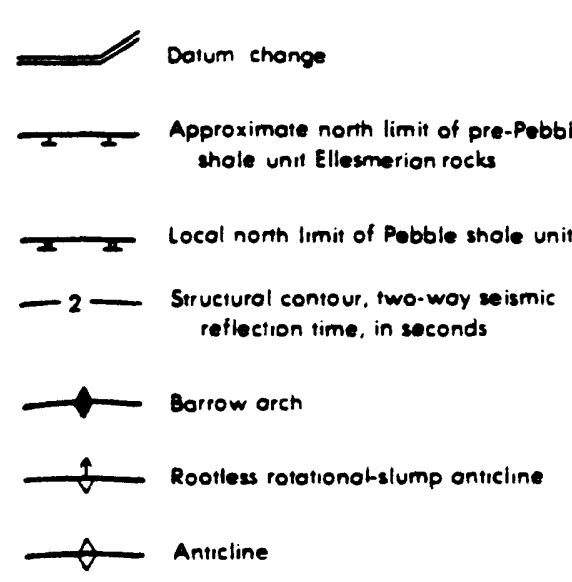

-200 Isobaths, 60.200 , and $2000 \mathrm{~m}$

CA Comden onticline

Ma Morsh onticline

DSB Demarcation subbasin

BSB Borter lsland subbasin

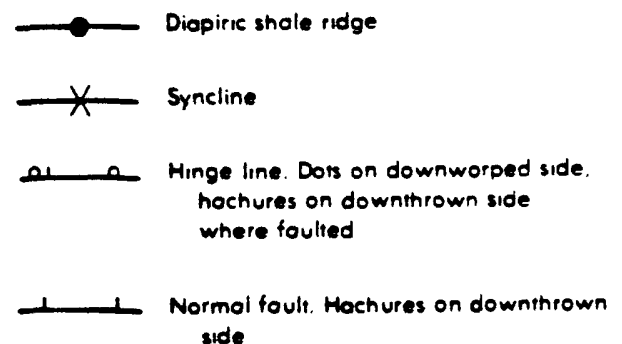

Figure 3. Structural geologic map of Kaktovik basin and Dinkum graben. A11 lines dashed where inferred or projected. Inset shows generalized average seismic-reflection time as a function of depth for Beaufort shelf. From Grantz and others, 1982a, Figures 4 and 5. 


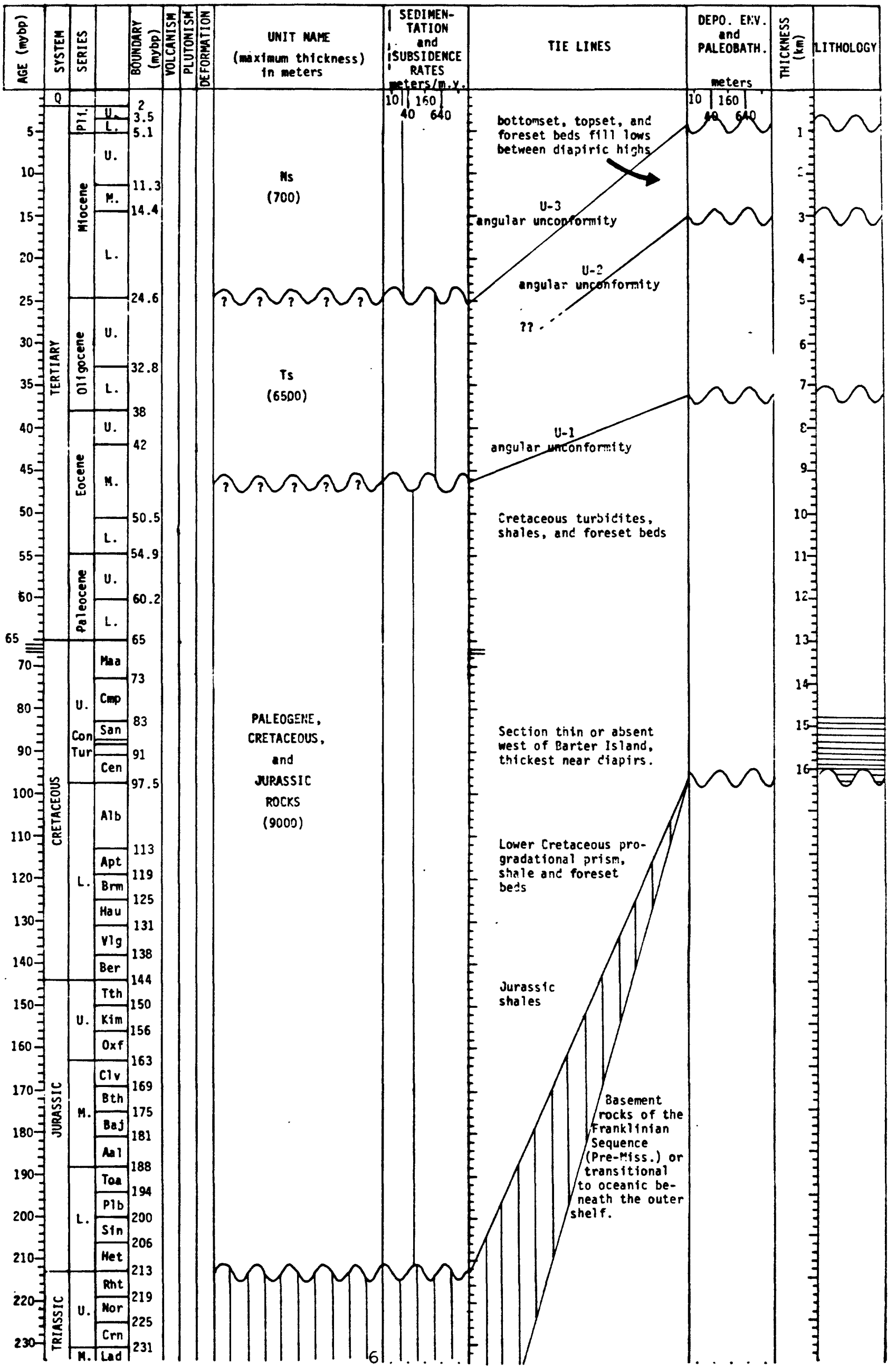


Ellesmerian sequence in southern parts of the basin, and an unknown, transitional or oceanic basement beneath the northern parts of the basin.

Gravity-- See Ruppel and McHendrie, 1976.

Petroleum Geology-- Basin filling strata buried at depths from 3 to $6 \mathrm{~km}$ are within the oil generation window. This includes the upper parts of the diapirs and the deep parts of the subbasins. Some young folds probably postdate the migration of oil.

Maps and Other Illustrations-- Location and thickness maps are included with seismic profiles in Grantz and May, 1983. Location, isopach, and structure contour maps along with seismic profiles, cross sections, and stratigraphic columns appear in Grantz and others, 1982a.

Degree of coverage-- A multi-channel seismic grid with $30 \mathrm{~km}$ spacing covers Kaktovik basin.

Other Information-- Jurassic and Cretaceous strata are thin or absent west of Barter Island. Diapiric structures underlie the adjacent continental slope and rise.

References-- For more detailed information see Grantz and others, 1982a; Grantz and May, 1983, 1984b; and Ruppel and McHendrie, 1976.

\section{DIMLUY GRABET}

General Information-- Dinkum graben is located at lat. $70^{\circ} 30^{\prime} \mathrm{N} .$, long. $148^{\circ} \mathrm{W}$. (Figure 3). Its area is estimated as 4250 square $\mathrm{km}$. Water 25 to 100 $\mathrm{m}$ deep covers the basin. Of the $10.6 \mathrm{~km}$ total thickness of sedimentary rocks (Figure 5), $4.7 \mathrm{~km}$ are Jurassic and Early Cretaceous graben fill and $5.9 \mathrm{~km}$ are younger rocks of Kaktovik basin which overlie the graben. Dinkum Graben lies within the Diapir Field planning area.

Geologic and Geographic Boundaries-- The northern boundary of the graben is formed by a south-dipping normal fault with 2 to $4.7 \mathrm{~km}$ displacement. The southern boundary is formed by a northward-dipping normal fault or faulted flexure. Displacement on the bounding faults decreases to near zero in the west. The graben is cannot be resolved beneath Kaktovik basin in the east.

Basin Shape-- Dinkum graben is elongate along an east-southeast to westnorthwest trend. It is $170 \mathrm{~km}$ long by 10 to $40 \mathrm{~km}$ wide and is deeper to the east. In north-south cross section the graben is asymmetric, deeper to the north.

Structural Ceology-- Normal and antithetic faults parallel the basin trend. Graben formation stopped by Turonian time $(89 \mathrm{Ma})$; it probably began in the Jurassic (Grantz and May, 1983).

Basement-- Basement of Franklinian (pre-Mississippian) rocks forms a north-dipping slope beneath the graben's southern side (Grantz and May, 1983). Crustal basement is probably continental beneath the southern side of Dinkum Graben, and may be transitional or oceanic under the northern side.

Basin Type-- Dinkum graben is an asymmetric graben or half-graben, a rift valley basin. It is underlain by the older Ellesmerian (Mississippian thru Jurassic) Arctic Alaska basin (an intracratonic basin), and is overlain by the sedimentary fill of Kaktovik basin (a continental margin prism terrace).

stratigraphy-- Within the basin, bedding diverges to the north. Northward dips of 2.5 to 12 degrees are common throughout most of the basin; southward dips occur near the northern boundary fault. The basin is overlain by the northward prograding clastic sequence of Kaktovik basin (Figure 5).

Prominent Selenic Borizons-- Two prominent seismic horizons probably represent (1) the "breakup unconformity" at the base of the cretaceous Pebble Shale and (2) the unconformity above the Franklinian sequence (basement) on the southern side of the graben (Grantz and May, 1983). 


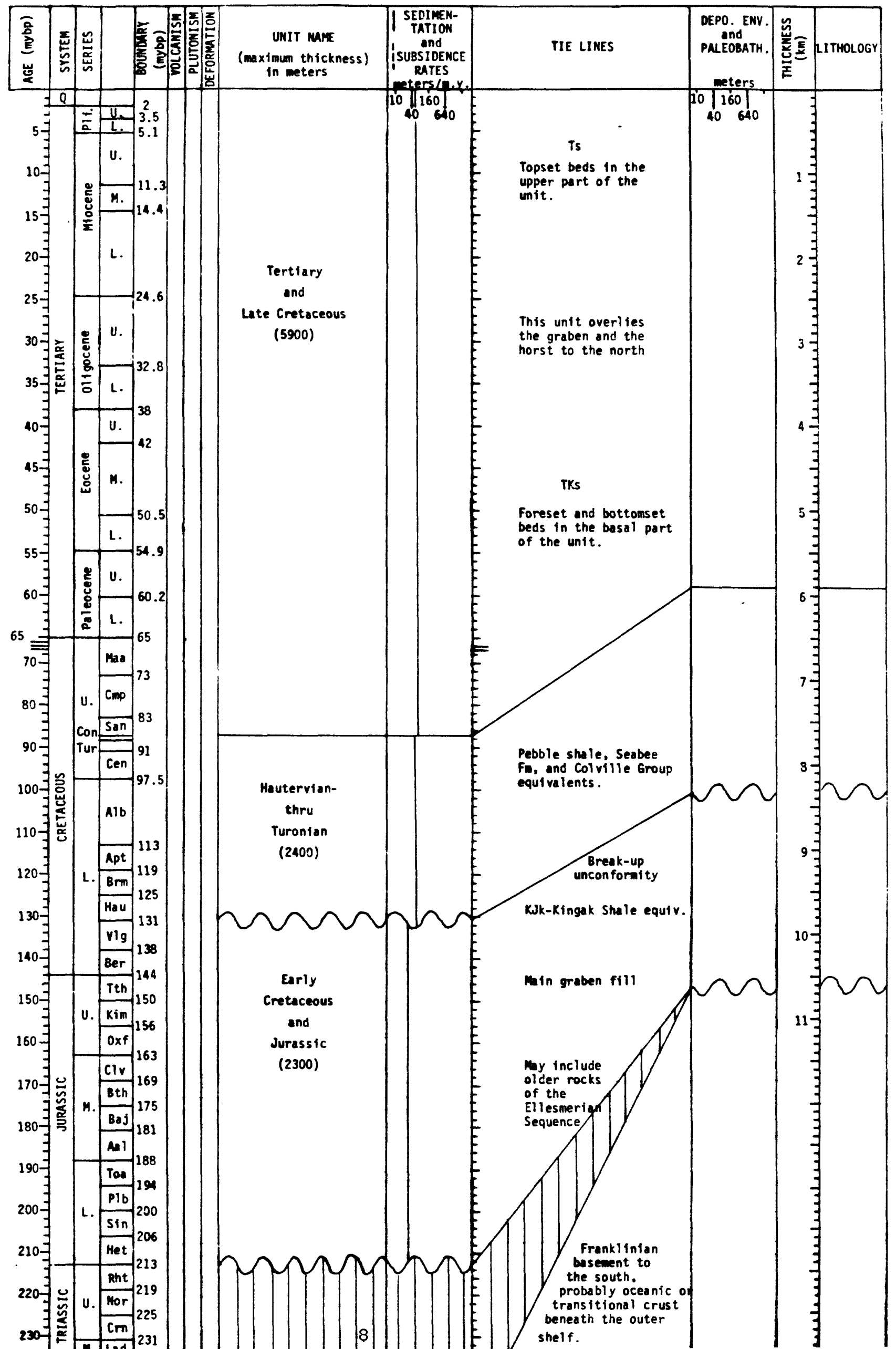


Petroleum Geology-- Lowest Tertiary and Cretaceous rocks are estimated to lie within the oil generation window, pre-Cretaceous rocks are probably overmature, but may have been source rocks in the past.

Maps and Other Illustrations-- Maps in Grantz and May (1983) show the graben's location and thickness. Location, isopach, and structure-contour maps appear with seismic profiles and stratigraphic columns in Grantz and others, $1982 a$.

Other Information-- The younger sediments that overlie Dinkum Graben (Kaktovik basin) extend laterally into the Tertiary section onshore.

References-- For more detailed information see Grantz and others, 1982a; and Grantz and May, 1983, $1984 \mathrm{~b}$.

\section{MUNUK BASIN}

General Information-- Nuwuk basin is located between lat. $72^{\circ} \mathrm{N} .$, long. $156^{\circ} \mathrm{W}$. and lat. $71^{\circ} 20^{\prime} \mathrm{N}$, long. $151^{\circ} \mathrm{W}$ (Figure 6). Its area is about 15,000 square $\mathrm{km}$. Water depths range up to $4000 \mathrm{~m}$. More than $12.6 \mathrm{~km}$ of early Cretaceous and younger sedimentary rocks fill the basin. Nuwuk basin lies in the Diapir Field planning area.

Geologic and Coographic Boundaries-- North of Nuwuk basin is the shelf break and, beyond that, Canada Basin. Nuwuk basin's northwestern boundary probably lies along the Northwind fracture zone. In the southwest, a faulted hinge line and Barrow arch bound the basin. Smith Bay is located near the southern boundary of the basin and Harrison Bay is near the southeastern boundary. In the east, the basin extends to about long. $151^{\circ} \mathrm{W}$.

Basin Shape-- The basin is elongate, $300 \mathrm{~km}$ long by $50 \mathrm{~km}$ wide. The western half of the basin trends north-northwest, and the eastern half trends west-northwest. The basin is open to the north.

structural Geology-- The most intense period of deformation accompanied basin formation in the Jurassic and Early Cretaceous. Down-to-the-northeast listric growth faults formed a multi-strand system in the Late cretaceous or early Tertiary, parts of which are still active (Grantz and May, 1983; Grantz and others, 1982a). Large anticlines have formed as a result of backward rotation along these growth faults. The anticlines are best developed in Albian and Upper Cretaceous strata on the outer shelf and slope.

Basement-- Basement is inferred to change from continental crust--the pre-Mississippian Franklinian sequence of the Arctic Platform--in the south and southwest to transitional or oceanic crust in the north and northeast (Grantz and others, 1982a). The "breakup" unconformity, thought to represent rifting associated with opening of the Arctic Ocean, lies on acoustic basement under the southern side of the basin, along a down-to-the-north normal fault.

Basin Type- Nuwuk basin is a progradational continental terrace sediment prism. It is underlain in the south by an older basin, the Ellesmerian (Mississippian thru Jurassic) Arctic Alaska basin, an intracratonic rift basin.

Btratigraphy-- The source of basin-filling sediment has been to the south and southwest since Jurassic time but, prior to the Jurassic, the source terrane for Ellesmerian strata lay to the north.

Coarse-grained units, including texturally mature sandstone and conglomerate, occur in the Ellesmerian sequence.

The Brookian sequence (Jurassic and younger) consists of northwardprograding clastics showing foreset and topset beds, numerous large erosional channels, and channel fills (Grantz and May, 1983; Grantz and others, 1982a).

Prominent Seianic Borizons-- Three prominent seismic horizons have been interpreted as the base of Neogene(?) strata, the base of Senonian(?) strata, 


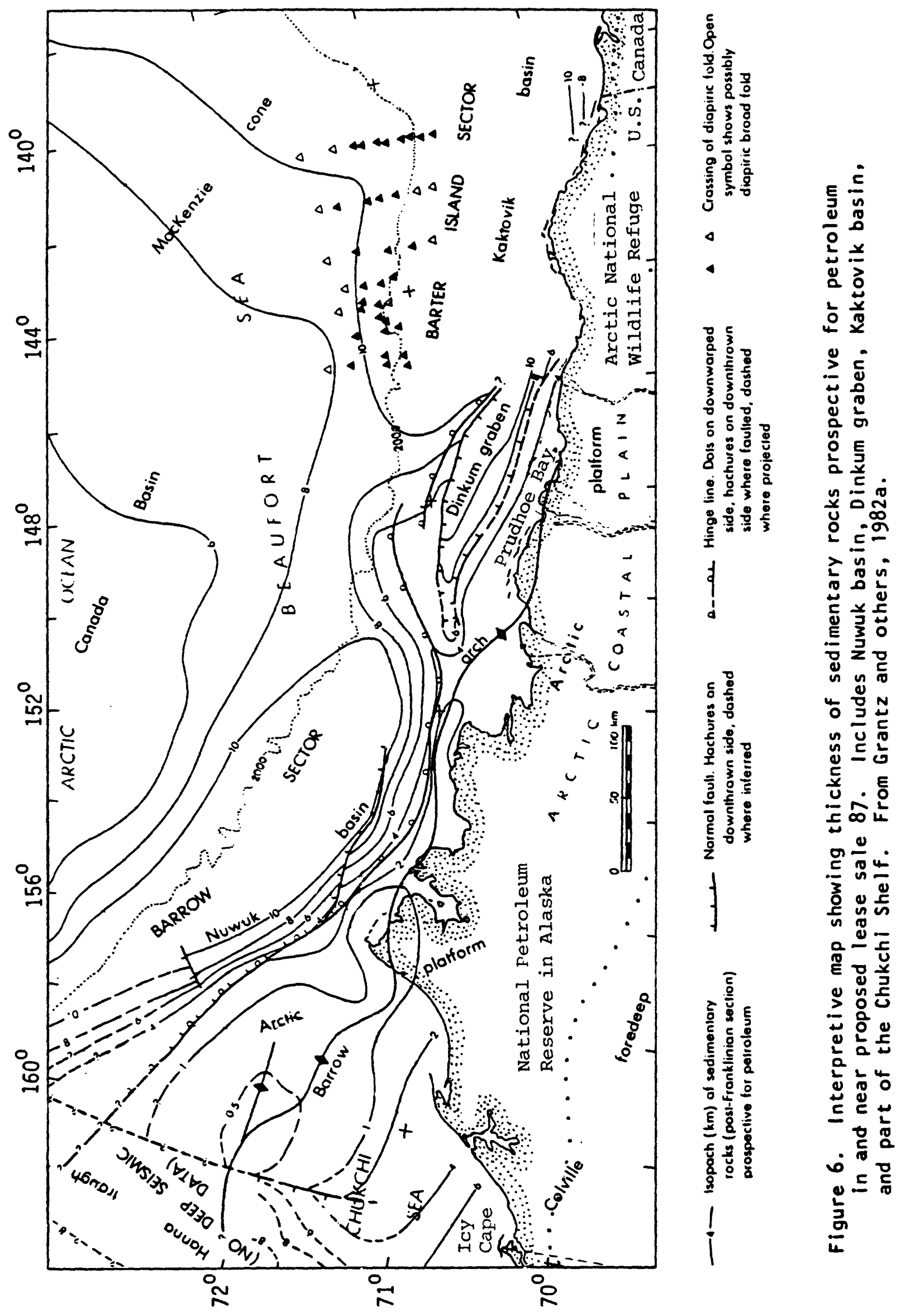


and the top of Neocomian strata (Grantz and May, 1983). The horizon at the top of the Neocomian--the "breakup unconformity"--lies at the top of acoustic basement throughout amuch of the basin (Figure 7).

Petroleum Gology-- The oil generation window lies between 3 and $6 \mathrm{~km}$ for the Brookian sequence.

maps and Other Illustrations-- Location, thickness, isopach, and structure maps are included with seismic profiles, cross sections, and stratigraphic columns in Grantz and others, 1982a. Stratigraphic columns appear in Grantz and May, 1983.

Degree of coverage-- About $600 \mathrm{~km}$ of 24 channel seismic, with $30 \mathrm{~km}$ line spacing, cover Nuwuk basin.

Other mformation-- Seaward progradation of a hingeline formed the sediment prism of Nuwuk basin (Grantz and May, 1983). A submarine canyon cut more than $1.4 \mathrm{~km}$ into seaward prograded Albian marine clastic deposits between Barrow and Harrison Bay and was then filled with Turonian marine sediments (Grantz, Eittreim, and Whitney, 1981)

References-- For more detailed information see Grantz and May, 1983, $1984 \mathrm{a}, \mathrm{b} ;$ Grantz and others, 1982a; and Grantz, Eittreim, and Whitney, 1981.

\section{MORTH CHUKCHI BASIN}

General Information-- North Chukchi basin is located at lat. $73^{\circ} \mathrm{N}$. , long. $167^{\circ} \mathrm{W}$. It has an area of more than 15,000 square $\mathrm{km}$. The basin fill of 11.6 $\mathrm{km}$ of Brookian strata (post mid-Lower Cretaceous) includes up to $7 \mathrm{~km}$ of upper Brookian (Tertiary) strata. As much as $2.5 \mathrm{~km}$ of Ellesmerian (Mississippian to mid-Lower Cretaceous) strata underlie the eastern part of the basin (Figures 8, 9, and 10). Water depths are less than $100 \mathrm{~m}$ throughout the basin. Those parts of North Chukchi basin that are east of the U.S.-Russia convention line of 1867 (long. $169^{\circ} \mathrm{W}$. ) and south of lat. $73^{\circ} \mathrm{N}$. lie in the Barrow Arch planning area.

Geologic and Ceographic Boundaries-- North of the basin is the Chukchi continental borderland. The southeastern boundary of North Chukchi basin is formed by a tectonic hinge line located where the dip of the Ellesmerian strata and the dip and thickness of the lower Brookian strata increase to the north and west (Grantz and May, 1984a). At lat. $72^{\circ}$ N., North Chukchi basin's eastern boundary lies at about long. $164^{\circ} \mathrm{W}$; farther north, the basin's eastern boundary probably lies along the Chukchi-Northwind fracture zone (long. $\left.161^{\circ} \mathrm{W}.\right)$. Canada Basin lies northeast of North Chukchi basin.

Basin Shape-- The basin has an asymmetric north-south cross section, open and deeper to the north.

Structural Geology-- Listric normal faults cut lower Brookian and, in places, pre-Brookian strata. They parallel the shelf break and hinge zone, trending east-west in the southern part of the basin and northeast-southwest in the eastern part of the basin. Along with antithetic faults, the listric normal faults bound back-rotated fault blocks (Grantz and others, 1982b; Grantz and May, 1984a). Listric normal faulting was probably induced by crustal stretching related to initiation of sea-floor spreading (Grantz and others, 1982b).

Diapirs are probably shale cored; up to $2 \mathrm{~km}$ in diameter, they form piercement structures which rise to within a few tens of meters of the seabed. Five have been recognized, but there are probably 30 to 40 in the basin. They are interpreted to originate in lower Brookian or upper El lesmerian strata (Grantz and May, 1984a).

Block faulting occurs within the basin (Grantz and others, 1976). Small normal faults and a few very low amplitude folds are present (Grantz and May, 


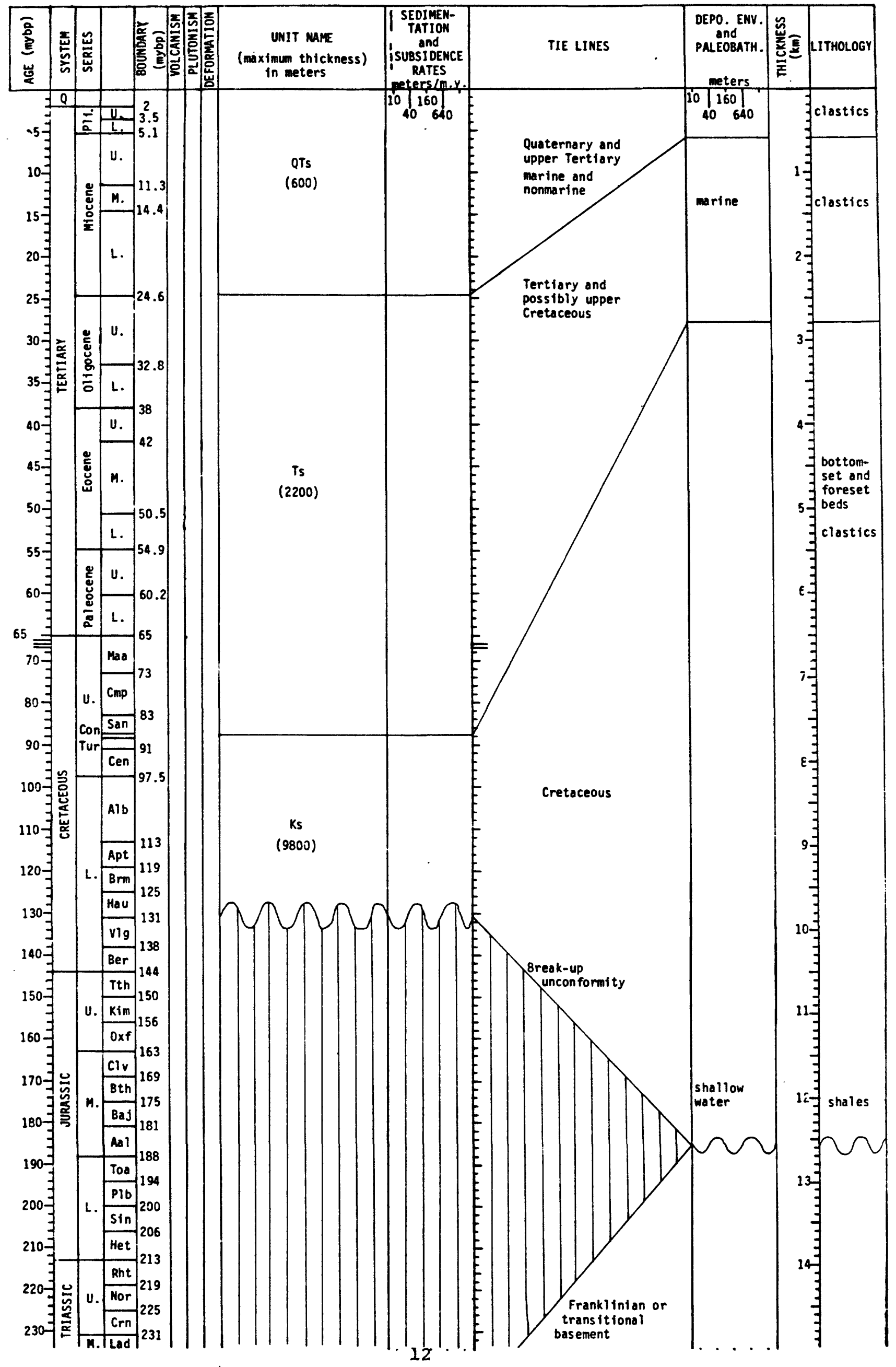


Tertiory and Crefoceous sedimentery recks, slightly to moder ot ely deformed

Cretoceous sedimentory recks, strongly deformed

E

Elleamerion sequence

Erz

Frosklinien sequence

AB:

Perched ecoustic besement of Merald arch ollochithon

$$
-\pi \text { - El }
$$

North limit of >0.1 eccond (two-woy time) of Ellesmerien strata

$$
\text { i }
$$

Propoed oil and ans leose sole nos 85

$$
\text { Boundery between oreas of Herald orch }
$$
$V_{p}=<4 \mathrm{Km} / \mathrm{sec}$ (to North) and $>4 \mathrm{Km} / \mathrm{sec}$ (to south)

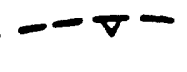

Thust foul?

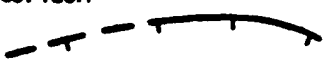

Normal fouly. Hochures on downthrown ride
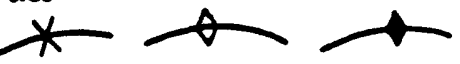

Syelin

Anticline

Arch

2

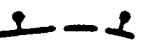

Teetenic hinge line

NORTH CHUKCHI BASIN

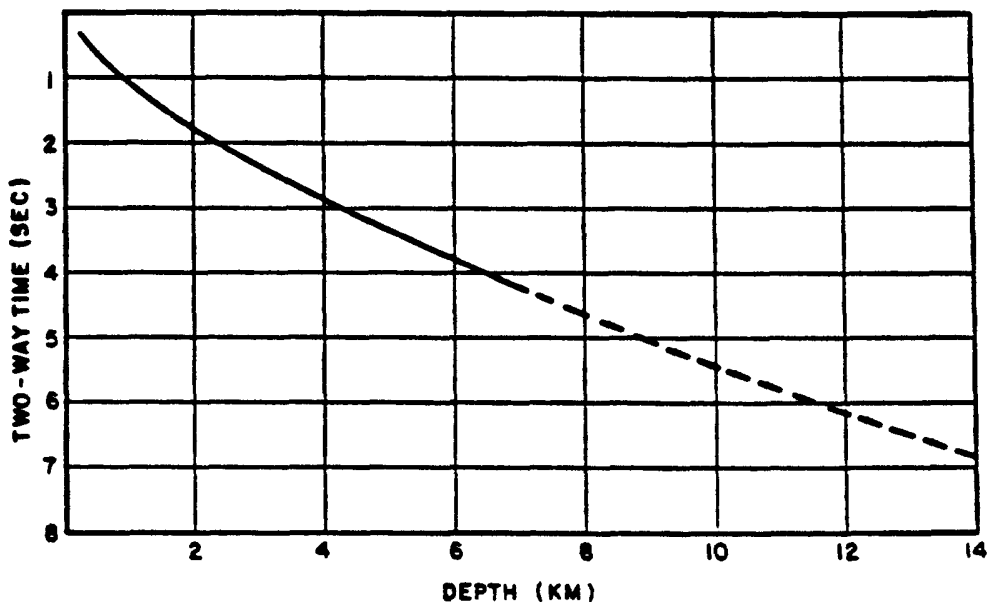

CHUKCHI SHELF

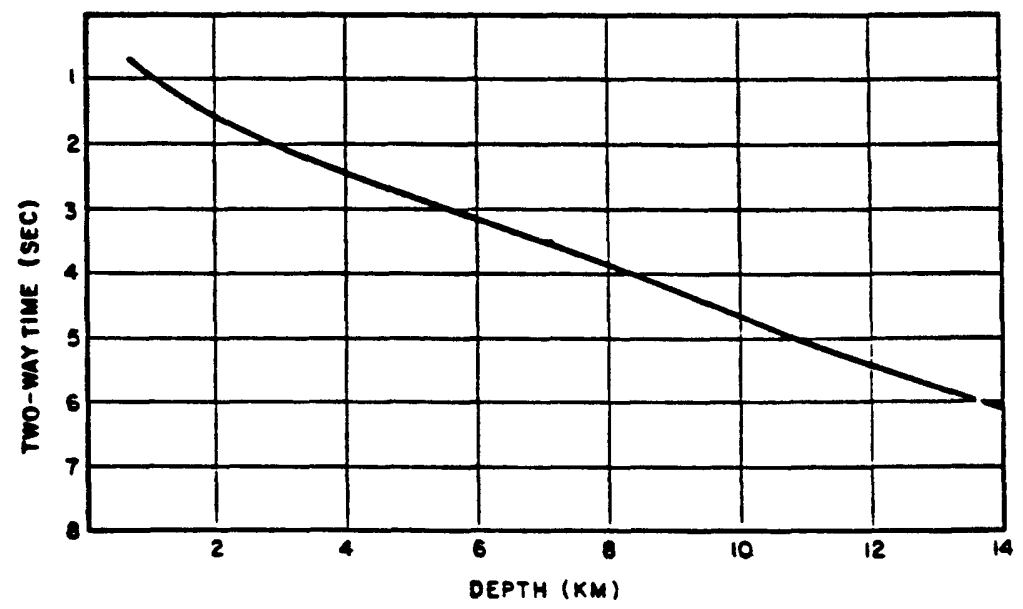

Figure 8. Explanation of map symbols in Figure 9 and plots of average seismic-reflection time as a function of depth for the Chukchi shelf and North Chukchi basin. 


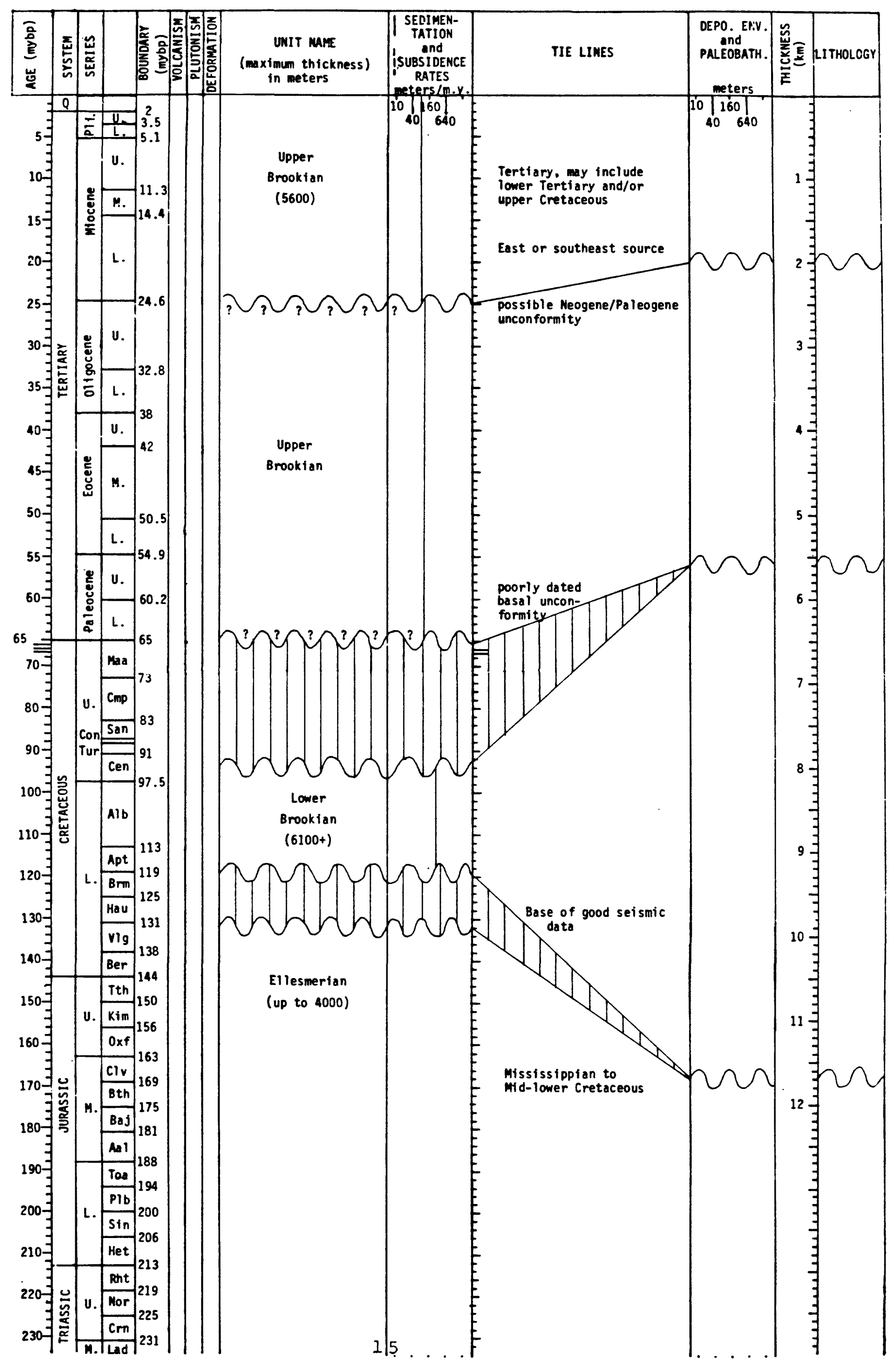


1984a).

In the southern part of the basin the strata dip to the north as much as 15 degrees, dips decrease to less than one degree farther north.

Basement-- Oceanic or thinned continental crust underlies the basin (Grantz and others, 1981). Acoustic basement is pre-Ellesmerian but may not be typical of the Franklinian sequence (Grantz and others, 1982b).

Basin Type- North Chukchi basin is a passive margin basin that originally formed as a rift basin. Two rifting events, one in late Neocomian (ca. 125-130 Ma) and the other in the latest Cretaceous or earliest Tertiary (ca. $65 \mathrm{Ma}$ ) resulted in the formation of a hinge line along the basin's southeastern margin. The basin fill prograded northward from the edge of the Arctic Platform into the deep basin.

Prominent Seianic Borizons-- As many as four stratigraphic packets are present (Figure 10); these probably represent Neogene, Paleogene, Cretaceous, and pre-Cretacous units (Grantz and others, 1981).

Magnetics-- A discussion of paleomagnetic results for the Brooks Range and Arctic Slope appears in Newman and others (1979).

Petroleum Geology-- Marine source beds are inferred to be present in the Brookian sequence (Grantz and May, 1984a). Strong seismic reflectors in the Brookian sequence are suggestive of sandstone and possibly conglomerate beds that may be potential reservoirs. Listric normal faults and rotated fault blocks in the lower Brookian sequence are overlain by either (1) a seismic unit containig relatively weak reflectors (fine-grained clastic strata?) or (2) the base of the upper Brookian unconformity; in both cases there is potential for seal and source beds adjacent to reservoir beds. Favorable trap/seal/reservoir/source relationships may be associated with shale diapirs.

No thermal data is available from the basin. However, several thermal models based on analogies with other rift basins have been proposed by Grantz and May (1984b), and all predict large volumes of Brookian strata lie within the oil generation window.

Mape and Other Illustrations-- Maps showing the location of the basin and basin structure appear with stratigraphic columns and seismic profiles in Grantz and others, $1982 \mathrm{~b}$. Grantz, Holmes, and Kososki (1976) and Grantz and May (1984b) present seismic profiles from North Chukchi basin. A cross section based on wells in the National Petroleum Reserve in Alaska (NPRA), located $200 \mathrm{~km}$ to the east, is presented in Grantz and May (1984a).

Degree of Coverage-- Both multichannel and high-resolution seismic grids with $50 \mathrm{~km}$ line spacing, some single-channel seismic data, and several seismic refraction lines cover the basin. Well data is available from onshore wells in NPRA.

other Information-North Chukchi basin is inferred to contain substantially or dominantly marine rocks (Grantz and others, 1982b).

References-- For more detailed information see Grantz and others 1982b; Grantz, Eittreim, and Whitney, 1981; Grantz, Holmes, and Kososki, 1976; Grantz, Eittreim, and Dinter, 1979; Molenaar, 1983; Ruppel and McHendrie, 1976, and Grantz and May, 1984a, 1984b.

SOOTR ChUKCBI BASIN AND THB ALASTAN MORTH SLOPE

Ceneral Information-- Located between lat. $68^{\circ}$ and $72^{\circ} \mathrm{N}$. and between long. $140^{\circ}$ and $170^{\circ} \mathrm{W}$, the South Chukchi basin and Alaska North Slope have a combined area of more than 240,000 square kilometers, 75,000 of which lie offshore. The offshore area north of Berald-Wrangel arch, south of North Chukchi basin, and south of Barrow arch is referred to here as South Chukchi basin (Plate 1) and is treated as an offshore continuation of the North 
Slope. In places the sedimentary sections of South Chukchi basin and the North slope include more than $7 \mathrm{~km}$ of rocks of the Brookian sequence (Jurassic and younger), the Cretaceous sequence alone may be $7 \mathrm{~km}$ thick. In addition, 4 to $8 \mathrm{~km}$ of sedimentary rocks of the Eo-Ellesmerian (Jurassic and early Cretaceous; Barrovian sequence of Carman and Hardwick, 1983) and Ellesmerian sequences are locally present.

Geologic and Gographic Boundaries-- Barrow Arch forms the northern boundary of the province, older strata onlap the arch and younger strata overstep it. North Chukchi basin lies to the northwest. In the west, offshore, thrust faults of the Herald fault zone bound the province. Thrust faults and folds of the Brooks Range form the southern boundary onshore.

In the northeast, the basin narrows toward the Alaska-canada border as the Brooks Range and the coast (Barrow Arch) converge. The thick Tertiary section there is known variously as Sagavanirktok, Camden, or Umiat basin. This Tertiary section extends offshore to form the progradational sediment prism of Kaktovik basin.

Basin Shape-- The North slope is elongate in an east-west direction (Plate 1). The cretaceous sequence is thickens to the south. The main Tertiary depocenter is in the northeast.

structural caolooy-- East-west trending foreland folds occur in the southern part of the area. These folds are 50 to $100 \mathrm{~km}$ long, with wavelengths of 20 to $25 \mathrm{~km}$ and amplitudes to $1.2 \mathrm{~km}$ (Grantz and others, 1976). On the Chukchi coast amplitude and tightness of folding (dips range from 1 to 15 degrees) increase southward from Icy Cape. Detachment is inferred to be in the Albian Torok shale (Grantz and others, 1981). The folds are associated with north verging thrust faults and incipient core diapirism. Deformation that resulted in the formation of foreland folds probably occurred in the Late cretaceous or early Tertiary (Laramide orogeny?). North of the zone of folding regional dips are to the south.

Basement-- Acoustic basement is in the Ellesmerian sequence, except near Barrow Arch where seismic penetrates to the top of the Franklinian sequence (Grantz and others, 1976). Crustal basement is continental, primarily rocks of the Franklinian sequence.

Basin Type-- The basin is a southward-deepening asymmetric foreland basin or foredeep. Colville foredeep is underlain by rocks of Ellesmerian age (Mississippian thru Jurassic) that are part of the Arctic Alaska basin, an intracratonic basin.

Stratigraphy-- (Figures 11, 12, 13, 14, and 15) The source area for sediment filling colville foredeep lay to the south. Prior to the Jurassic (Ellesmerian time) the source was probably to the north. Late cretaceous and Tertiary nonmarine sandstones and conglomerates form the thickest sequences of coarse-grained units. Cretaceous units are thickest in the south and thin to the north. Pro-delta and intradelta deposits overlie deep-marine units.

Volcanic rocks in the basin include Middle Jurassic tuffs and Turonian $(90 \mathrm{Ma})$ ash beds in the seabee Formation. Plutonic rocks are represented by Jurassic diabase in NPRA.

Prominent Selemic Borizons-- Many horizons have been mapped within the NPRA (See Bruynzeel and others, 1982) and in a large area surrounding Prudhoe Bay (See U.S. Geological Survey Misc. File Map Series MF-928). Prominent horizons include the base of the Tertiary and the Lower Cretaceous regional unconformity.

Gravity-- See article by May (1985) and Ostenso (1968).

pagnetics-- Paleomagnetics of northern Alaska are discussed by Newman and others (1979). 


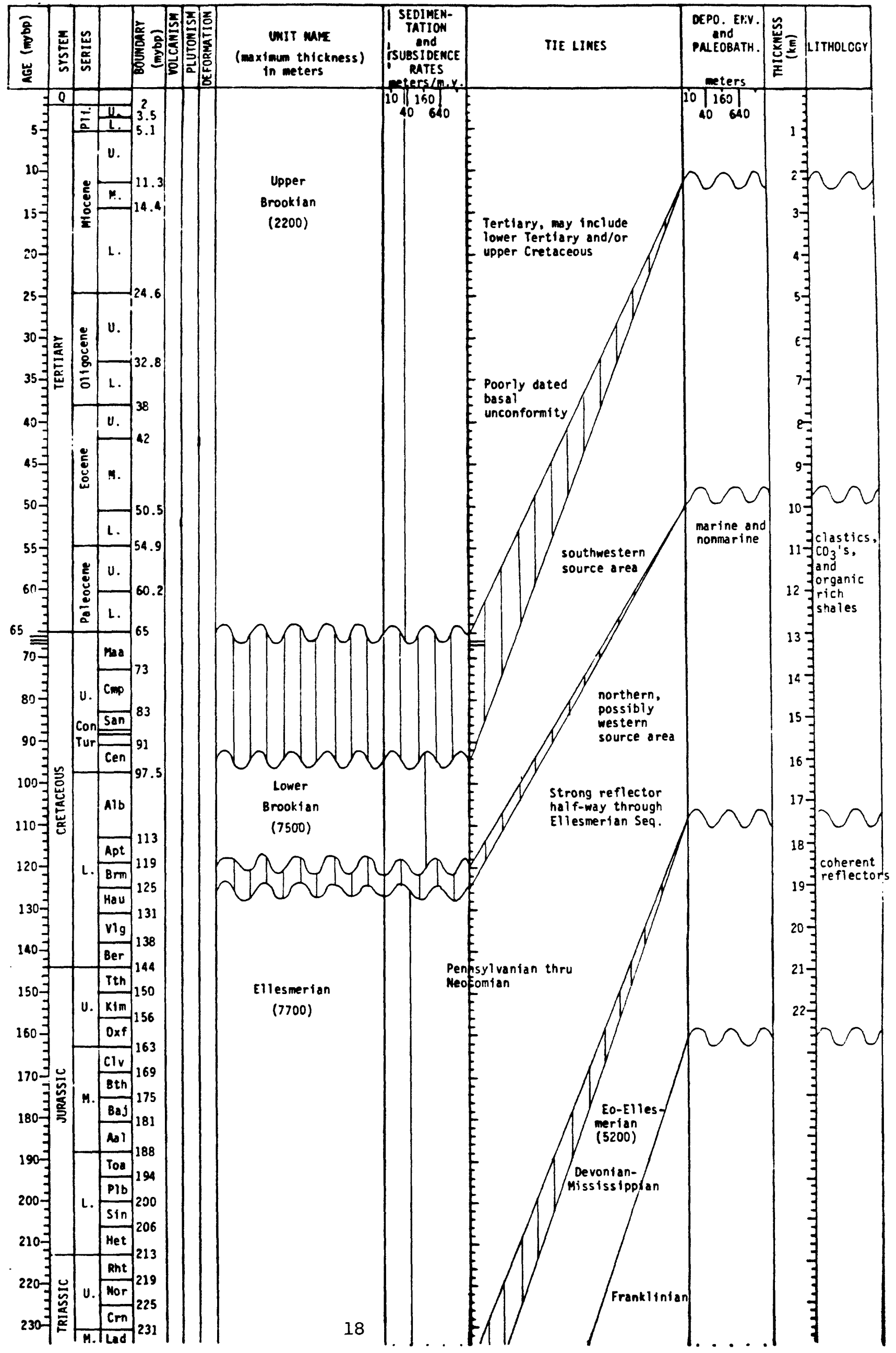




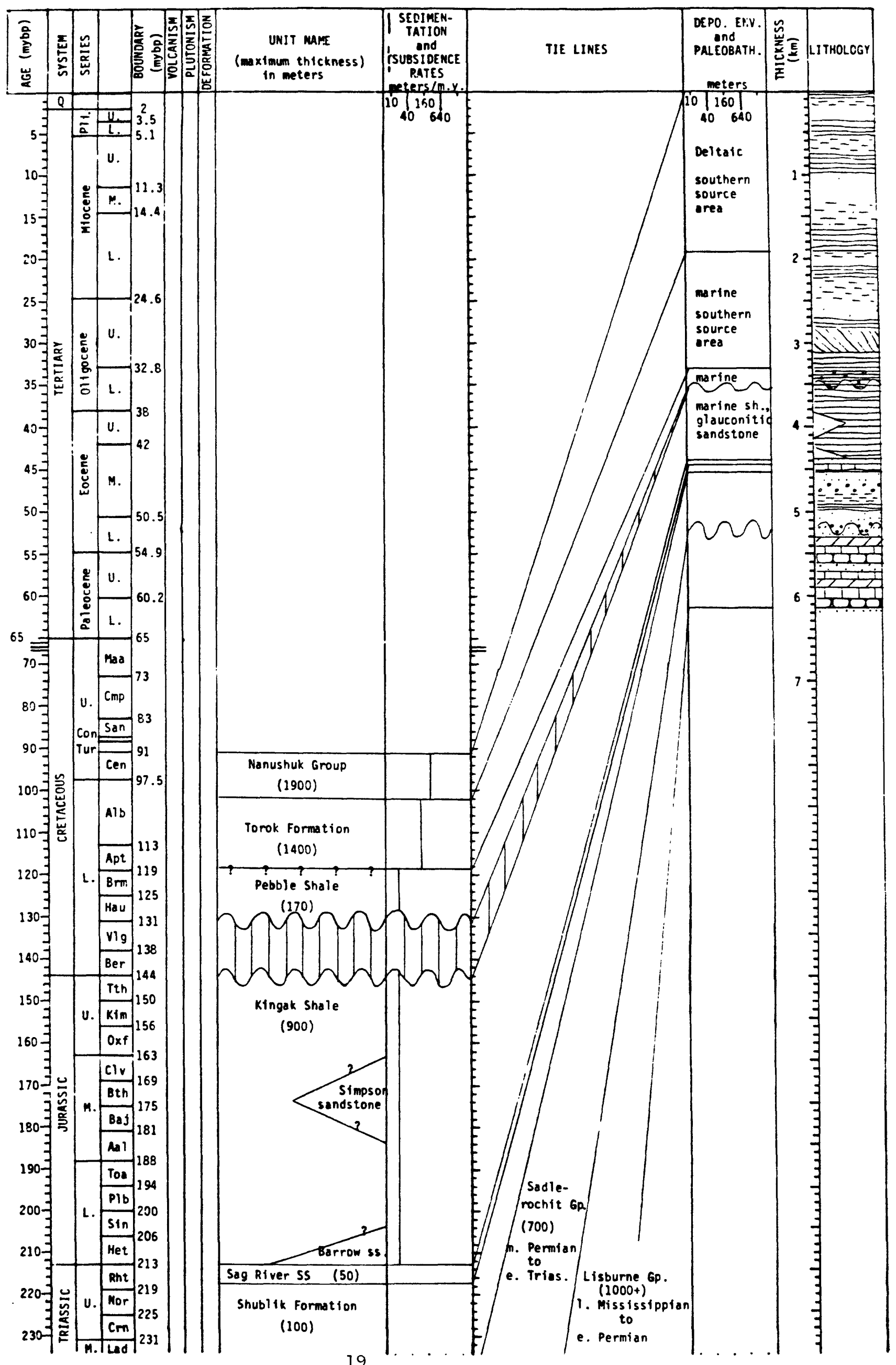


Data from Grantz and others, 1981; North Slope Biostrat. chart, 1981

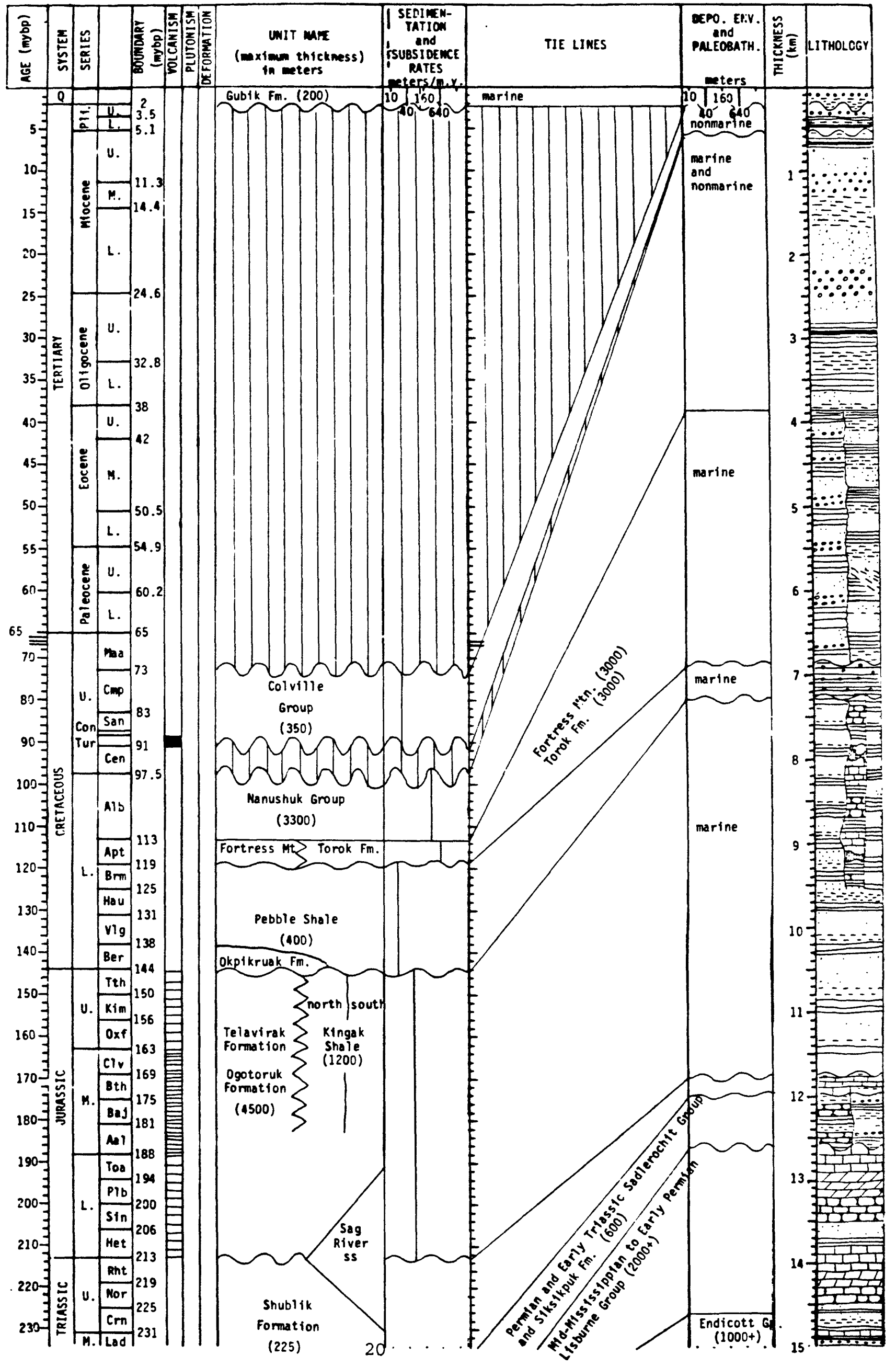


Data from Grantz and others, 1981;

Holenaar. 1983; Biostrat. Cht . 1981

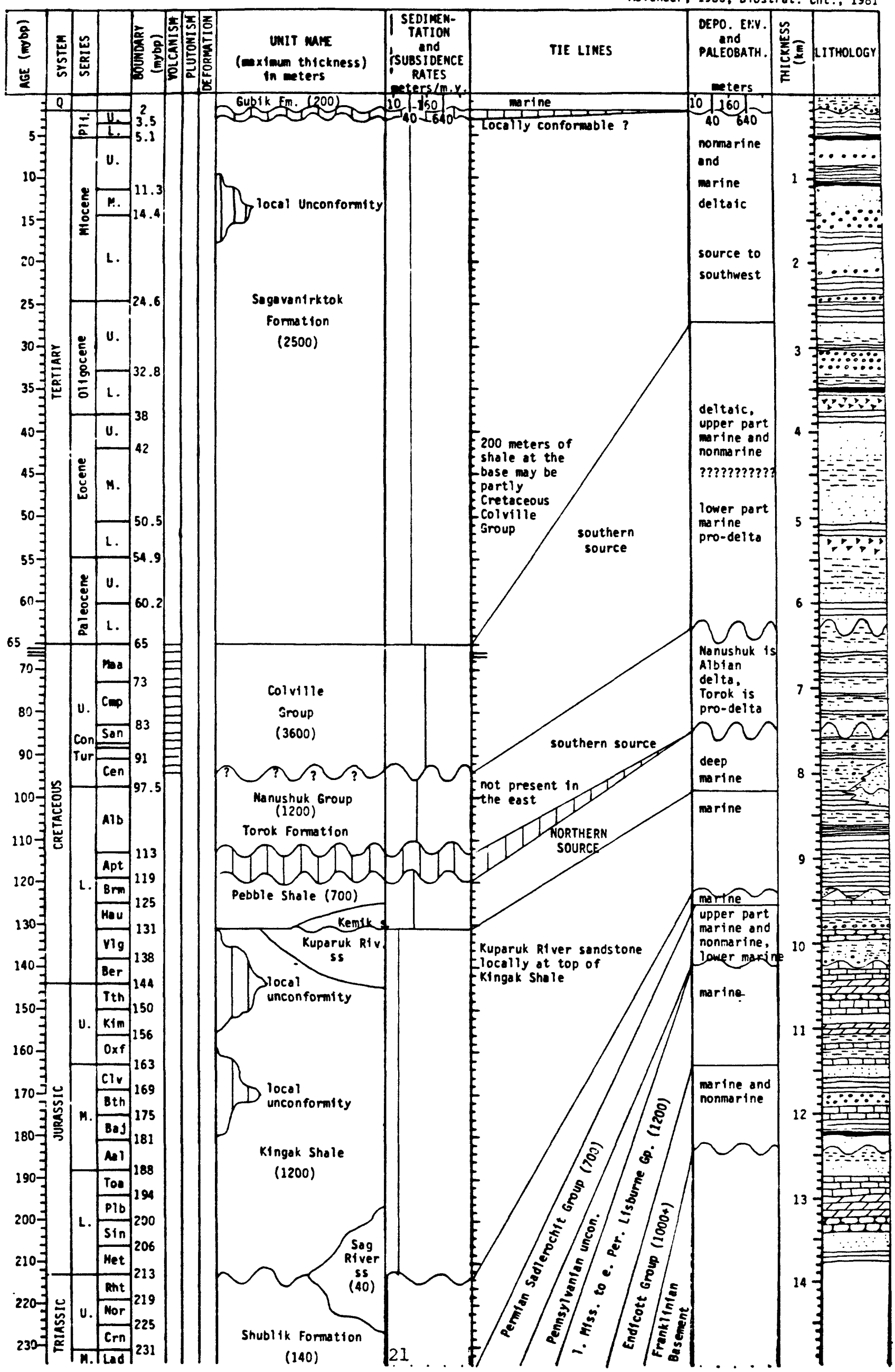




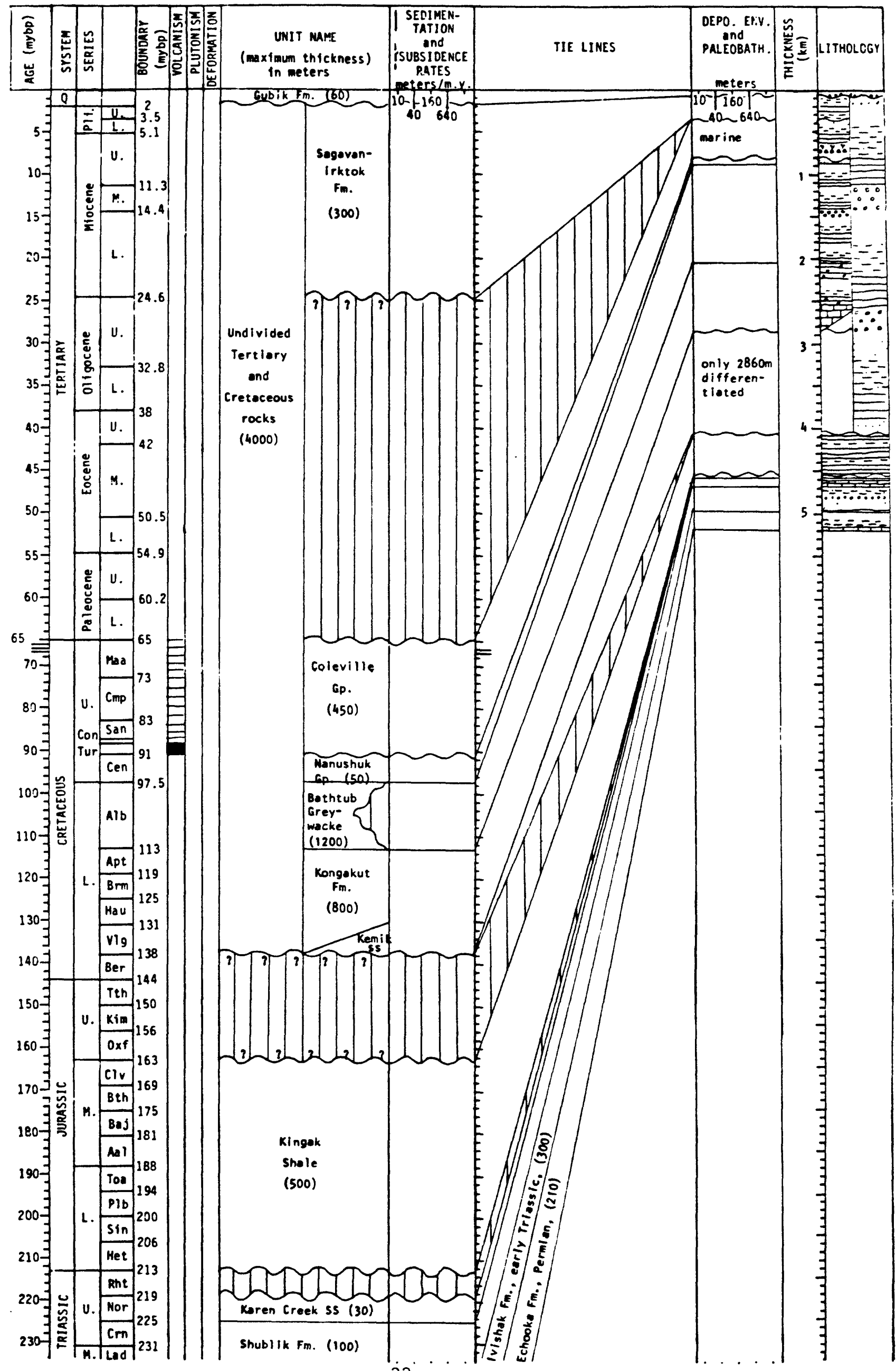


Petroleum Geology-- on the North Slope, the geothermal gradient ranges from 25 to $40^{\circ} \mathrm{C} / \mathrm{km}$ and is highest near Prudhoe Bay (Tailleur and Engwicht, $1978)$.

Prudhoe Bay and Kuparuk River hydrocarbons accumulated in combined stratigraphic and structural traps. Closure is provided by structural dip, an unconformity, and high-angle faults. Cretaceous shales (source rocks?) commonly seal the reservoirs and are present in large amounts south, east, and possibly north of the two fields. Other source beds include Triassic and Jurassic shales (Carman and Hardwick, 1983; Jones and Speers, 1976). Oil and gas bearing rocks are discussed in Jones and Speers (1976).

Maps and Other Illustrations-- Location maps and stratigraphic columns are included in Grantz and others, 1981. Isopach and structure-contour maps, as well as seismic profiles, cross sections, and stratigraphic columns, appear in Bruynzeel and others, 1982. Isopach, structure contour, location, and geothermal gradient maps are included in U.S. Geological Survey Misc. File Map Series MF-928. See also the Alaskan North Slope Generalized Subsurface Biostratigraphic Chart (Biostratigraphics, 1981).

Degree of Coverage-- This large area ranges from well covered near Prudhoe Bay to moderately well covered in NPRA to poorly covered in the Alaska National Wildlife Refuge.

Other Information-- Nonmarine Cretaceous and Tertiary strata crop out along the northern side of the basin.

The basin connects with North Chukchi basin over Barrow Arch in the northwest and with the Beaufort Shelf (Nukum and Kaktovik basins) in the northeast.

References-- For more detailed information see Grantz and others, 1976, 1981; Molenaar, 1983; Carman and Hardwick, 1983; Jones and Speers, 1976; Newman and others, 1979; Ostenso, 1968; Bruynzeel and others, 1982; U.S. Geological Survey Misc. Field Map Series MF-928; and Biostratigraphics, 1981.

\section{HOPE BASIN}

General Information-- Hope basin is located at lat. $66^{\circ} 30^{\circ}$ to $79^{\circ} \mathrm{N}$. , long. $165^{\circ}$ to $172^{\circ} \mathrm{W}$. It has an area in excess of 63,000 square $\mathrm{km}$. The maximum thickness of the basin fill is $5.6 \mathrm{~km}$ (Grantz and May, 1984a). Sedimentary rocks filling Hope basin are mainly Tertiary and younger, but the basin may include strata of Late cretaceous age. Water depths are less than $100 \mathrm{~m}$ throughout the area. Most of the basin lies in the Hope planning area, the northeastern corner of the basin (east of long $169^{\circ} \mathrm{W}$. and north of point Hope) is part of the Barrow Arch planning area.

Geologic and Goographic Boundaries-- Herald Arch, an uplifted basement arch extending northwest from Cape Lisburne, and thrust faults of the Herald fault zone form the northern boundary of the basin. Wrangel Arch, a northwestern extension of Herald Arch, forms the northwest boundary of the basin. In the southwest, sedimentary rocks onlap basement at the chukotsk Peninsula (U.S.S.R.). Acoustic basement shallows south of the basin at Kotzebue Arch where the basin fill onlaps older high-velocity rocks of the Seward and Chukotsk Peninsulas. Selawik lowland, an onshore extension of the basin, lies along the northern side of seward Peninsula and may connect with the Cretaceous Kobuk basin to the east. Down-to-basin normal faults parallel the coast on the eastern side of the basin adjacent to the DeLong Mountains. The Lisburne Hills uplift lies northeast of Hope basin.

Basin Shape- Hope basin is elongate in an east-west direction (Figure 16); the basin is deeper in the east, with a more steeply dipping basement surface to the north. During the Tertiary the depocenter migrated from the 


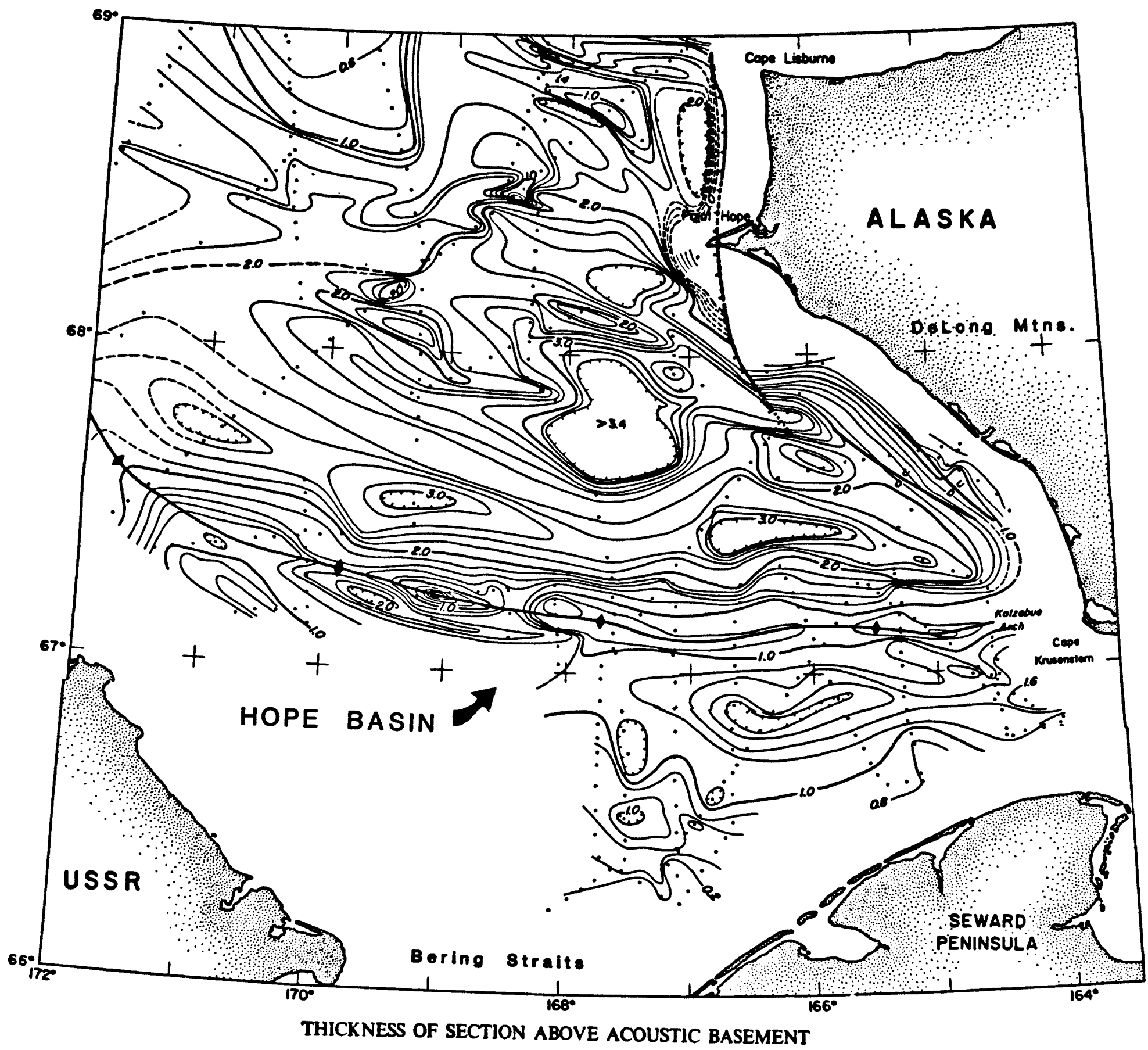

Figure 16. Isopach map of Hope basin. Contour interval 0.2 kilometers. From Eittreim and others, 1978. 
south or southwest to the north or northeast through the Tertiary. In the Neogene the depocenter was north of Rotzebue Arch, northwest of Cape Krusenstern and adjacent to the DeLong Mountains. The main depocenter during the Paleogene (possibly Late Cretaceous) was west of Point Hope, sedimentary rocks were also deposited south of what is now Kotzebue Arch. Paleogene rocks are more uniformly distributed than Neogene rocks (Grantz and others, 1982b). A series of buried basement ridges divide Hope basin into elongate troughs or subbasins (Eittreim and others, 1977).

Structural Ceology-- Eastward-trending elongate troughs and ridges occur throughout the basin. Some ridges are asymmetrical, resembling rotated fault blocks, others are symmetrical and seem to be horsts.

Kotzebue Arch is a major east-west trending mid-Tertiary tectonic warp in the southern part of the basin. It is older than seismic horizon " $K$ " and may connect with the southern Brooks Range (Baird Mountains, Igichuk Hills). A down-to-the-north normal fault with up to $2.5 \mathrm{~km}$ displacement forms the arch's northern flank, creating an east-west trending half graben. The arch formed the hingeline for subsidence of the Neogene basin. Active uplift of the ridge took place in the late Tertiary (Eittriem and others, 1977).

There are small, deeply buried, east-west trending anticlines that are older than (or coevil with) the formation of Rotzebue Arch. Some of these seem to be offshore extensions of topographic features in western Alaska (Eittreim and others, 1977).

Thrust faults, high-angle reverse faults, and high-angle normal faults are all present in Hope basin (Grantz and others, 1982b).

Basement-- The basin formed on continental crust. Some basement ridges are offshore extensions of topographic features in western Alaska. Seismic reflections show strong basement relief, faulting, and warping (Grantz and others, 1982b). Acoustic basement is probably strongly deformed lower Cretaceous and older rocks of the Brooks Range orogen (Grantz and others, 1981).

Basin Type- Hope basin is an extensional (north-south extension) intracontinental basin (Grantz and others, 1981) analogous to Norton basin (Grantz and others, 1982b).

Stratigraphy-- The major source area for sediment filling the basin is probably east of the basin (Alaska); the amount of sediment derived from the west (Siberia) is unknown. Sediment distribution is controlled by basement ridges (Eittreim and others, 1977).

Coarse-grained units were penetrated in two wells at Kotzebue sound at 600 and $1100 \mathrm{~m}$ (Eittreim and others, 1977). Below $1100 \mathrm{~m}$ the occurrence of coarse-grained units increased in both wells.

In the area north of Kotzebue Arch reflectors younger than seismic horizon " $K$ " diverge to the north.

Basaltic volcanism on the Seward Peninsula began in the late Miocene and continued into the Pliocene and Pleistocene.

Deformation that resulted in the formation of Rotzebue arch and related structures took place in the middle Tertiary. Active uplift continued in the late late Tertiary (Eittreim and others, 1977).

Prominent Seigmic Borizons-- Reflector " $K$ " is of unknown age but is probably late Tertiary and possibly represents the Paleogene-Neogene boundary (Figure 17). It divides the basin fill into two sequences and may be an unconformity. Reflections in the upper sequence show continuous bedding and no channeling, this sequence is inferred to have been deposited in a quiet marine (estuarine or shelf) environment. The acoustic basement surface forms another prominent seismic horizon. 
Data from Eittreim and others, 1977; 1978; Grantz and May, 1984a.

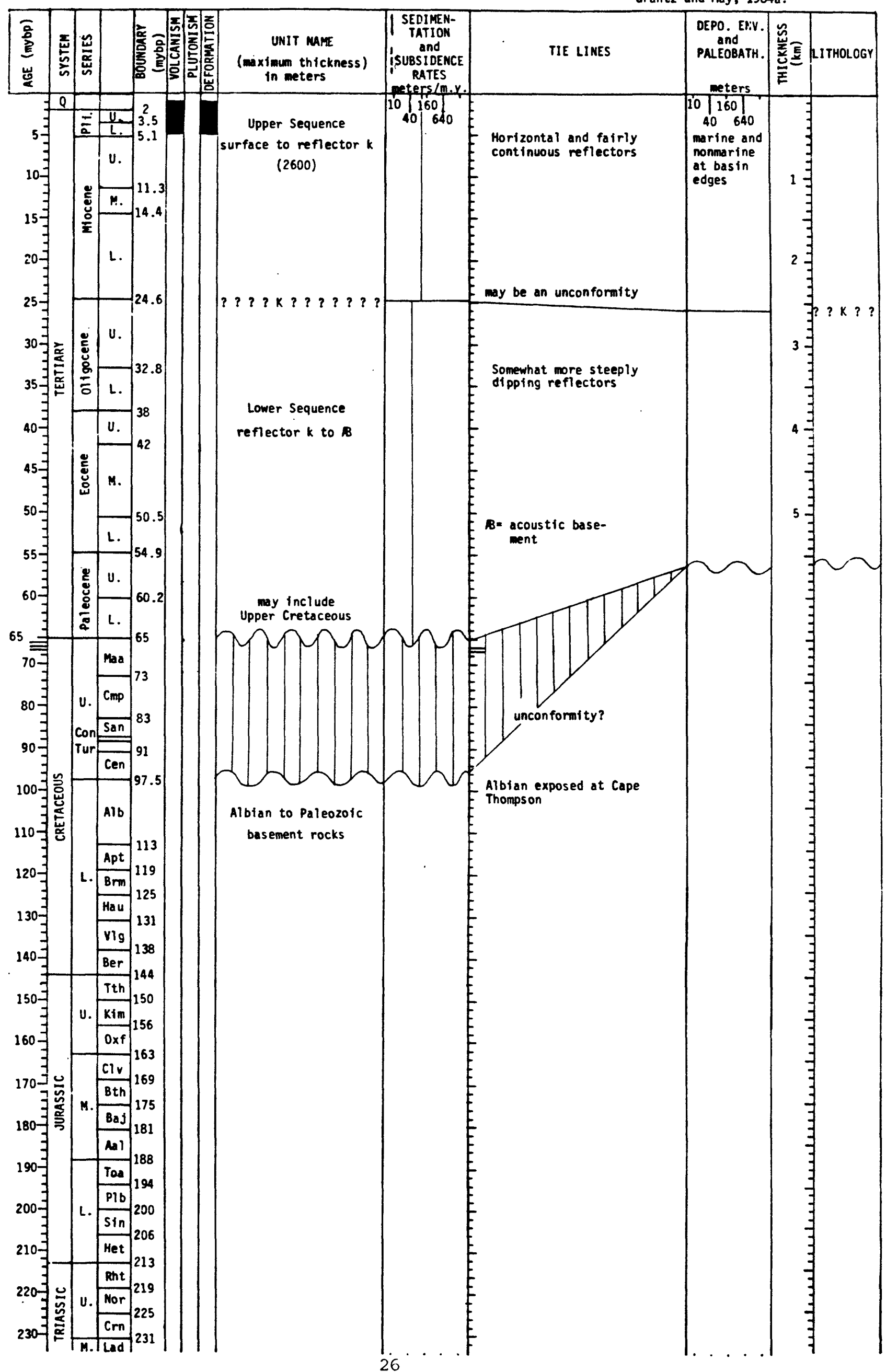


Gravity-- A positive anomaly has been recognized along Kotzebue Arch (Barnes, 1976; Ostenso, 1968).

Petroleu Ceology-- The geothermal gradient has been inferred to be 35 to $40^{\circ} \mathrm{C} / \mathrm{km}$, analogous to Norton basin. Source rocks may be gas prone.

Maps and Other Illustrations-- Location and isopach maps, along with seismic profiles and cross sections, appear in Eittreim and others, 1977. Cross sections and seismic profiles are included in Grantz and others, 1976.

Degree of coverage-- A single-channel seismic grid with $25 \mathrm{~km}$ spacing and four seismic refraction lines cover the basin. There are two wells onshore in the southeastern part of the basin.

Other Information-- Nonmarine rocks are prominent (possibly dominant) in marginal outcrops and Rotzebue test wells. Tertiary marine faunas were, however, able to migrate across the Bering Straits.

References-- For more information see Grantz and others, 1976, 1979, 1981, 1982b; Eittreim and others, 1977, 1978; Barnes, 1976; Ostenso, 1968; and Grantz and May, 1984a, b.

\section{MORTON BASIN}

General Information-- Norton basin has an area of 34,000 square $\mathrm{km}$. Water depths range up to $50 \mathrm{~m}$. As much as $6.5 \mathrm{~km}$ of Eocene (Paleocene or Cretaceous?) and younger sedimentary rocks fill the basin. It forms the Norton Basin planning area.

Geologic and Ceographic Boundaries-- The basin lies south and southwest of Seward Peninsula (Figure 18). Along the western part of the peninsula the basin fill onlaps a shallow basement platform. To the east lies the east-west trending North Boundary fault, a down-to-basin normal fault with up to $4 \mathrm{~km}$ of offset. The Bering straits (shallow basement), Chukotsk Peninsula (basement outcrops), and U.S. - Russia convention line lie northwest and west of Norton basin. Saint Lawrence Island, and the north-northwest trending South Boundary fault--a down-to-basin normal fault with up to $2.5 \mathrm{~km}$ throw--lie southwest of the basin. South of the basin are the Yukon Delta, Bering Shelf, and the 1 to $2 \mathrm{~km}$ thick sedimentary section of Saint Matthew basin. East and southeast of the basin is a possible crustal suture where Precambrian rocks are in fault contact with Cretaceous sedimentary rocks of the Lower Yukon basin (YukonKoyukuk province).

Basin Shape-- The basin is elongate in an east-west direction, $350 \mathrm{~km}$ long by 50 to $120 \mathrm{~km}$ wide. It is divided into three structural areas: (1) an area with basin fill thinner than $2 \mathrm{~km}$ that is located north of saint Lawrence Island and west of long. $168^{\circ}$ W., (2) Saint Lawrence subbasin, located south and west of Yukon Horst, contains up to $5 \mathrm{~km}$ of sedimentary fill, and (3) Stuart subbasin, located north and east of Yukon Horst, contains up to $6.5 \mathrm{~km}$ of sedimentary fill.

Structural Geology-- Yukon Horst has up to $3 \mathrm{~km}$ of relief, the northern side of the horst is steepest and has the most relief. The horst separates the eastern part of Norton basin into saint Lawrence and Stuart subbasins. Strata overlying Yukon horst are folded. The horst probably formed early in the basin's history, preventing the movement of sediment between the two subbasins.

West of long. $168^{\circ} \mathrm{W}$. northwest-trending grabens shoal to the northwest. Northwest-trending antiforms may be anticlines or horsts.

Saint Lawrence subbasin contains northwest-trending faults that have been most active near the Yukon Delta. Drape or compaction structures form broad anticlines (with $2^{\circ}$ to $9^{\circ}$ dips on the flanks) that show decreasing relief upsection. These may overlie volcanic mounds in the basement (Fisher and 


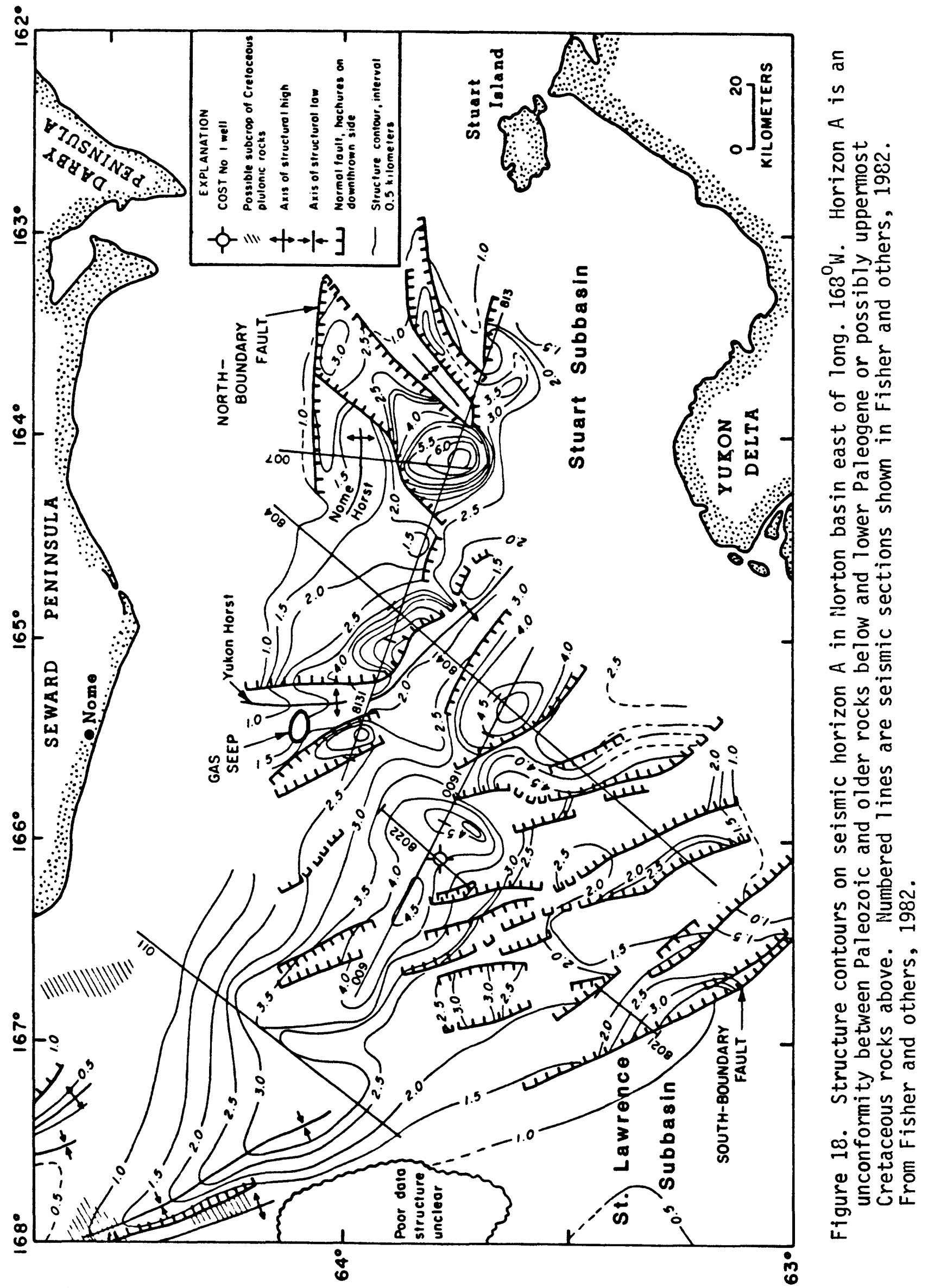


others, 1982).

Stuart subbasin includes the east-west trending Nome horst and the eastwest trending North Boundary fault--a down-to-the-south normal fault that is located along the subbasin's northern side. Other structures have northeast trends.

Few onshore strutures extend offshore. Major faults were most active early in the basin's history. In general, dips shallow upsection.

Basement-- Precambrian crystalline rocks and Paleozoic rocks (including carbonates) underlie most of the basin. Cretaceous rocks of the Lower Yukon basin (Yukon-Koyukuk province) may underlie the southwestern part of the basin near the Yukon Delta. Basement was metamorphosed and deformed in the Late Jurassic and Cretaceous, but basement structure observed today probably resulted from an early Tertiary event. Cretaceous siliceous plutons (magnetic) and possibly calc-alkaline plutons (non-magnetic) underlie parts of the northwestern Bering Sea including Norton basin (Fisher and others, 1982).

Basin Type- During the Neogene the basin underwent isostatic regional subsidence. In the Paleogene it was an extensional rift basin which initially subsided by block faulting.

stratigraphy- The metamorphic terrane on seward peninsula has been a major source for basin-filling sediments. Coarse-grained units include Paleogene continental deposits.

In the northern Bering Sea, calc-alkaline volcanism occurred from 108 to $92 \mathrm{Ma}, 85$ to $70 \mathrm{Ma}$, and 70 to $55 \mathrm{Ma}$. Flood basalts erupted in the Miocene and Pliocene. Granitic intrustions have been dated at 110 to $85 \mathrm{Ma}$ and calcalkaline intrusions 85 to $70 \mathrm{Ma}$ (Figure 19).

Prominent Seismic Borizons-- The " $A$ " horizon of Fisher and others (1982) lies on top of the acoustic basement surface and is probably Paleozoic or older (Figure 19). A discontinuous horizon in the Paleogene section--locally an unconformity on continental deposits--is the " $B$ " horizon of Fisher and others (1982) and the "B-1" horizon of Turner and others (1983b). Throughout the basin a zone of continuous, moderately strong reflectors overlies a zone of discontinous, weak reflectors; the horizon separating these two sequences has been designated the " $C$ " horizon (Fisher and others, 1982). In Norton basin COST well no. 2, horizon $C$ occurs in the oligocene section and represents a marine transgression (Turner and others, 1983b). Horizon " $D$ " of Turner and others $(1983 \mathrm{~b})$ represents the top of a conformable sequence throughout the basin and is correlative with a late oligocene coal-sandstone sequence at the COST well. However, horizon " $D$ " of Fisher and others (1982) is interpreted as an unconformity at the base of the Pliocene or as a Bottomsimulating Reflector (BSR) produced by a density contrast associated with silica diagenesis.

Gravity-- Strength of anomalies is proprotional to basement depth (Fisher and others, 1982). A gravity map in Fisher and others (1982) shows Bouguer gravity onshore on the Seward Peninsula and free-air gravity offshore in Norton basin.

Magnetics-- Anomalies in the basin are probably associated with Cretaceous silicic plutonic rocks (Fisher and others, 1982).

Petroleu Geology- The geothermal gradient in Norton basin was estimated by Fisher $(1982)$ to be 35 to $40^{\circ} \mathrm{C} / \mathrm{km}$. The gradient in COST $\$ 1$ was $36.5^{\circ} \mathrm{C} / \mathrm{km}$ from 608 to $2745 \mathrm{~m}$ and, 36 hours after circulation ceased, was $44.5^{\circ} \mathrm{C} / \mathrm{km}$ from 2896 to $4468 \mathrm{~m}$ (Turner and others, 1983a). The gradient in cosT \$2 was $37^{\circ} \mathrm{C} / \mathrm{km}$ from 305 to $3353 \mathrm{~m}$ and, 48.5 hours after circulation ceased, was $45.6^{\circ} \mathrm{C} / \mathrm{km}$ from 3353 to $4267 \mathrm{~m}$ (Turner and others, 1983b).

Vitrinite reflectance values range from 1.88 to 3.458 in eastern Norton 


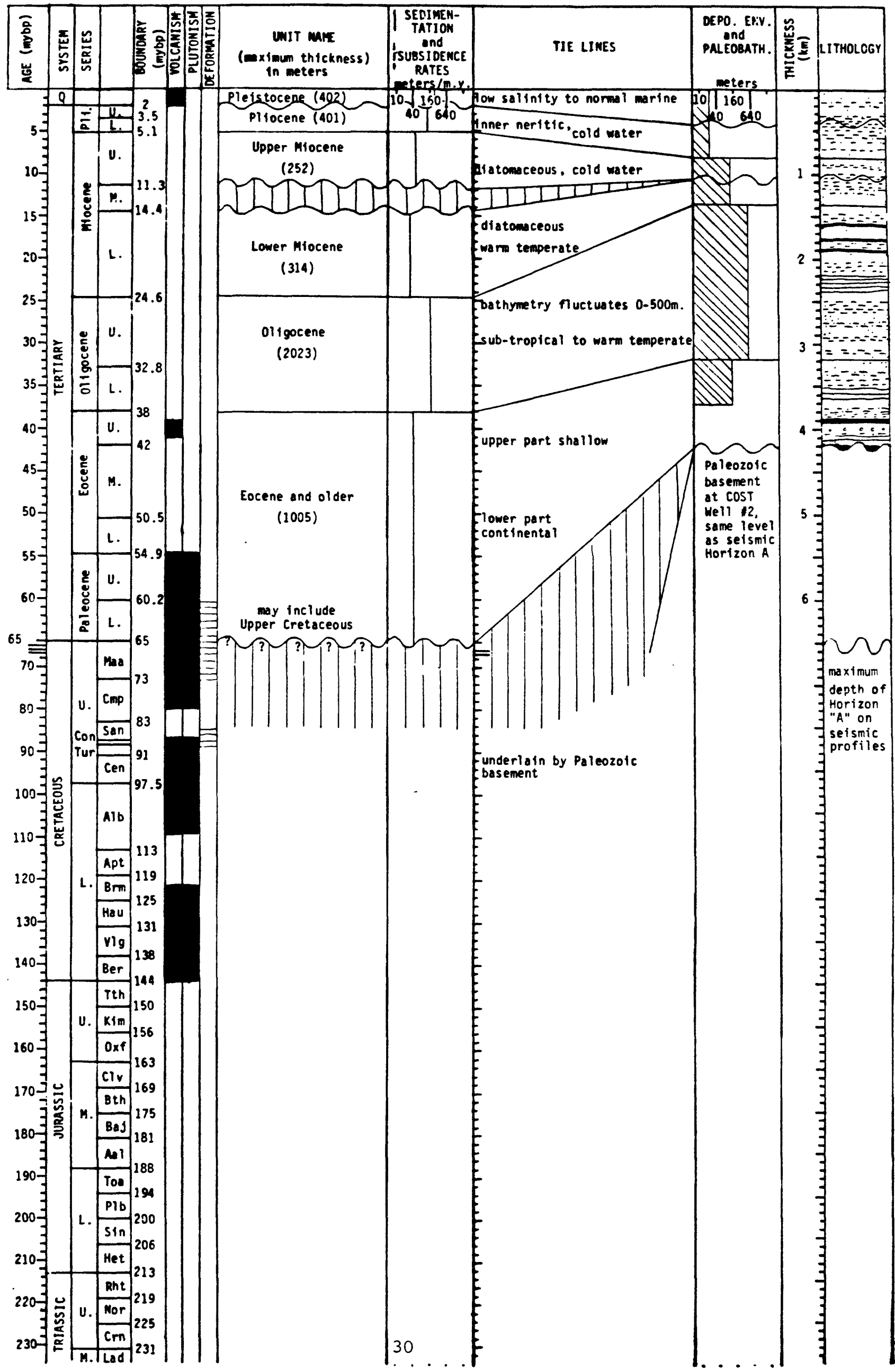


Sound, from 0.86 to 0.928 on Seward Peninsula, from 0.22 to 0.398 on saint Lawrence Island (Fisher, 1982), from 0.2 to 88 (average 0.58) in COST \#1 (Turner and others, 1983a), and from 0.3 to 1.48 (average 0.58 ) in COST \#2 (Turner and others, 1983b). Best hydrocarbon generation is associated with vitrinite reflectance values of $0.68<x<1.48$. These values were encountered between 2957 and $4206 \mathrm{~m}$ in COST \#1 (Turner and others, 1983a) and between 3261 and $4359 \mathrm{~m}$ in COST \#2 (Turner and others, 1983b).

Organic carbon in onshore rocks ranges from 0.16 to 2.18 (Fisher, 1982). Organic carbon in the COST wells ranges from 0.2 to 528 (coal beds give high values) and is commonly between 0.2 and 28. Organic matter in cosT $\$ 2$ is predominantly type III humic kerogen (Turner and others, 1983b).

Evidence for diagenesis of the basin fill includes laumontite filling voids and the possibility that Fisher and others' (1982) seismic horizon D represents a diagenetic front (opal A to opal CT?).

Numerous faults cut potential hydrocarbon migration paths in Norton basin. A gas seep has been observed on the northern end of Yukon Horst (Fisher, 1982).

Maps and other Illustrations-- Structure-contour and location maps appear along with seismic profiles in Fisher and others, 1982.

Degree of coverage-- Coverage includes two COST wells, a 24 channel seismic net and a single channel seismic net at $20 \mathrm{~km}$ spacing, and 33 seismic refraction lines.

Other Information-- Subsidence exceeded sedimentation early in the basin's history. An unconformity in the uppermost nonmarine beds (late Paleogene?) also beveled horst tops flat.

References-- For more detailed information see Fisher and others, 1982; Fisher, 1982; and Turner and others, 1983a and $b$.

\section{AWADYR BASIN}

Ceneral Information-- Anadyr basin is located at lat. $64^{\circ} \mathrm{N} .$, long. $178^{\circ} \mathrm{W}$ (Figure 20). It has a total area of 75,000 square $\mathrm{km}, 35,000$ square $\mathrm{km}$ onshore in the U.S.S.R. and 40,000 square $\mathrm{km}$ offshore. The maximum thickness of basin fill is greater than $9 \mathrm{~km}$, and is $12 \mathrm{~km}$ in Domyousik basin. Rocks in the basin are thought to be Cretaceous and younger in age. Water depths are less than $200 \mathrm{~m}$.

Ceologic and Coographic Boundaries-- North and east of the basin is the Okhotsk-Chukotsk volcanic belt, a broad bedrock high of predominantly igneous composition. In the north and northwest the Anaut uplift, a bedrock high, separates Anadyr basin from the smaller Kresta basin. To the west, Anadyr basin extends onshore into the U.S.S.R. The southern boundaries of the basin are formed by the Koryak melange belt, the Koryak Range, and Anadyr Ridge--a northwest-trending, partly igneous, faulted-bedrock high that shows gravity and magnetic anomalies and may be the offshore extension of the Roryak melange belt.

Basin Shape- The offshore part of the basin is elongate and curved, trending north-south in the eastern part (East Anadyr Trough) to northwestsoutheast in the area west of long. $177^{\circ} \mathrm{w}$. The onshore and nearshore parts of the basin trend east-west.

Structural Cology-- Anaut uplit, located at the northeast corner of the Gulf of Anadyr, is a basement uplift associated with gravity and magnetic highs. The overlying sediments are faulted.

Paleogene and older units are broadly folded in the onshore section, and are cut by reverse and normal faults. More than 50 northeast-trending anticlines occur onshore. Offshore, these ridges swing around to trend 


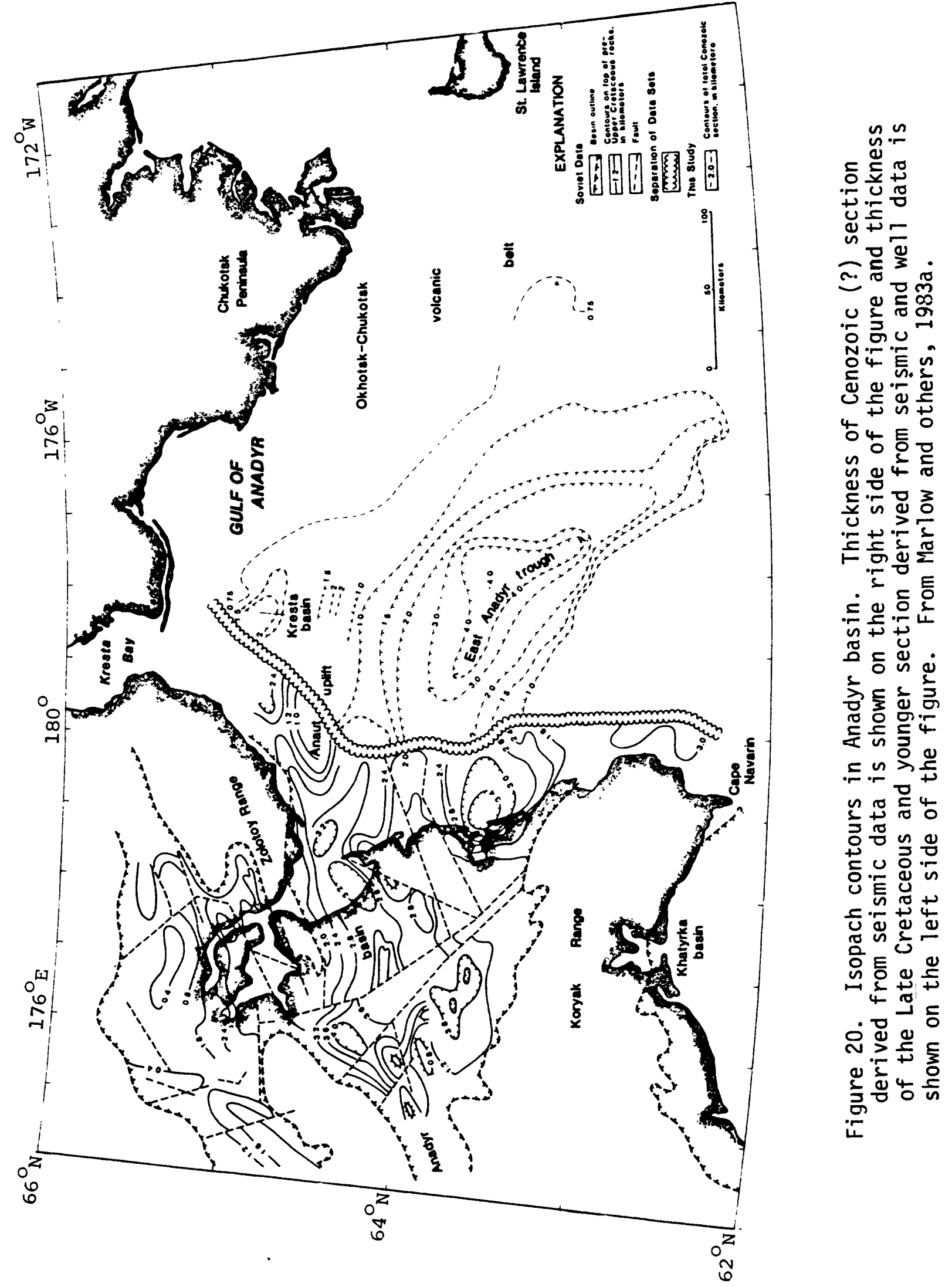


northwest.

Basement-- Onshore, economic basement is in Iower Cretaceous tuff, sandstone, andesite, and basalt beds. Acoustic basement is not well defined; terminal reflectors are not visible on some seismic profiles. Basement may be folded and broken blocks of Upper Jurassic and Lower Cretaceous rocks.

Beneath the northern parts of the basin, crustal basement is formed by the Okhotsk-Chukotsk magmatic arc. The rest of the basin is inferred to be underlain by transitional or oceanic crust.

Basin Type- Anadyr basin is a broad crustal sag, possibly a Cretaceous forearc basin.

Stratigraphy-- The source of basin filling sediment is in the Koryak and Chukotsk ranges to the north. anshore, coarse-grained units include up to 80 $m$ of high-porosity sandstone in the Miocene section (Figure 21). Some sandstone beds are lenticular.

Volcanism and plutonism include cretaceous and early Tertiary calcalkaline sequences of the Okhotsk-Chukotsk volcanic belt and diabase sills of Senonian age (88-65 Ma).

Two distinct periods of deformation include one that accompanied basin formation in the Mesozoic, concurrent with development of the okotsk-Chukotsk volcanic arc and the Roryak melange belt, and one in the late cenozoic that caused uplift near the Anaut uplift and east of Cape Navarin (Marlow and others, 1983a).

Prominent Seimic Borizons-- There are two prominent seismic horizons, alpha and beta (Figure 22). The alpha horizon underlies a sequence of $f 1$ at or gently dipping, laterally continuous reflectors and is interpreted as the Neogene-Paleogene boundary. Velocities at the alpha horizon range from 3590 to $3950 \mathrm{~m} / \mathrm{sec}$. The beta horizon underlies a more steeply dipping or folded sequence of short, discontinuous reflectors, and is interpreted as the Cenozoic-Mesozoic boundary. Velocities at the beta horizon range from 5340 to $4780 \mathrm{~m} / \mathrm{sec}$. Alpha and beta are iso-velocity horizons and may be time transgressive (Marlow and others, 1983a). In general, at a given depth, seismic velocities onshore are higher than seismic velocities offshore.

Gravity-- See Marlow and others (1983a) for a free-air gravity map.

Mgnetics- See Marlow and others (1983a) for magnetic profiles and a discussion of magnetics.

petroleu Geology-- Vitrinite reflectance values show a weak to moderate thermal history (Mclean, 1979a). Potential oil and gas bearing rocks (Miocene sandstone) show up to 268 effective porosity and 560 md permeablility. Gas shows occur in cretaceous and Miocene sandstone beds and in Eocene and Oligocene rocks onshore.

maps and Oher Illustrations- see Marlow and others (1983a) for location, isopach, structure, and thickness maps and also for seismic profiles, line drawings of profiles, and cross sections. structure-contour maps and stratigraphic columns appear in McLean, 1979a.

Degree of coverage-- Coverage includes thirty soviet wells onshore, 1800 $\mathrm{km}$ of offshore geophysical data, 17 seismic refraction lines offshore, and line drawings of $300 \mathrm{~km}$ of soviet geophysical data.

other Information-- The history of Anadyr basin is similar to that of Navarin basin.

oomyousik basin, lat. $72^{\circ} 20^{\prime} \mathrm{N}$. , long. $178^{\circ} \mathrm{W}$. , is a normal-fault-bound basin containing more than $12 \mathrm{~km}$ of southeast-dipping post-beta-horizon fill.

References-- For more information see Marlow and others, 1983a; Cooper and others, 1979; and McLean, 1979a. 


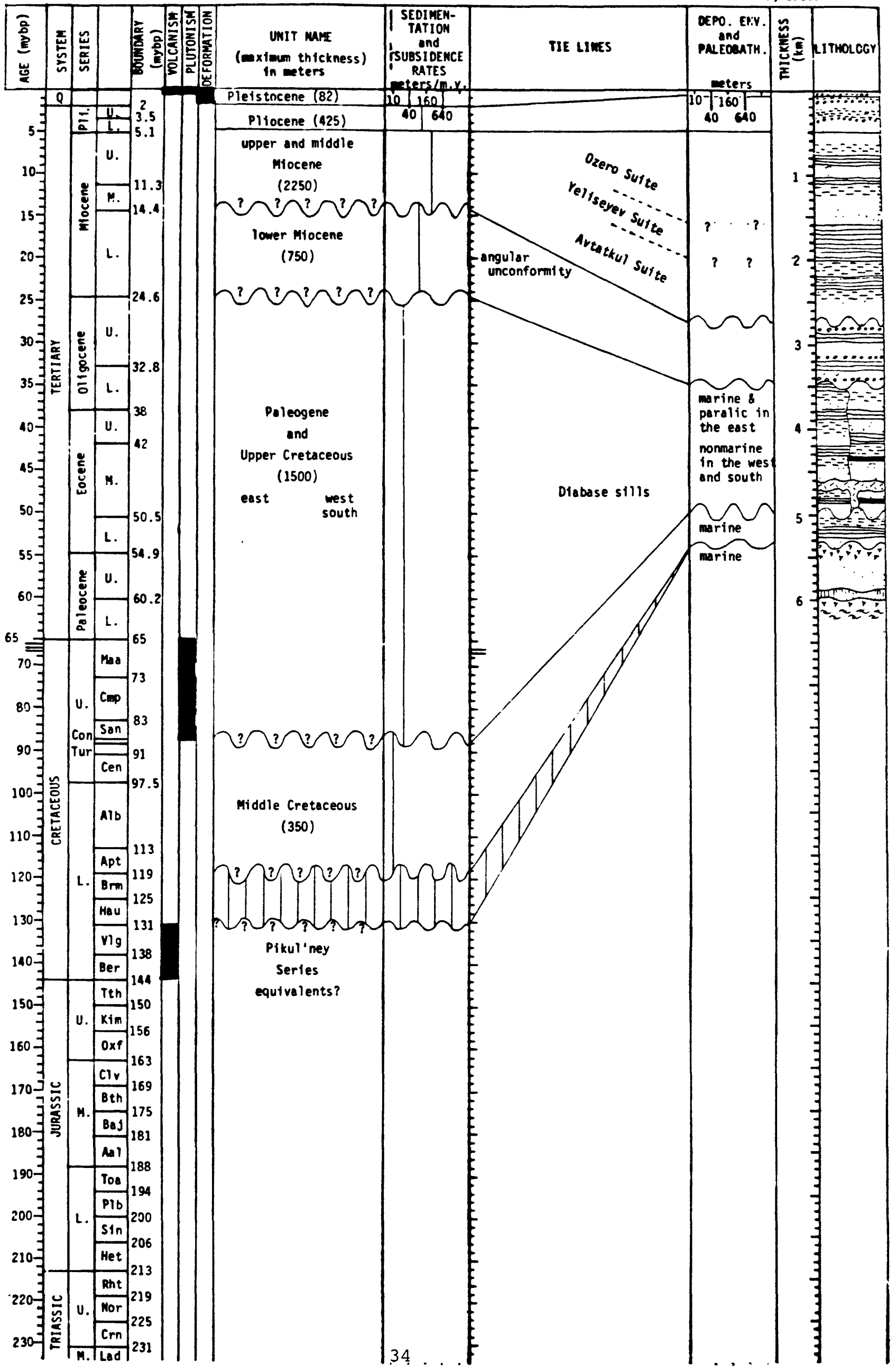




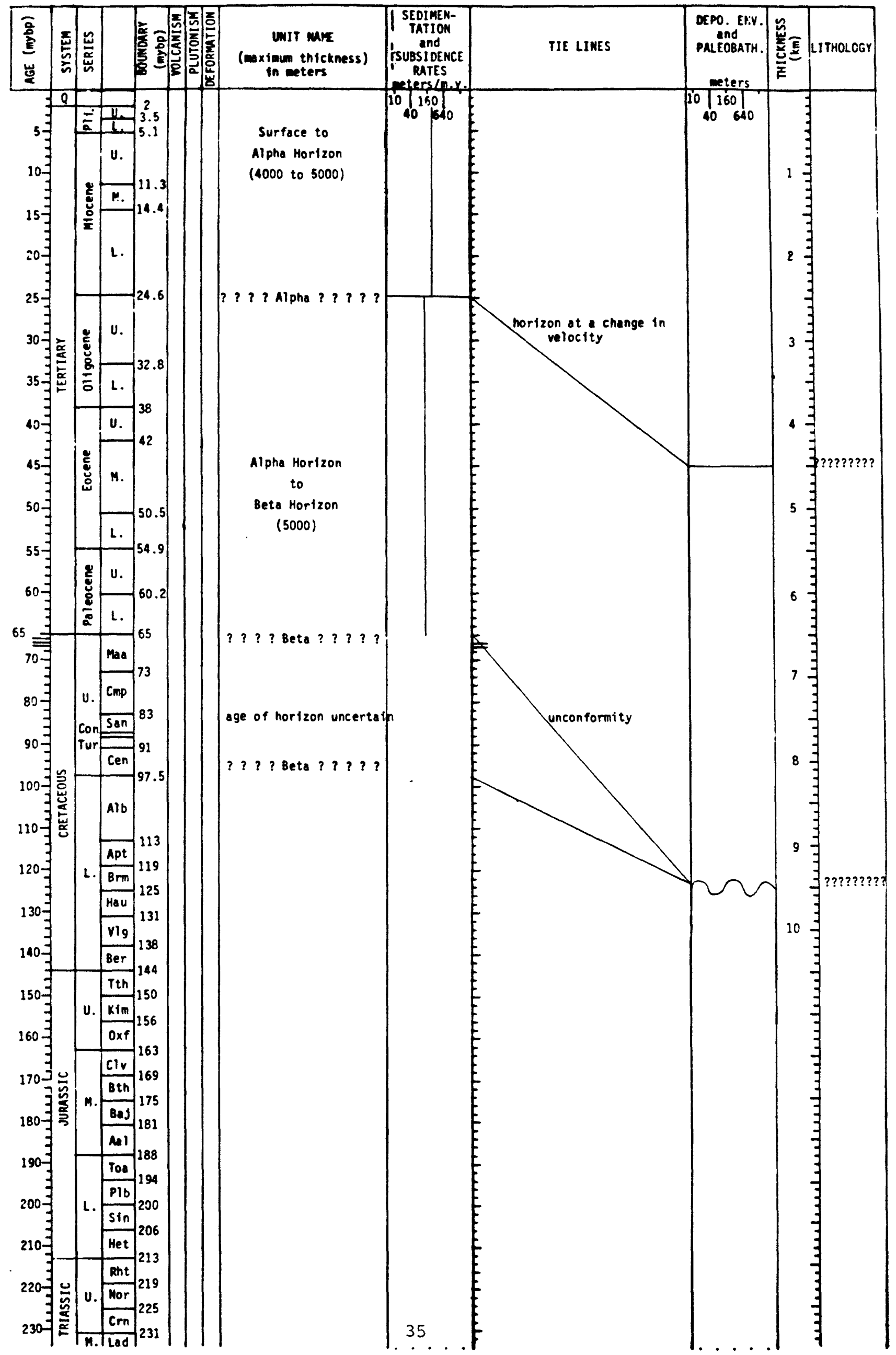




\section{MAVARIN BASIN}

General mformation-- Navarin basin is located on the Bering shelf at lat. $60^{\circ} \mathrm{N} .$, long. $177^{\circ} \mathrm{W}$ (Plate 1). It has an area of about 62,000 square $\mathrm{km}$. Throughout the basin water depths are shallower than $800 \mathrm{~m}$, usually between 100 and $200 \mathrm{~m}$. Cretaceous (?) and younger sediments that fill the basin are in places more than $10 \mathrm{~km}$ thick. Navarin basin forms the Navarin Basin planning area.

Geologic and Cagraphic Boundaries-- Anadyr ridge--probably an offshore extension of the Koryak uplift and Koryak melange belt of eastern Siberia-forms the northern boundary of the basin and separates it from Anadyr basin. The U.S.-U.S.S.R. convention line forms a political boundary on the northern and northwestern sides of the basin near lat. $63^{\circ} \mathrm{N}$. Navarin Ridge and an acoustic-basement high form the western and southwestern boundaries of the basin. The southern margin of the basin is near lat. $58^{\circ} \mathrm{N}$. The okhotskChukotsk volcanic belt bounds the basin near long. $174^{\circ} \mathrm{W}$.

Basin Shape-- Navarin basin is elongate along a north-south trend, $400 \mathrm{~km}$ long by $190 \mathrm{~km}$ wide. The thickest sedimentary sections $(>10 \mathrm{~km})$ lie in three filled subbasins. The northern subbasin, Navarinsky, has an area of about 7000 square $\mathrm{km}$. The central subbasin, Pervenets, has an area of about 4000 square $\mathrm{km}$. The southern subbasin, Pinnacle Islands subbasin, has an area of 8000 square $\mathrm{km}$.

Structural Geology-- Strata in the Navarinsky subbasin are arched into anticlines 10 to $15 \mathrm{~km}$ across. On seismic records the anticlines appear to have diapiric cores. Folding occurred during late Miocene thru Pliocene, in response to deformation and uplift of the Koryak range (and presumably of Anadyr Ridge). Pervenets subbasin shows several kilometers of thickening in the mid-lower part of the upper reflective sequence. In the northeastern part of the basin, in an area underlain by a gravity high, the upper part of the section (late Miocene thru Pliocene?) shows southwesterly dips. Elongate grabens in the southern part of the basin create a series of northwesttrending basins and ridges that parallel the basin margin (Marlow and others, 1981). Growth faults parallel the basin margin in the two southern subbasins.

Basement-- Basement beneath the northeast side of the basin is volcanic and plutonic rocks of the Okhotsk-Chukotsk magmatic arc. Acoustic basement is formed by a folded Late Cretaceous sequence cut by a wave-base unconformity of early Tertiary age (and may locally include an early Tertiary volcanic sequence like that drilled in st. George basin. Crustal basement is inferred to be intermediate or oceanic crust.

Basin Type-- Navarin basin is probably a transform basin (inferred from en echelon nature of the subbasins and intervening ridges, and from plate motions).

stratigraphy-- Source areas for Navarin basin sediments lie in Alaska and Siberia. The ancestral Yukon, Kuskokwim, and Anadyr Rivers probably provided most of the terrigenous basin fill.

Cretaceous and early Tertiary calc-alkaline volcanic and intrusive rocks occur in the Okhotsk-Chukotsk volcanic belt and were drilled in St. George basin to the south. Tuffaceous sediments of Late Cretaceous age (Campanian) were encountered in the Navarin COST No. 1 well. Dredge hauls on the Navarin continental slope recovered tuffaceous sandstones of late oligocene age (Turner and others, 1984c). The COST well also drilled through Miocene diabase sills intruded into the late cretaceous sequence (Turner and others, 1984c). Young basaltic volcanic rocks crop out on the Pribilof Islands and on the Bering Shelf (Marlow and others, 1983b).

Prominent seimic Borizons-- The following is summarized from Turner and 
others (1984C). Four seismic horizons (A through D) divide the section into five sequences ( $I$ through $V$ ). Sequence $I$ (Figure 23) lies between the seafloor and horizon $A$, it forms a basin-wide zone of continuous, parallel, flat-lying reflectors (equivalent to the late miocene and younger section above $957 \mathrm{~m}$ in the cosT well). Horizon $A$ is locally an unconformity, but at the cosT well it represents a boundary between two lithologic zones and may be a depositional hiatus. Horizon $A$ may also represent a bottom-simulating reflector (BSR) related to diagenetic alteration of opal A to clinoptilolite and clay (at the COST well) or opal A to opal CT. Sequence II (late oligocene through late Miocene, 2127-957 $\mathrm{m}$ in the COST well) consists of laterally continuous bedding and apparently represents continuous deposition; these strata are the first to extend beyond the structurally controlled limits of all the subbasins. Horizon $B$, at the base of sequence II, is locally an unconformity, in the subbasins it is at most a depositional hiatus. Sequence III (between 3225 and $2127 \mathrm{~m}$ in the COST well; late oligocene) consists of discontinuous, parallel, variable-amplitude reflectors at shallow levels and more continuous, higher amplitude reflectors in deeper parts of the basin. Locally, sequence III strata are interpreted as proximal turbidite deposits that onlap local structural highs. Horizon $C$ is an indistinct (discontinuous and variable amplitude at shallow levels) to distinct (continuous and high amplitude in deeper parts of the subbasins) reflector that is locally an unconformity. Sequence IV (3743 to $3225 \mathrm{~m}$ in the cosT well; late middle (?) Eocene to early oligocene) consists of laterally discontinuous reflectors deposited in an apparently continuous vertical sequence. At the shelf break sequence IV is locally interpreted as proximal turbidite deposits flanking basement highs. Dredge samples suggest sequence IV may contain early Eocene and Paleocene rocks not present in the COST well. Seismic horizon $D$ is a distinct angular unconformity that separates acoustic basement from Navarin basin fill. Sequence $V$ (acoustic basement) shows variable amplitudes, discordant reflections, diffractions, and incoherent noise; it occurs below $3743 \mathrm{~m}$ in the COST well where it includes Maastrichtian and Campanian or older strata.

Gravity-- Anomalies are associated with diapiric structures and also occur along the basin margin, bordering the igneous (?) rocks of Nunivak Arch (Marlow and others, 1983b).

ragnetics-- An anomaly along the east side of the basin may represent a change in the basement type (Marlow and others, 1983b).

petroleu Geology-- The following is summarized from Turner and others, 1984c. The diagenetic alteration of opal A to clinoptilolite and clay is observed in cores from the cosT well from 929-1019 m. Dredge samples include opal CT, so diagenesis of opal A to opal CT to quartz may occur in other parts of the basin. These diagenetic fronts are likely the cause of bottomsimulating reflectors (BSRs) seen on seismic profiles. Authigenic minerals present in the COST well include pyrite $(311-4841 \mathrm{~m})$, clinoptilolite or heulandite (311-4841 m), chlorite (311-4841 m), siderite (1019-4841 m), smectite $(1019-2723 \mathrm{~m})$, analcite $(1019-1369 \mathrm{~m})$, calcite $(1019-4841 \mathrm{~m})$, gypsum $(2015-3134 \mathrm{~m})$, quartz $(2015-4841 \mathrm{~m})$, feldspar $(2015-4841 \mathrm{~m})$, mixed layer clays $(2015-4841 \mathrm{~m})$, chert $(3134-4506 \mathrm{~m})$, and kaolinite $(3134-4841 \mathrm{~m})$.

One interpretation of interval velocities between 900 and $1020 \mathrm{~m}$ suggests the porosity drops from about 588 to about 388 through the diagenetic zone beneath the BSR (estimates from well logs, these porosity values are probably 5 to $158 \mathrm{high}$ ). The best potential reservoirs encountered in the cosT well occur in Miocene to Oligocene rocks between 1019 and $2016 \mathrm{~m}$. Permeabilities greater than 100 md and porosities greater than 348 were not measured below 


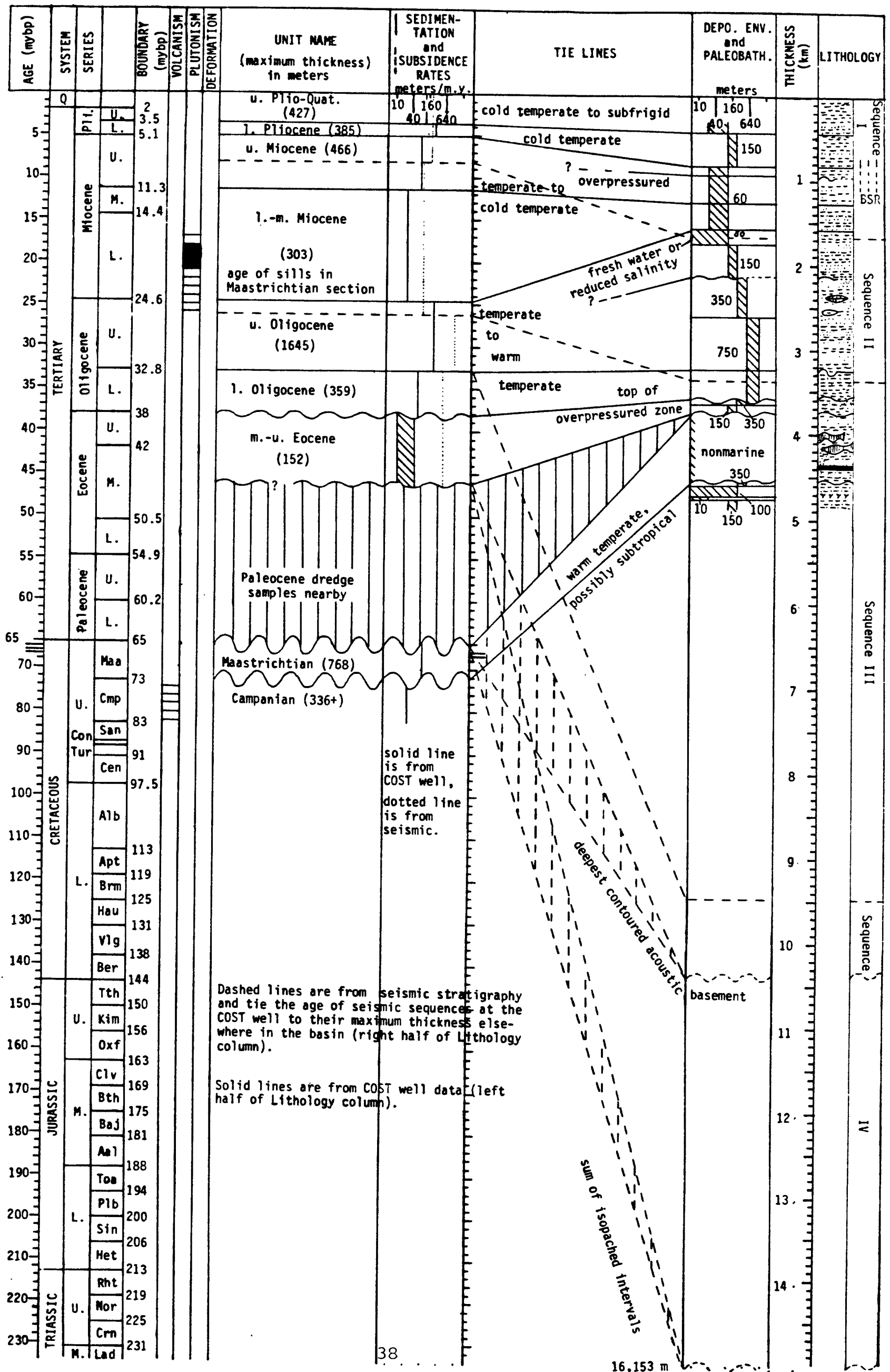


$1785 \mathrm{~m}$.

Overpressured zones occur from 604 to $1019 \mathrm{~m}$ and from 2723 to $4841 \mathrm{~m}$ in the cost well.

Oil shows and relatively high background gas were recorded between 3585 and $3738 \mathrm{~m}$ (middle-late Eocene). Fossils, dark color, and high organic carbon values suggest sediments in this zone were deposited in an anaerobic outer shelf to upper slope environment. Bright spots and wipeout zones on seismic profiles collected over the central arch may be caused by shallow gas.

Vitrinite reflectance (RO) exceeds 0.68 below $2890 \mathrm{~m}$ and 1.358 below $4414 \mathrm{~m}$. Anomalously high Ro values (4.08) are associated with sills that intrude the section below $3737 \mathrm{~m}$. Nearby dredge samples show vitrinite reflectance values of 0.31 to 1.148 . Spore coloration index reached 3.5 (threshold for peak oil generation) at about $1824 \mathrm{~m}$ and 7.0 in the unmetamorphosed part of the section below $4110 \mathrm{~m}$. Pyrolysis suggest the oil generation window $\left(435^{\circ} \mathrm{C} \leq \mathrm{T} 2 \max \leq 470^{\circ} \mathrm{C}\right)$ is between 3664 and $4396 \mathrm{~m}$.

Total organic carbon (TOC) values range up to 508 (coal), and are as high as 28 in the interval between 3585 and $3738 \mathrm{~m}$. A plot of hydrogen index vs. oxygen index (Van Rrevelen diagram) suggests type I, II, and III are all present in the well. Four samples from the cored interval between 3715 and $3726 \mathrm{~m}$ have hydrogen indices ( $\mathrm{mg}$ hydrocarbons per gram TOC) of 290 to 370 and oxygen indices (mg carbon dioxide per gram TOC) of 0 to 7.5.

In the COST well the geothermal gradient is reported as $45.58^{\circ} \mathrm{C} / \mathrm{km}$ in the upper $1000 \mathrm{~m}$ and $32.44^{\circ} \mathrm{C} / \mathrm{km}$ from 1000 to $4841 \mathrm{~m}$, an average of $35.47^{\circ} \mathrm{C} / \mathrm{km}$. The basinwide geothermal gradient is estimated at $40^{\circ} \mathrm{c} / \mathrm{km}$ based on the depth to the BSR (assuming the BSR represents an opal A to opal CT diagenetic front).

Mps and Other Illuatrations-- Location and isopach maps appear with seismic profiles and cross sections in Marlow and others, 1983b; and Turner and others, 1984c, 1985. A structure-contour map has been prepared by Cooper and others, 1979.

Degree of coverage-- Coverage includes 14 dredge stations in or near the basin, 14 seismic refraction lines, a multi-channel seismic net with $5 \mathrm{~km}$ line spacing, and $1000 \mathrm{~km}$ of single channel seismic data.

References-- For more information see Marlow and others, 1983a and b, 1981, 1979, and 1976; Cooper and others, 1979; and Turner and others, 1984c, 1985.

\section{SAMT GBORGB BASIN}

Caneral Information-- Saint George basin is located on the southern Bering Shelf between lat. $55^{\circ} 40^{\prime} \mathrm{N}$., long. $165^{\circ} 30^{\prime} \mathrm{W}$. and lat. $56^{\circ} 40^{\prime} \mathrm{N} .$, long. $169^{\circ} \mathrm{W}$. The basin covers an area larger than 12,000 square $\mathrm{km}$. Water depths range from 100 to $200 \mathrm{~m}$. More than $10 \mathrm{~km}$ of Cenozoic strata fill the basin (Figure 24). It is part of the saint George planning area.

Ceologic and Geographic Boundaries-- Basement shallows on the northern side of the basin. Southwest-dipping normal faults form the northeastern boundary of the basin. Pribilof Ridge, a structural high in the basement complex, lies northwest of the basin. Black Hills Ridge (an anticlinal structure), Unimak basin, and Amak basin lie south of the basin. To the southwest, Pribilof ridge and a system of northeast-dipping normal faults bound the basin. Bristol Bay basin lies east of Saint George basin.

Basin Shape-- Saint George basin is elongate, $300 \mathrm{~km}$ long by 30 to $50 \mathrm{~km}$ wide, and parallels the northwest-southeast trend of the margin. Although seismic profiles across the basin are roughly symmetrical, those along the basin show two subbasins--northwest and southeast--separated by an intervening 


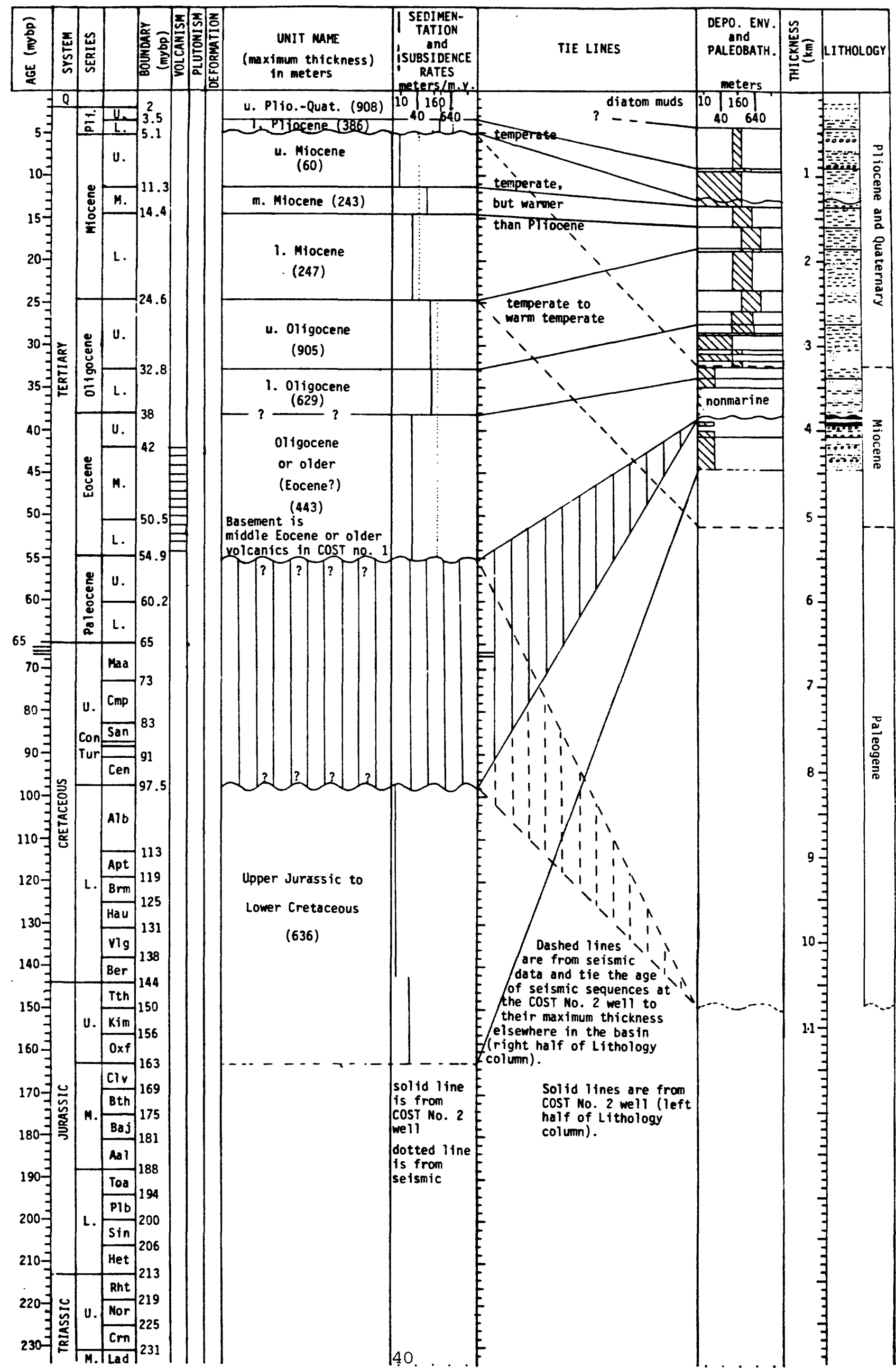


horst.

Structural Gology-- Normal faults and growth faults that parallel the basin axis have been active since the Late Cretaceous or early Tertiary (70 to $50 \mathrm{Ma})$. These faults cut the section from near basement to the surface. Broad anticlines and some tighter folds are associated with normal faults and growth faults. Locally, strata drape over fault blocks in acoustic basement.

Basement-- Acoustic basement consists of folded Mesozoic sedimentary rocks (COST No. 2 well) and middle Eocene or older volcanic rocks (COST No. 1 well). Upper cretaceous rocks have been dredged near the basin. Basement may also include Upper Jurassic equivalents of the Naknek Formation exposed to the east (Figures 24, 25, and 26).

Basin Type-- Saint George basin has been described as a graben, an extensional rift basin, and a rifted Mesozoic forearc basin (Marlow and others, 1977).

stratigraphy-- Sedimentary units in the basin fill thicken across growth faults toward the basin center.

Tertiary volcanism and plutonism occurred nearby on the Alaska Peninsula and Aleutian arc.

Prominent Seisaic Borizons-- Acoustic basement appears to underlie an angular unconformity. Reflectors at the top of oligocene strata and at the top of Miocene strata have been correlated across St. George basin by Turner and others $(1984 a, b)$.

Gravity-- See Watts, 1975. The basin is outlined by a gravity low.

Magnetics-- Total field magnetic anomalies are described in Bailey and others (1976). A residual magnetic map has been prepared by childs and others (1981).

Petroleu Ceology-- Organic carbon content of dredge samples exceeds 0.258 in Tertiary mudstone, 18 in Cretaceous mudstone, and 0.278 in one Late Jurassic sample. Eocene thru Pliocene age dredge samples have an average porosity of 488. Neogene sandstone on the Alaska Peninsula has good reservoir characteristics to $2400 \mathrm{~m}$ (McLean, 1977).

Authigenic pyrite is present throughout the wells. Other authigenic minerals common in the cosT wells include smectite $(1571-2336 \mathrm{~m})$, chlorite $(2139-3840 \mathrm{~m})$, calcite $(2578-4457 \mathrm{~m})$, siderite $(2327-4457 \mathrm{~m})$, laumontite $(3065-4457 \mathrm{~m})$, and quartz $(2825-3840 \mathrm{~m})$.

Porosity decreases downhole in COST No. 2 well from 408 to 38 at total depth $(4458 \mathrm{~m})$, and exceeds 108 to a least $3871 \mathrm{~m}$. Permeability ranges from $111 \mathrm{md}$ to less than $0.01 \mathrm{md}$ in conventional cores from the well. Average permeabilities $\geq 10 \mathrm{md}$ are restricted to sandstone units with porosities $>208$ (shallower than $2438 \mathrm{~m}$ ).

Total organic carbon in the two cosT wells typically ranges from 0 to 18 and in a few instances exceed 18. Kerogen averaged 508 vitrinite; four samples from the COST No. 2 well exceed 358 amorphous kerogen. One coalysiltstone sample from $3827 \mathrm{~m}$ in the COST No. 2 well has TOC of $2.38,708$ amorphous kerogen, and hydrogen/carbon ratio of 1.16 (Turner and others, $1984 \mathrm{a}, \mathrm{b})$ Maturity sufficient for peak oil generation probably exists below about $3777 \mathrm{~m}$ (Ro > 0.68 ).

The geothermal gradient reported by Turner and others $(1984 a, b)$ ranges from $26.8^{\circ} \mathrm{C} / \mathrm{km}$ in $\cos T$ No. 2 well to $35.5^{\circ} \mathrm{C} / \mathrm{km}$ in $\operatorname{cosT}$ No. 1 well. Recalculating these gradients using maximum bottom-hole temperatures and assuming seabed temperatures of $4^{\circ} \mathrm{C}$ gives $32.9^{\circ} \mathrm{C} / \mathrm{km}$ for $\operatorname{cosT}$ No. 2 well and $37.9^{\circ} \mathrm{C} / \mathrm{km}$ for CosT No. 1 well.

Mpe and other Illustrations-- Seismic profiles and line drawings appear in Marlow and others, 1979b. A map showing location and thickness appears in 


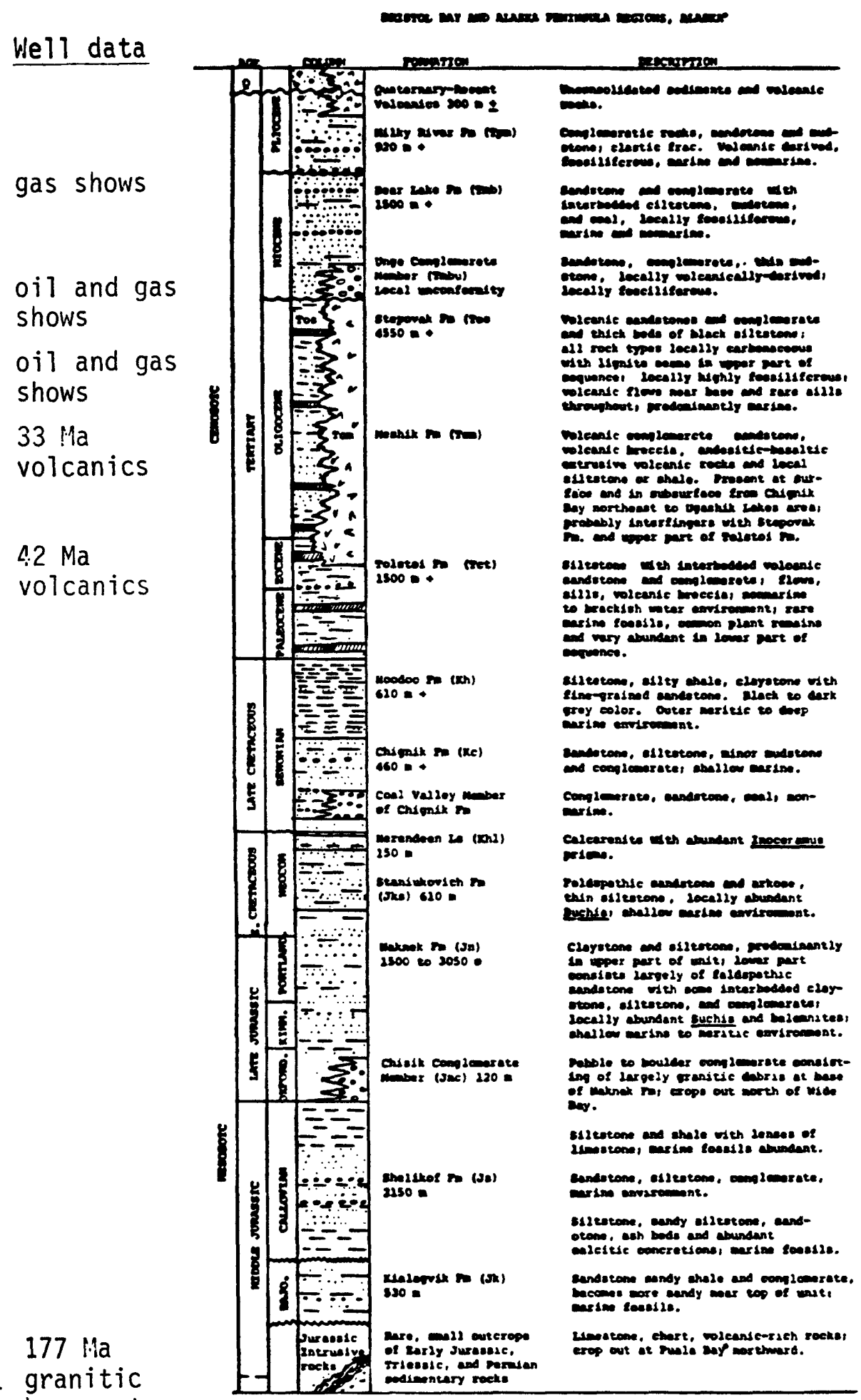

Peninsula regions.

Figure 25. From Brockway and others, 1975, as modified by Marlow and others, 1979b. Well data (left column) from Marlow and others; 1979b. 
COMPOSITE COLUMNAR SECTION

NUSHAGAK LOWLANDS, ALASKA

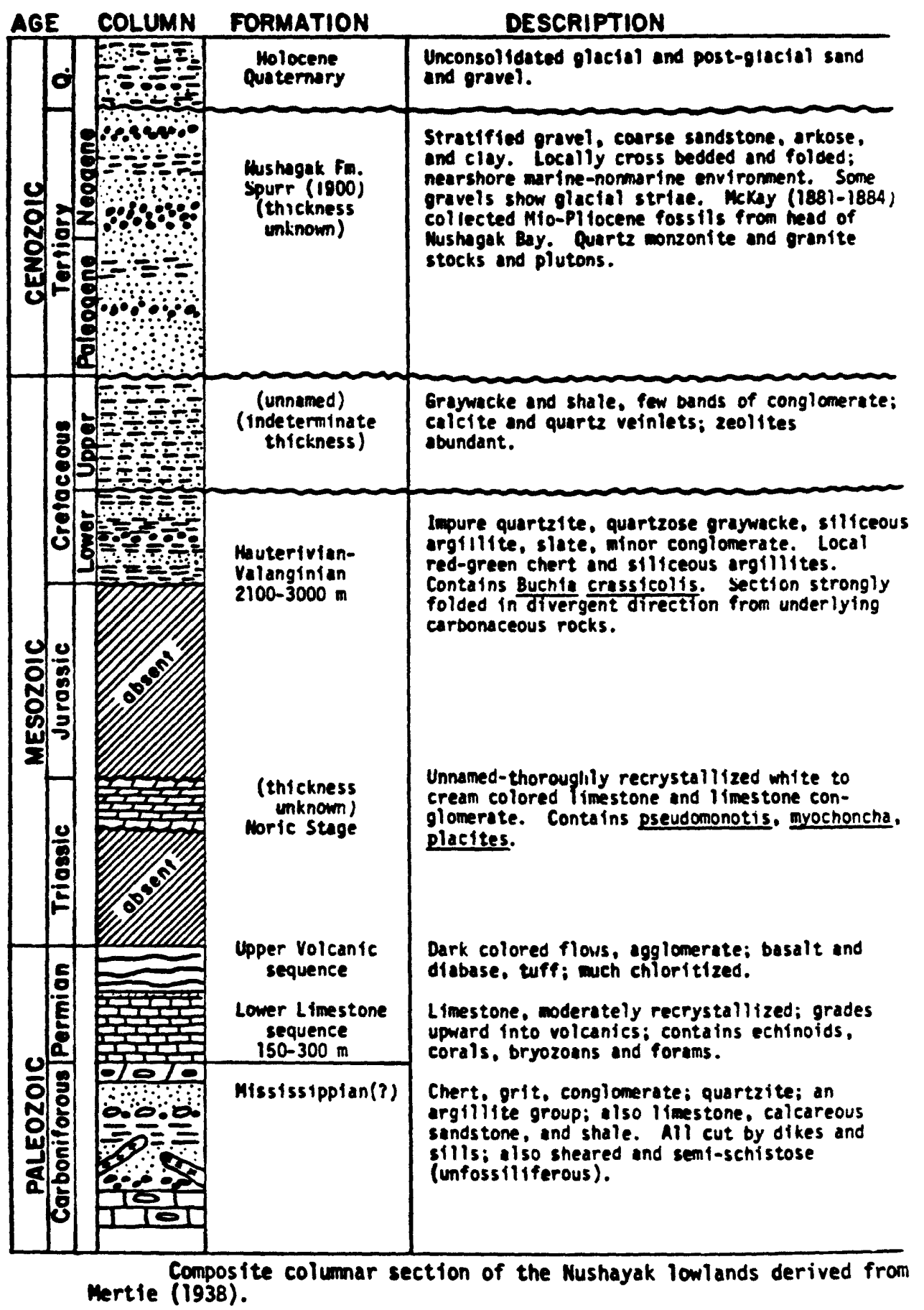

Figure 26. From Marlow and others, 1979b. 
Cooper and others, 1979. An isopach map has been prepared by Marlow and others, 1979a.

Degree of coverage-- Six hundred kilometers of multi-channel seismic data, dredge hauls, three seismic refraction lines (Marlow and others, 1979b), and two COST wells (Turner and others, 1984a,b) cover the basin.

other Information-- Basin extension may have resulted from rebound following the cessation of subduction at the shelf edge and formation of the subduction zone along what is now the Aleutian Arc.

References-- For more information see Marlow and others, 1977, 1979a and b; Cooper and others, 1979; Bailey and others, 1976; Watts and others, 1975; Childs and others, 1981; Pratt and others, 1972; Watts, 1975; and Turner and others, $1984 a, b$.

\section{AMAR BASIN}

Ceneral Information-- Amak basin is located on the Bering Shelf at lat. $55^{\circ} \mathrm{N}$. , long. $165^{\circ} \mathrm{W}$. It has an area of 2400 square $\mathrm{km}$ and lies in water 50 to $200 \mathrm{~m}$ deep. Four kilometers of Cenozoic sedimentary strata fill the basin. Amak basin is part of the North Aleutian planning area.

Geologic and Coographic Boundaries-- The basin fill onlaps Black Hills Ridge--an antiform cored by Jurassic sedimentary rocks--on the northern and northeastern sides of the basin. The sedimentary section thickens towards the slope on the western and southwestern sides of the basin. Unimak Island and outcrops of igneous rocks lie south of the basin. Late cenozoic igneous rocks also crop out east of the basin on the Alaska Peninsula.

Basin Shape- The western part of Amak basin is narrow and elongate along an east-west trend, the eastern end of the basin is wider, nearly circular in plan view. The basin fill is thicker to the east. In cross section, the acoustic basement surface on the northeast side of the basin, adjacent to Black Hills Ridge, is steeper than on the basin's southwest side.

structural Geology-- Flat or gentle southern dips predominate except where folding and high-angle faulting occur along the southwestern flank of the Black Hills Ridge. There is also minor faulting and folding in the northBagtenent-- Acoustic basement consists of a sequence of poor reflectors that lie below a major (early Tertiary?) unconformity. The basement sequence is probably Mesozoic in age, and may be equivalent to the Jurassic Naknek Formation. Crustal basement is probably continental rocks of the Peninsular Terrane. basin.

Basin Type- Amak basin is a gentle crustal sag or depression, a shelf

Stratlgraphy-- Sedimentary units onlap Black Hills Ridge. They thicken basinward and thin southwest of the basin center.

Throughout most of the Tertiary, volcanism and plutonism occurred nearby on the Aleutian arc and Alaska Peninsula.

Prominent Seiemic Borisons-- Up to $4 \mathrm{~km}$ of laterally continuous reflectors, interpreted to represent cenozoic strata, are underlain by a major angular unconformity, possibly of early Tertiary age (Figure 27). This $4 \mathrm{~km}$ thick Cenozoic section is underlain by up to $3 \mathrm{~km}$ of discontinuous reflectors that form the Mesozoic (?) acoustic basement.

Gravity-- See Watts, 1975.

ragnetice-- A regional magnetic map that includes Amak basin has been prepared by Childs and others, 1981.

ups and other Illustrations-- see Marlow and others (1979a) for an isopach map of Amak basin. Structure-contour maps of Amak basin include those 


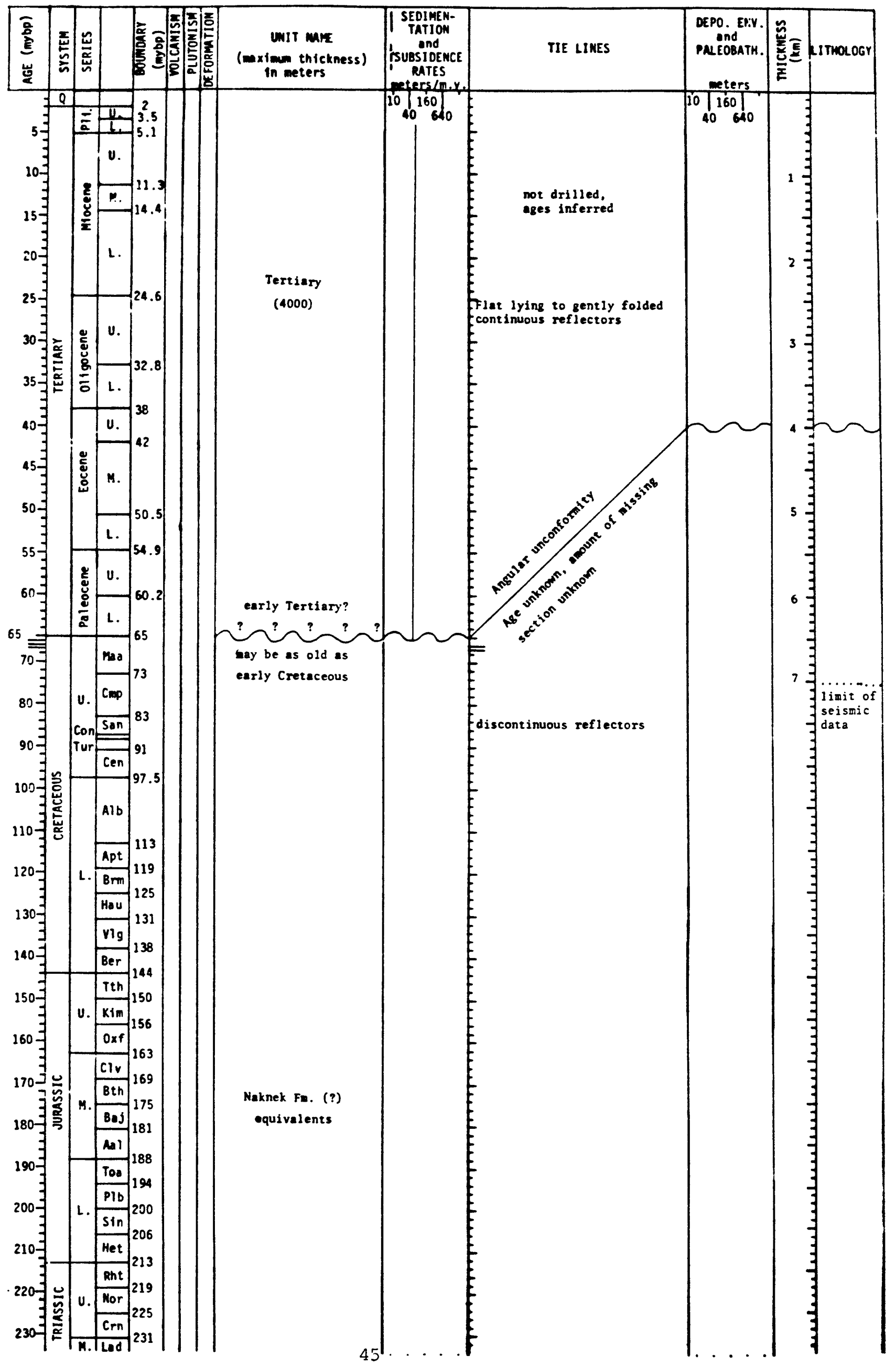


by Cooper and others (1979) and Marlow and others (1979b). Seismic profiles crossing the basin appear in Marlow and Cooper (1980).

Degree of coverage- More than $110 \mathrm{~km}$ of 24 channel seismic reflection data at $100 \mathrm{~km}$ spacing is available for Amak basin.

other Information- For basin history diagrams derived from nearby onshore sections see Shumagin basin (Figure 39) and St. George basin (Figures 25 and 26 ).

References-- For more detailed information see Marlow and others, 1980, $1979 \mathrm{a}$ and $b_{i}$ Cooper and others, 1979; Marlow and Cooper, 1980; Watts, 1975; Childs and others, 1981; and McLean, 1979b.

\section{BRISTOL BAY BASIN}

Ceneral Information-- Bristol Bay basin is located at lat. $56^{\circ} \mathrm{N}$. , long. $162^{\circ} \mathrm{W}$ (Figure 28). Offshore, the basin covers 18,900 square $\mathrm{km}$ (sedimentary section more than $1.5 \mathrm{~km}$ thick). Estimates of the total area of the basin, including onshore areas and those with sections less than $1.5 \mathrm{~km}$ thick, are as high as 256,000 square $\mathrm{km}$. More than $7 \mathrm{~km}$ of Jurassic and younger strata are present. Water depths are less than $100 \mathrm{~m}$. Bristol Bay basin is part of the North Aleutian planning area.

Geologic and Geographic Boundaries-- Mesozoic sedimentary, volcanic, metamorphic, and crystalline rocks crop out north of Bristol Bay basin. Nunivak Arch lies northwest of the basin. Black Hills Ridge, an antiformal structure containing Jurassic sedimentary rocks, lies south and southwest of the basin. Folded Jurassic rocks crop out on the Alaska Peninsula southeast of the basin. Bristol Bay basin is bounded by deformed, intruded, and metamorphosed Paleozoic and Mesozoic rocks along its northeastern margin.

Basin shape-- Bristol Bay basin is elongate with an east-northeast trend (Figure 28). The basin fill is thickest near Port Moller on the Alaska Peninsula. It is asymmetric in cross section, with a steeply inclined basement surface on the southeastern flank and a gently inclined basement surface on the northwestern flank.

structural Geology-- Anticlines seem to have formed by differential compaction of Cenozoic sediments deposited over erosional and faulted basement highs. The upper part of the basin fill is flat lying, the lower part is mildly folded or draped over basement blocks.

Eacement-- Economic basement is formed by igneous rocks of the Alaskan Peninsula and by Mesozoic and Paleozoic sedimentary rocks. Acoustic basement is made up of deformed Late Cretaceous sedimentary rocks. Crustal basement is inferred to be rocks of a Mesozoic magmatic arc. Gravity and magnetics seem to define two different basement types. Ultramafic rocks are exposed on the nearby Pribilof Islands. Basement subsidence began in the late Mesozoic and continued through the cenozoic.

Basin Type-- Bristol Bay basin is a structural sag.

Stratigraphy-- The source area for basin filling sediments was probably cratonic Alaska.

Coarse-grained units include the Bear Lake Formation and Milky River Formation. The Bear Lake Formation has more than $1500 \mathrm{~m}$ of mid-late Miocene sandstone and conglomerate with lesser thicknesses of siltstone, mudstone, and coal; sandstone porosity ranges up to 36.58 and permeability to 1,286 millidarcies. The Milky River Formation consists of more than $1000 \mathrm{~m}$ of late Miocene thru pliocene shallow marine sandstone, conglomerate, and mudstone (Figures 29 and 30 ). Sedimentary units thin to the north.

Prominent seimic Eorisons-- The basin fill is divided into a highly reflective unit, composed of many coherent reflectors, underlain by a poorly 


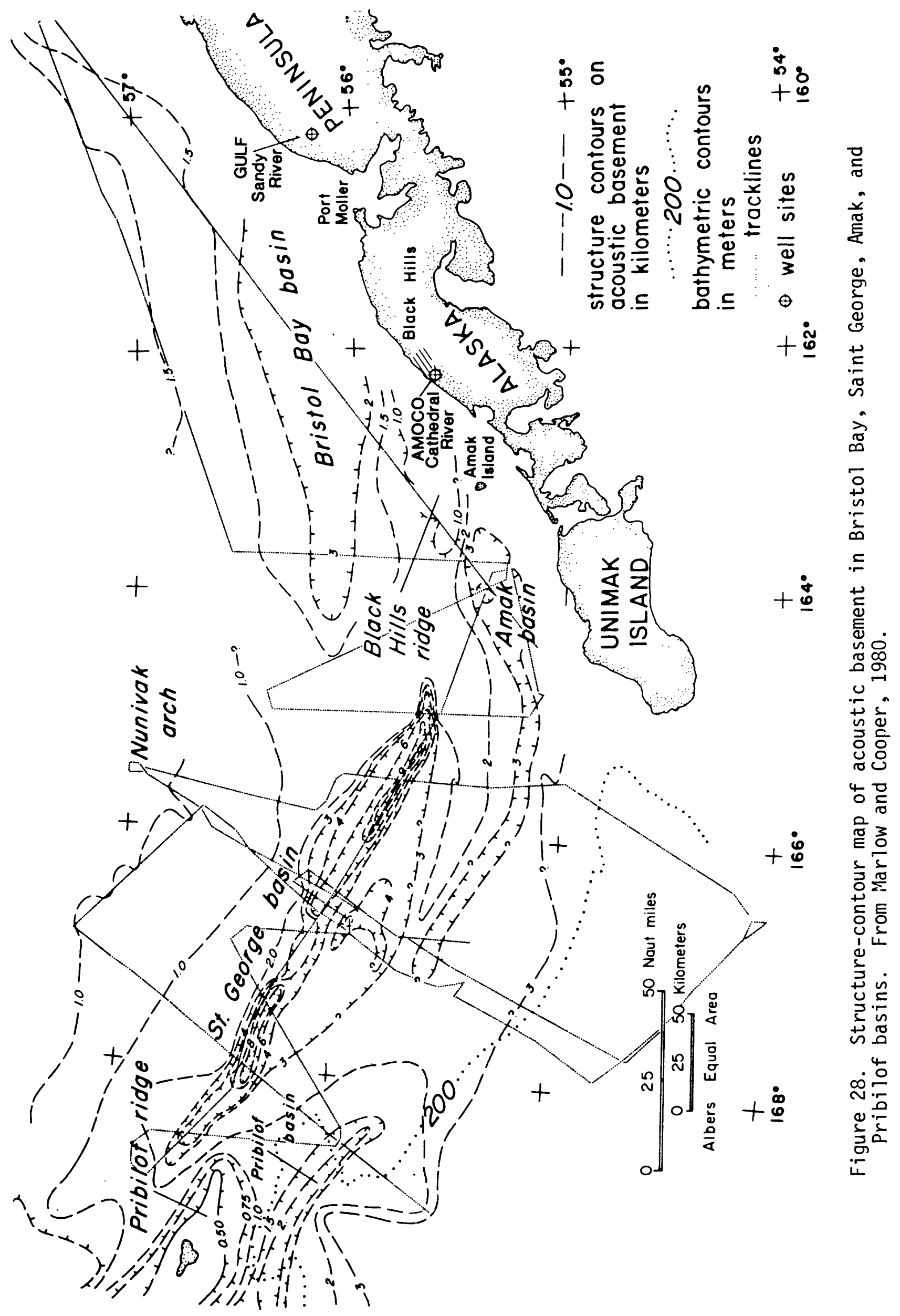




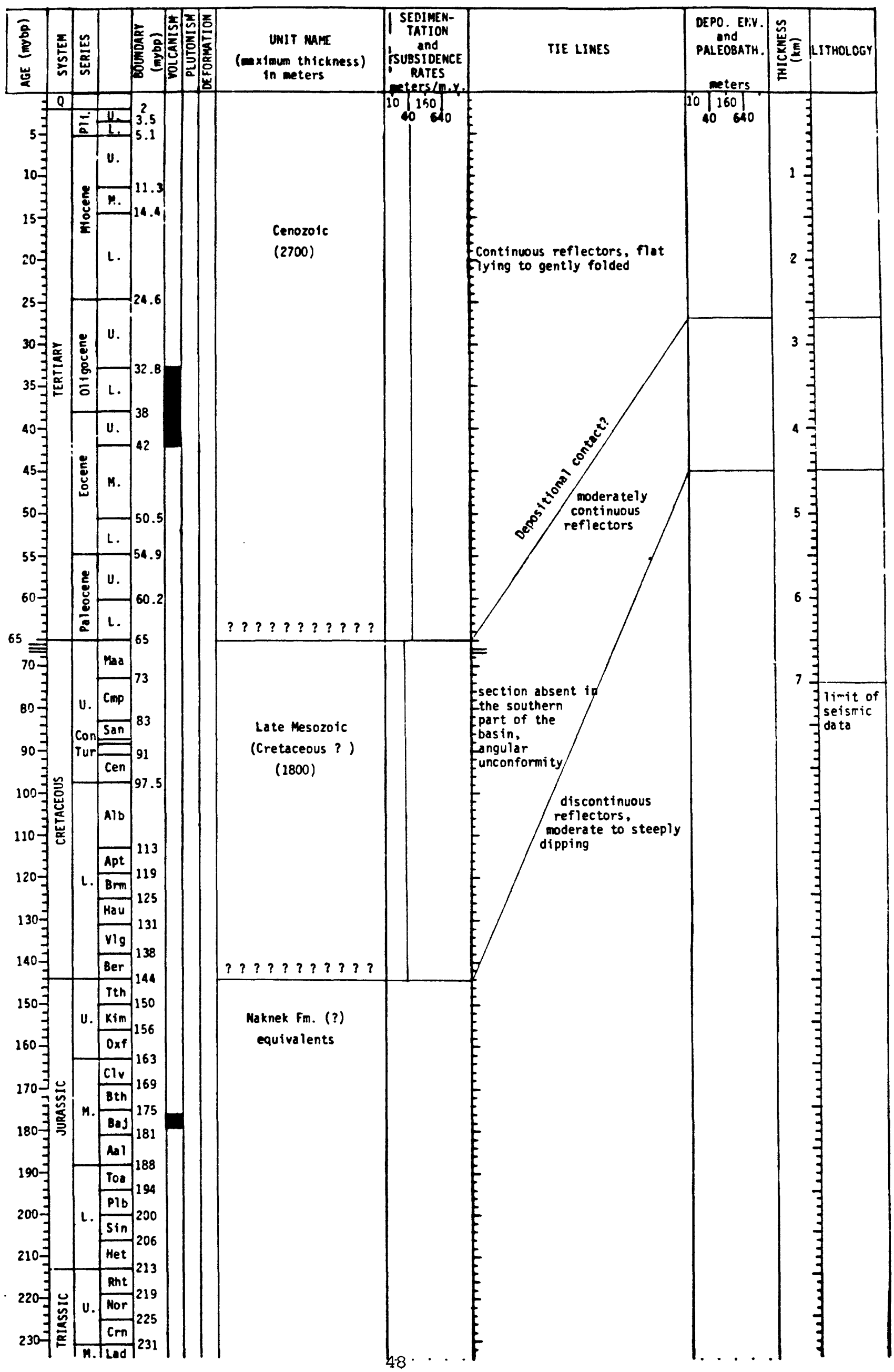


Data from McLean, 1979b; Detterman, 1985.

(Alaska Peninsula)

pers. corm. ; and Marlow and others, 1980

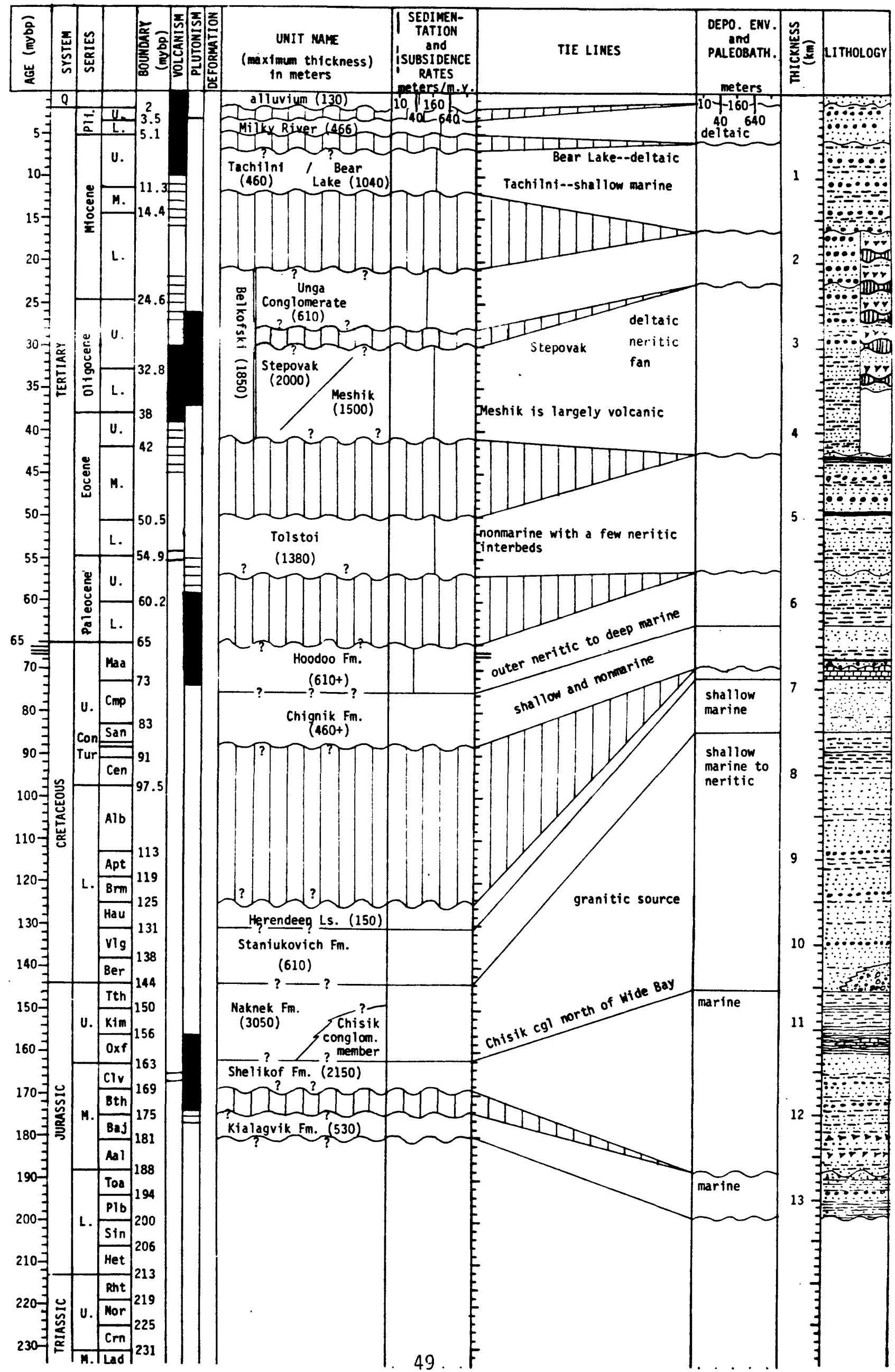


reflective unit (Figure 29).

Gravity-- See Watts, 1975.

Manetics-- See Pratt and others, 1972.

Petroleum Geology-- Paleogene and younger strata are largely immature. However, the oligocene Stepovak Formation may have the greatest potential as a source rock. The total organic carbon content of the Mesozoic section penetrated by the Amoco Cathedral River Unit 1 well was consistantly less than 18 (McLean, 1979b).

Unstable volcanic framework grains and formation of authigenic cements limit the reservoir potential of the coarse-grained Tertiary units (McLean, 1979b). The Mesozoic section also shows low porosity (Marlow and others, 1980).

Maps and Other Illustrations-- See Marlow and others (1980) for a location map and stratigraphic columns. A structure-contour map, seismic profiles, and cross sections appear in Marlow and Cooper, 1980. An isopach map has been prepared by Marlow and others, 1979a. Cooper and others (1979) have prepared a structure-contour map.

Degree of coverage-- More than $6000 \mathrm{~km}$ of geophysical data, including 860 $\mathrm{km}$ of 24 channel seismic-reflection data, have been collected from the basin. Nine wells have been drilled on the Alaska Peninsula.

other Information-- For onshore geology see Shumagin onshore (Figure 39), St. George basin (Figures 25 and 26), and McLean, 1979b. The Amoco Cathedral River Unit 1 well penetrated Triassic strata in the Black Hills. The Cretaceous unconformity in the Black Hills becomes a disconformity in Bristol Bay basin. Subsidence and sedimentation rates seem to have been approximately equal.

References-- For more detailed information see Marlow and others, 1980, 1979a; Marlow and Cooper, 1980; Cooper and others, 1979b; Box, 1985; Watts, 1975; Pratt and others, 1972; McLean, 1979b; and Hoare, 1961.

\section{ALEUTIAN BASIN}

General Information-- The Aleutian Basin is located between lat. $51^{\circ} \mathrm{N}$. and 1at. $63^{\circ} \mathrm{N} .$, and between long. $171^{\circ} \mathrm{W}$. and $171^{\circ} \mathrm{E}$. It covers an area of 650,000 square $\mathrm{km}$ in water depths that average $3600 \mathrm{~m}$. Aleutian Basin includes three major subbasins that contain as much as $10 \mathrm{~km}$ of postCretaceous sedimentary fill (Plate 1).

Geologic and Geographic Boundaries-- Aleutian Basin is bordered by the Beringian margin to the north, the continental shelf off the U.S.S.R. in the northwest, Shirshov Ridge in the west, Bowers Ridge in the southwest, the Aleutian Ridge in the south, the Aleutian Ridge and Umnak Plateau in the southeast, and the Bering Shelf in the east and northeast.

Basin Shape-- The basin shape is irregular. Stratigraphic sequences are thickest near source areas. These include three crescent-shaped (filledtrench?) subbasins. The remainder of the basin underlies the Bering abyssal plain in the central part of the Aleutian Basin. Prior to the middle Miocene, depocenters were in troughs north of Bowers Ridge and southwest of the Bering Shelf. Since the middle Miocene, the main depocenter has been in the northwestern part of the Aleutian Basin.

Aleutian Basin may have been open to the south prior to the formation of the Aleutian Ridge (Cooper and others, 1981).

gtructural Colooy-- Younger strata seem to be draped over basement relief. Deformed and thickened sediments lie adjacent to the north side of Bowers Ridge and to the Beringian margin. Diapirs occur in parts of the basin (Cooper and others, 1979b). Strike-slip or oblique faults probably occur 


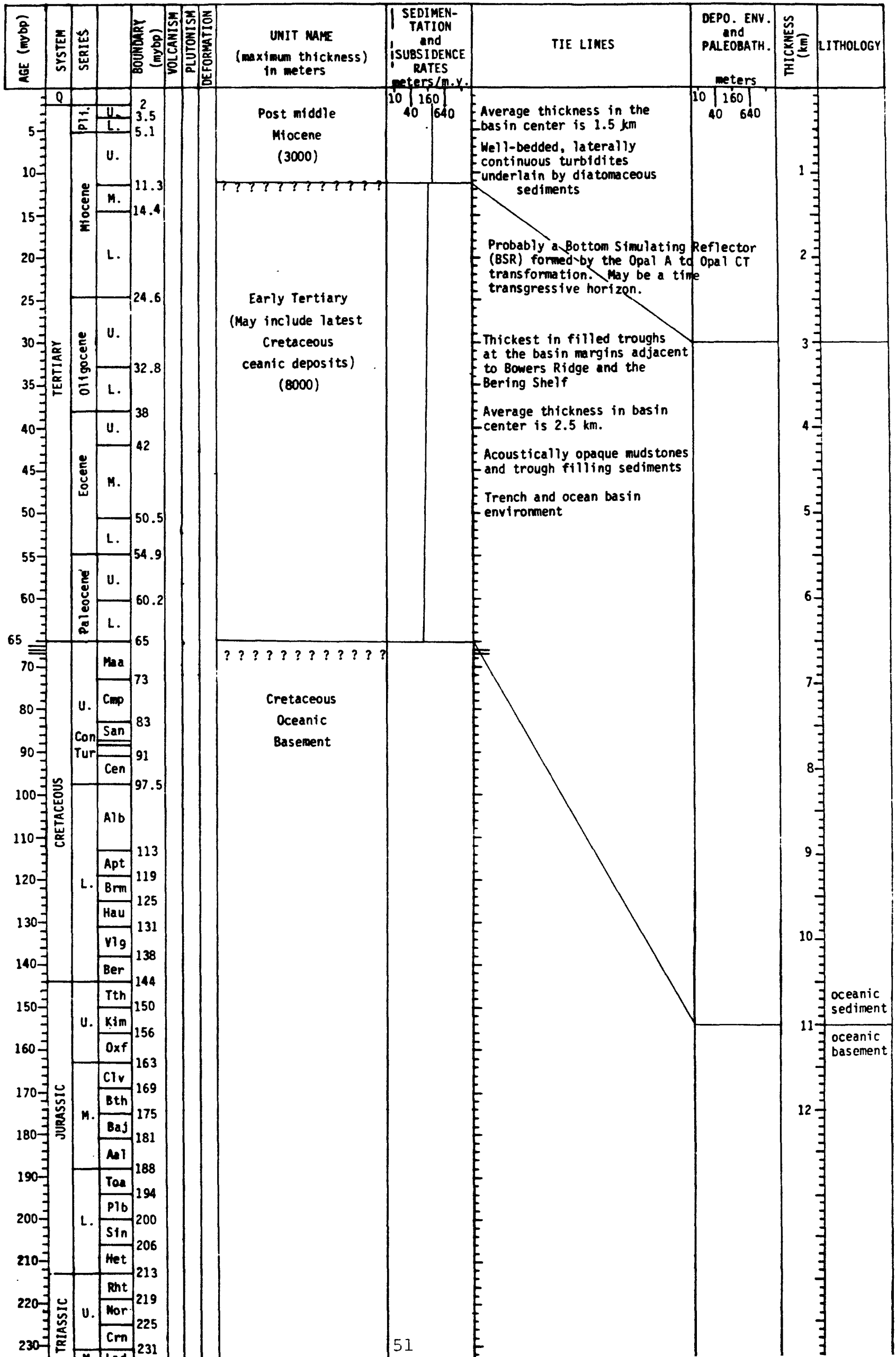


along the Beringian margin.

Basement-- Oceanic crust, probably of Cretaceous age (contains northsouth trending magnetic lineations), at subbottom depths of 4.5 to $5.0 \mathrm{~km}$ is both crustal and acoustic basement throughout most of the basin (Cooper and others, 1976).

Younger ridges have formed locally in the acoustic basement. These ridges have relief up to 1.5 seconds $(3 \mathrm{~km})$ and are up to $15 \mathrm{~km}$ across. Normal faults are apparent in adjacent basin fill. Ridge growth occurred mainly in the early Tertiary, but renewed growth occurred in the late Cenozoic. These ridges may form barriers to sediment dispersal (Cooper and others, 1979b).

Dasin Type-- Aleutian Basin is an ocean basin with filled-trench subbasins on its southwestern, northeastern, and eastern margins, surrounding a deep ocean subbasin.

stratigraphy-- Basin filling sediments presumably fine toward the basin center. A major post-middle Miocene sediment source is located in the Anadyr area. Throughout the early Tertiary, and during later low stands of sea level, the ancestral Yukon River was probably a major sediment source.

coarse-grained units in the basin fill probably include turbidite sands and conglomerates.

Flat, parallel reflectors cover most of the basin. Deformed and thickened wedges of sediment occur in filled trench subbasins.

Volcanism occurred on the basin margins throughout most of the cretaceous and Cenozoic.

Prominent Seianic Borizons-- Two Bottom Simulating Reflectors (BSRs): (1) is probably a time transgressive horizon in post-middle Miocene strata and is interpreted as the opal A to opal CT diagenetic boundary (Figure 31); (2) is probably a shallow gas hydrate BSR.

Acoustic basement forms a second prominent seismic horizon.

Gravity-- Gravity profiles are presented in Ben-Avraham and Cooper, 1981. Gravity maps include those of Watts, 1975; and Childs, Magistrale and Cooper, $1985 a, b, c$.

Nagnetics-- Profiles are presented in Ben-Avraham and Cooper, 1981; Cooper and others, 1981; and cooper and others, 1979b. North-south trending magnetic lineations are described in cooper and others, 1976.

Petroleum Coology-- Cooper and others (1979b) suggest the average geothermal gradient is $58^{\circ} \mathrm{C} / \mathrm{km}$. Ben-Avraham and cooper (1981) report 1 to 1.8 heat flow units. There may be a thermal anomaly beneath the central part of the basin.

Organic carbon measurements on samples from DSDP sites range from 0.2 to 0.88 .

Silica diagenesis, from opal A to opal CT (?), is probably responsible for the BSR. Diatomaceous sediments above the BSR show porosities which increase with depth from 58 to 858 and permeabilities which increase from 10 to 35 millidarcies. Below the BSR porosities decrease to 328 and permeabilities decrease to 0.1 millidarcies (Cooper and other, 1979b).

Turbidites may form seals over diatomaceous units. VAMP's (velocityamplitude structures) may be gas saturated zones that cause images on deepwater seismic profiles equivalent to seismic bright spots.

yaps and Other Illustrations-- See Cooper and others (1979b and 1981) for seismic profiles and cross sections. Cooper and others (1979a) have prepared a structure-contour map which covers Aleutian Basin. Marlow and others (1979a) have prepared an isopach map covering the basin.

Degree of coverage-- The basin is covered by a multi-channel seismic 
grid, many dredge hauls, and two-ship and sonobuoy refraction seismic data. Deep Sea Drilling Project (DSDP) sites 188, 189, and 190 are in or near the basin.

Other Information-- Cretaceous sedimentary rocks may overlie basement.

The most abundant lithologies in the basin fill are diatomaceous sediments and turbidites.

The north and east sides of Bowers Ridge and the Beringian margin are probably ancient convergent or transpressive margins.

Two other large, deep water basins lie north of Aleutian Ridge: Bowers basin is south and west of Bowers Ridge and Komandorsky basin is west of Shirshov Ridge and east of the Kamchatka Peninsula (Plate 1).

References-- For more detailed information see Scholl and others, 1982; Cooper and others, 1976, 1979a and b, and 1981; Childs and others, 1981; BenAvraham and Cooper, 1981; Watts, 1975; and Marlow and others, 1979a.

\section{PRATT DEPRESSIOU}

General mformation-- Pratt depression is located at lat. $52^{\circ} \mathrm{N}$. , long. $179^{\circ} \mathrm{E}$. It has an area of 1000 square $\mathrm{km}$ in water depths to $850 \mathrm{~m}$. Up to 1.8 $\mathrm{km}$ of post-middle Miocene sediment has been deposited in the basin.

Geologic and Ceographic Boundaries-- The northern boundary of Pratt depression is poorly defined, it may be a northward-bowed ridge south of Bowers Ridge. Little Sitkin Island lies west of the depression. The southern boundary of the depression is formed by Prokhoda Scarp--a $385 \mathrm{~m}$ scarp thought to represent an east-west trending down-to-basin normal fault. Oglala sea valley and Amchitka Island lie furthur south of the basin. Semisopochnoi Island is east of the depression. Bowers Ridge and Kay sea cone are northeast of the depression.

Basin Shape-- The depression is rectangular, $50 \mathrm{~km}$ long by $20 \mathrm{~km}$ wide, it is elongate parallel to the Aleutian Ridge crest, and lies near the northern edge of the ridge.

Structural Ceology-- The Kay sea cone is a submerged volcanic center that disrupts the central and northeastern parts of the depression.

Prokhoda Scarp, a major down-to-basin normal fault, and related structures are located along the southern side of the depression.

Basement-- Acoustic basement is formed by middle and/or lower series rocks (Eocene thru middle Miocene?) of the Aleutian Ridge. Crustal basement is the early Tertiary Aleutian Arc massif.

Basin Iype-- The depression is an elongate, intra-arc, summit basin on the Aleutian Ridge.

Stratigraphy-- Volcanism (middle Miocene and Pliocene thru recent over much of the Aleutian Arc) may have affected basin filling sediments. horizon.

Prominent seimic Borisons-- Acoustic basement is the only well defined

Gravity-- Gravity profiles appear in Scholl and others, 1975. Maps include those of Watts, 1975; and Childs, Magistrale, and Cooper, 1985a.

Magnetics-- Profiles appear in Scholl and others, 1975.

raps and other Illustrations-- see scholl and others (1975) for a location map and seismic profile.

Degree of coverage-- One reconnaissance multi-channel seismic reflection line and one sonobuoy seismic refraction line cover the depression.

other mformtion-- The depression is aligned with loci of volcanic centers on the Aleutian Ridge. There are no gaps in the depression walls deep enough to serve as sediment outlets from the basin. The depth of summit basins seems to be inversely proportional to the area of the adjacent summit 
platform.

References-- For more detailed information see scholl and others, 1975; Watts, 1975; and Childs, Magistrale, and Cooper, 1985a.

\section{BULDIR DEPRESSION}

General Information-- Buldir depression is located at lat. $52^{\circ} 15^{\prime} \mathrm{N}$. , long. $176^{\circ} 45^{\prime} \mathrm{E}$. The depression has an area of approximately 1000 square $\mathrm{km}$ in water depths of up to $2000 \mathrm{~m}$. Buldir depression contains up to $0.3 \mathrm{~km}$ of Pliocene thru Quaternary--mainly Pleistocene-sedimentary fill.

Ceologic and Cographic Boundaries-- Buldir Island, a volcanic cone, bounds the basin on the west. The Aleutian arc summit platform lies south of the basin. An unnamed volcano forms the eastern boundary of the depression. on the northeast side of the depression is a gap in the basin walls. The northern boundary of the basin is formed by a ridge whose origin is poorly understood; Bowers basin lies north of the ridge.

Basin Shape-- Buldir depression is a northwest-trending, elongate, rectilinear, perched submarine basin. Its minor axis trends northeast, transverse to the Aleutian Ridge.

structural Cology-- Hydro Cone, probably a volcanic cone, intrudes the basin filling sediments. The floor of the depression is generally flat with minor relief--100 to $500 \mathrm{~m}$-in the northwestern portion. Basin-filling sediments are generally undeformed except where they overlie normal faults in the basement. In some places sediments seem to be draped over the basin walls.

Basement-- High-angle normal faults in the acoustic basement dip towards the basin center. Crustal basement consists of the early Tertiary Aleutian arc massif. Acoustic basement and the basin's walls are probably middle and lower series rocks of middle Eocene thru middle Miocene age.

Basin Type-- Buldir depression is probably a graben formed by extensional rifting. It is a volcano-tectonic depression, a tectonically controlled subsidence feature associated with volcanism and magma withdrawal.

Stratigraphy- Hydro Cone, Buldir Island, and an unnamed volcanic cone near the depression are representative of recent volcanism. Fairly continuous volcanism occurred throughout the history of the Aleutian Arc, with major pulses in the middle Eocene, middle Miocene, and Pliocene thru recent.

Prominent selanic Borisons-- Seismic horizons include basement and reflectors in the thin sedimentary section.

Gravity-- Regional gravity data has been presented by watts, 1975; and Childs, Magistrale, and Cooper, 1985a.

Maps and Other Illustrations-- see Marlow and others (1970) for a location map, line drawings of seismic profiles, and a strain-release map.

Degree of coverage-- cores and single-channel seismic profiles provide the data base for Buldir depression.

Other Information-- The depression's major axis parallels the Aleutian Ridge and its volcanic centers.

The basin flanks are steep (10 to 20 degree slopes) and straight, except in the northwest corner of the depression near Buldir Island. The depression's walls are up to $1300 \mathrm{~m} \mathrm{high}$. $\mathrm{m} / \mathrm{m} \cdot \mathrm{y} \cdot$

Subsidence rates in the depression have been estimated at 200 to 700

Southwest of Buldir depression, at lat. $50^{\circ} \mathrm{N}$. , long. $175.5^{\circ} \mathrm{E}$. , is the filled half graben (normal fault along the northeast side) of Pennant basin which has an area of about 1500 square $\mathrm{km}$ and contains about $3 \mathrm{~km}$ of upper series (Pliocene and younger) rocks (Scholl, in press). 
References-- For more detailed information see Marlow and others, 1970; Scholl and others, 1975; Watts, 1975; and Childs, Magistrale, and Cooper, 1985a.

\section{AMIA AND AMDKTA BASIMS}

General Information-- Amlia-Amukta basin is located at lat. $52^{\circ} 30^{\prime} \mathrm{N} .$, and from long. $172^{\circ} \mathrm{W}$. (Amukta) to $173^{\circ} \mathrm{W}$. (Amlia). It has an area of 5700 square $\mathrm{km}, 2700$ square $\mathrm{km}$ in Amlia and 3000 square $\mathrm{km}$ in Amukta. More than $5 \mathrm{~km}$ of upper series rocks fill Amlia basin; and about $3.5 \mathrm{~km}$ of middle(?) and upper series rocks fill Amukta basin. Water depths range from 200 to $1100 \mathrm{~m}$ in Amlia and Amukta basins (Figure 32 ).

Geologic and Gographic Boundaries-- North of the basin are Amlia, Atka, and Sequam submarine canyons. Amukta and Amlia scarps, two aligned normalfault (?) scarps as high as $650 \mathrm{~m}$, form part of the northern boundary of the basin. Southwest of the basin is Amlia Island. South of the Amukta part of the basin is Finch scarp $(400 \mathrm{~m}$ high). Amukta Island is southeast of the basin. East of the Amukta basin is Chagulak shoal, an outlying segment of the Aleutian summit platform.

Basin Shape-- The basins are rectangular. Amlia basin is $85 \mathrm{~km}$ long by $40 \mathrm{~km}$ wide and Amukta basin is $54 \mathrm{~km}$ long by $30 \mathrm{~km}$ wide. They are elongate parallel to the Aleutian Ridge and would form a single basin if they were not separated by seguam volcano (and possibly a basement ridge beneath the volcanol. Dips of flanking slopes average $2^{\circ}$ to $3^{\circ}$ except near Amlia, Amukta, and Finch scarps where they are steeper. The sea floor is deepest near scarps on the north side of the basin.

structural Cology-- Seguam Volcano, which has probably been active since the Pliocene, bisects the basin into two subbasins.

Folding increases down section; folds are commonly flanked by high-angle growth faults, suggesting deformation contemporaneous with sedimentation. "Drag" folding occurs adjacent to the basin bounding scarps and associated with intra-basin faults. A horst or fault block (possibly an intrusive body) is associated with folded and faulted beds in Amlia basin.

Basement-- Basement is the early rertiary (Cretaceous?) transitional crust of the Aleutian Ridge massif (and underlying oceanic crust?). Lower and middle series rocks (middle Eocene thru middle Miocene) form the basins' structural basement. Magnetic basement probably consists of rocks of the lower series (middle thru late Eocene). A basement high beneath sequam volcano may separate Amlia and Amukta basins. The basin seems to have formed by late Cenozoic rifting of the Aleutian arc's crestal region.

Basin Type- Amlia and Amukta basins are intra-arc summit basins associated with the axis of late Cenozoic volcanism on the Aleutian arc. The structural depressions that form the basins are grabens or half-grabens.

Stratigraphy- In Amlia basin sedimentary units are lens shaped or form northward-thickening wedges. In Amukta basin the units are more severely deformed and may be older.

Major pulses of volcanism occurred during early Tertiary arc building, in the middle Miocene, and from the late Miocene to the present. At other times, volcanism was more or less continuous but volumetrically less important. plutons intruded the ridge sequence during the middle Miocene forming contact metamorphic aureoles.

Prominent Saimic Borisons-- There is one prominent horizon separating upper series (Pliocene and younger) basin fill from middle and lower series rocks (Figure 33 ).

Cravity-- See the maps by Childs, Magistrale, and Cooper, 1985a,b; and 

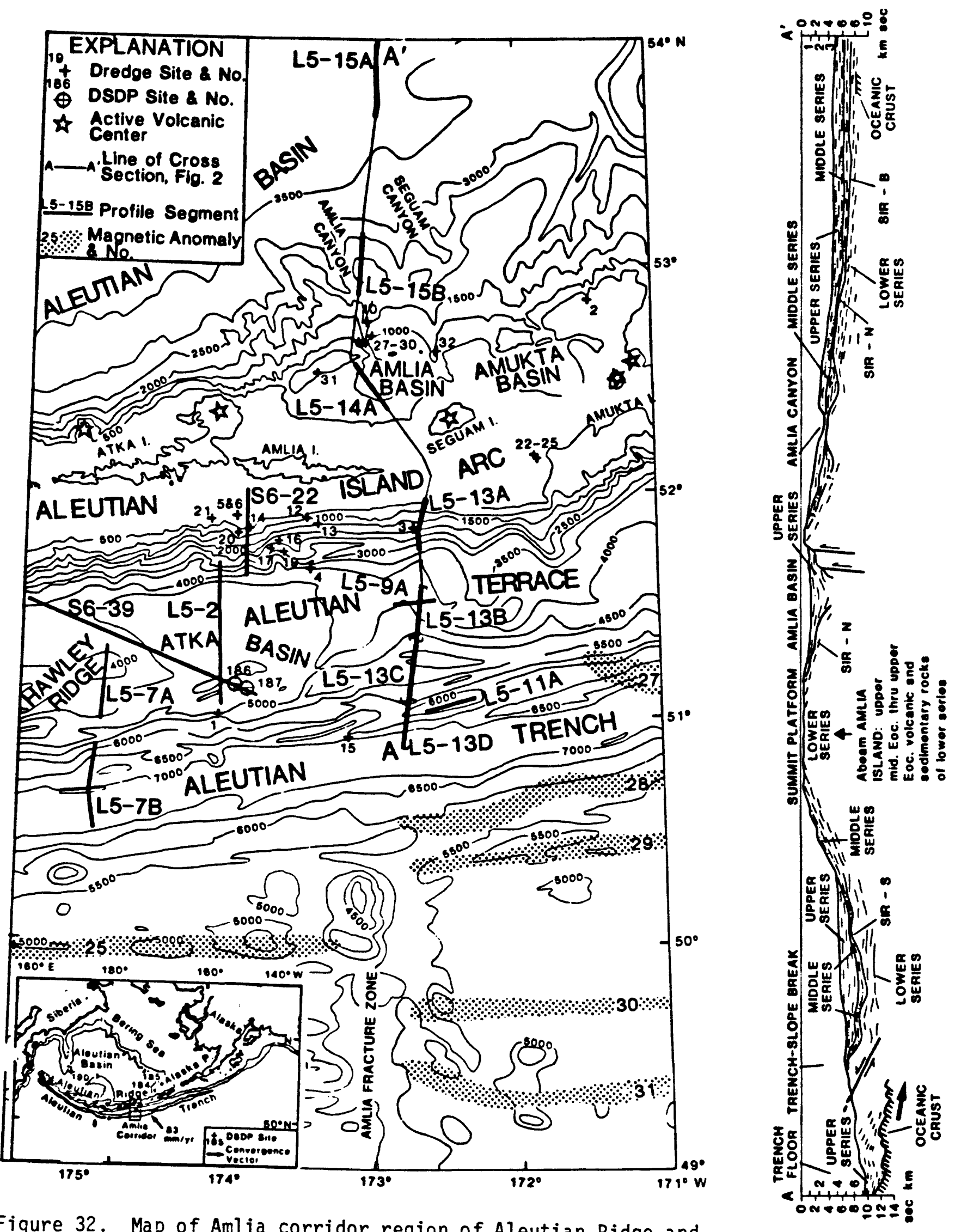

Figure 32. Map of Amlia corridor region of Aleutian Ridge and generalized cross section A-A'. From Scholl and others, 1982a. 


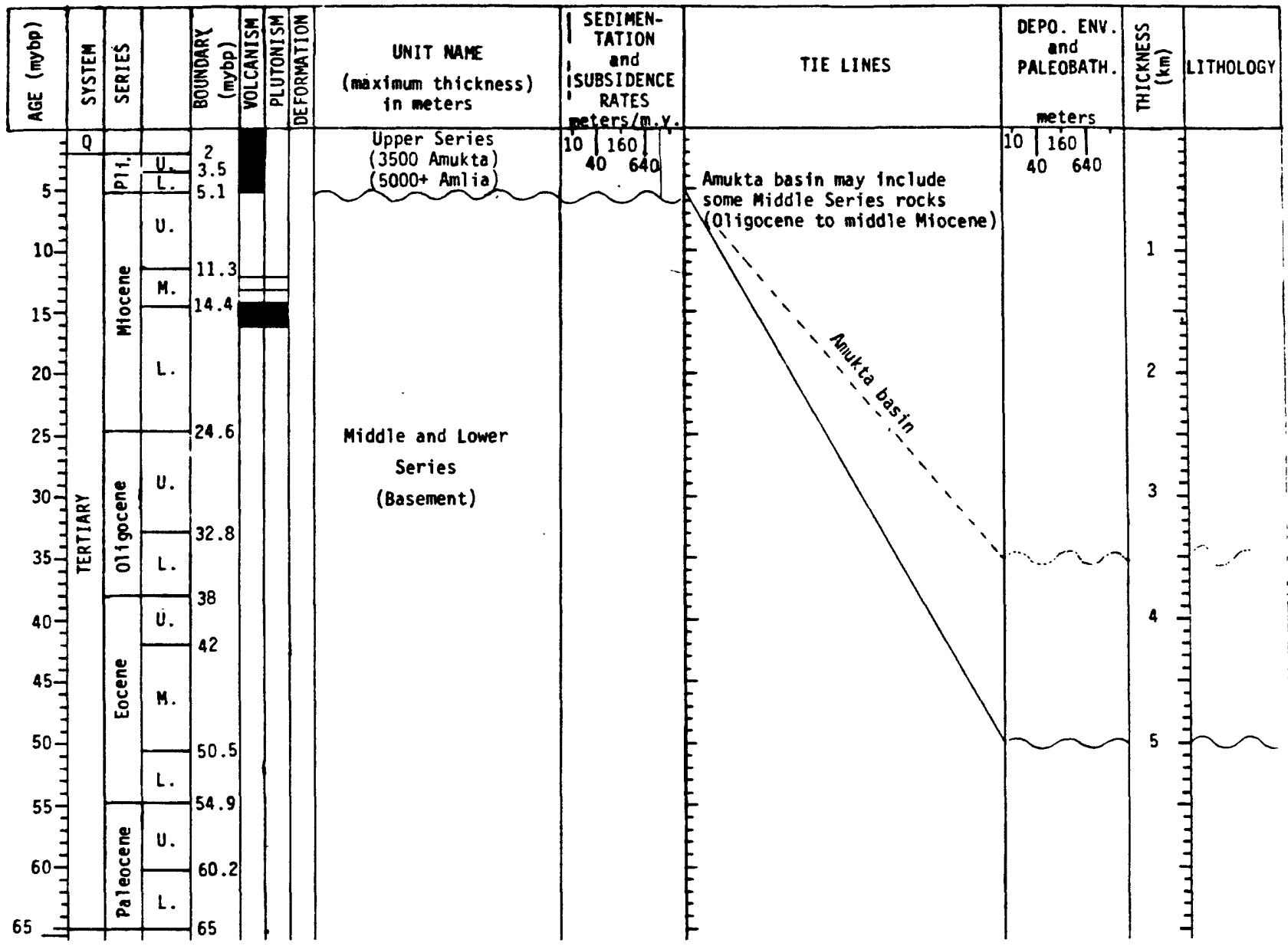

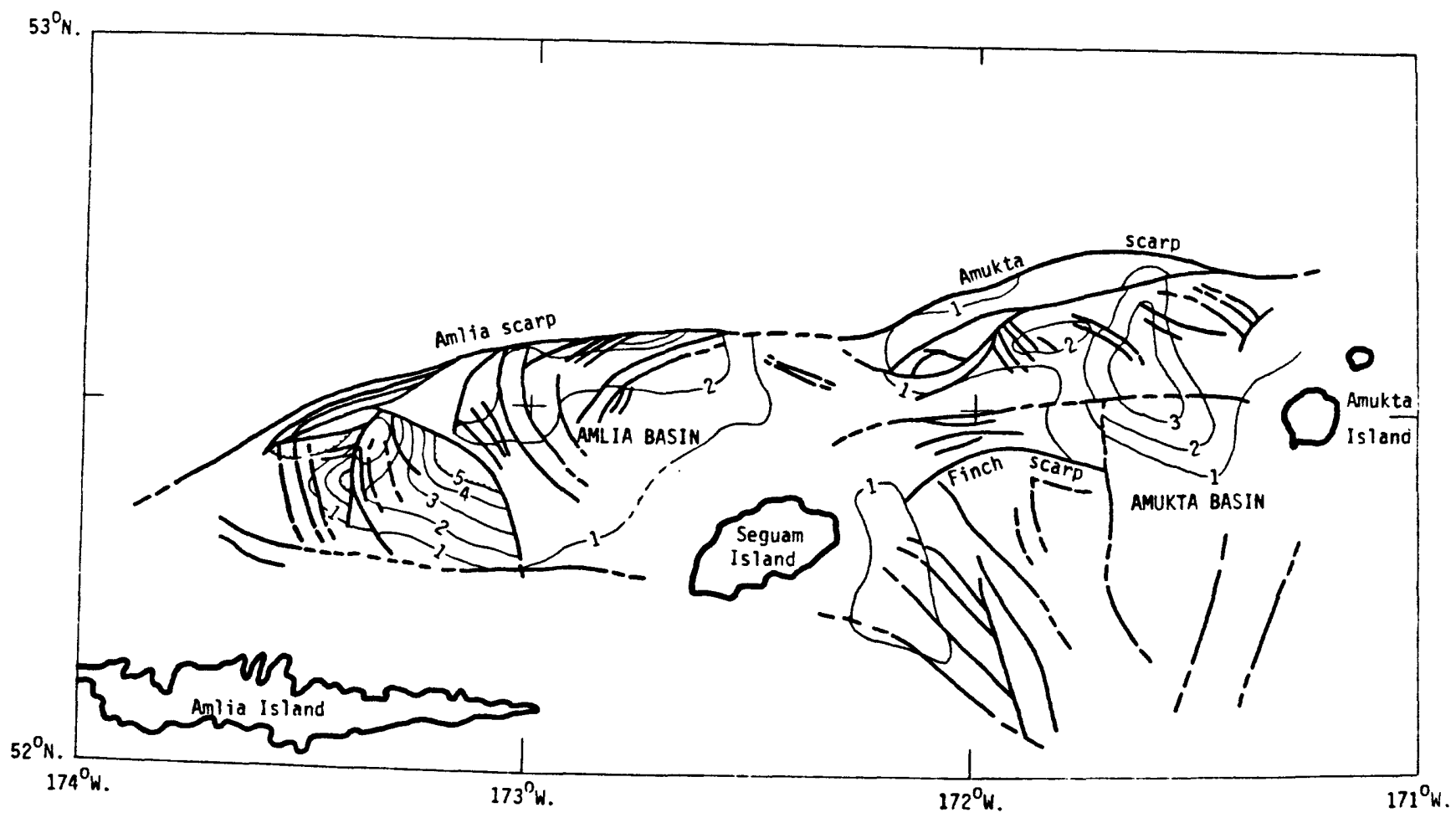

B. Isopach map of Upper Series rocks in Amlia and Amukta basins. Contour interval $1 \mathrm{~km}$. Modified from Geist, in prep. 
Watts (1975).

Magnetics-- Regional magnetic profiles appear in scholl and others, 1982; a residual magnetic map has been published by Childs, Cooper, and Wright, 1981.

Maps and Other Illustrations-- see Scholl and others (1982) for a location map, seismic profiles, and stratigraphic columns: Line drawings of seismic profiles appear in Scholl and others, 1975. See Geist, Childs, and Scholl (in press) for isopach and structure maps.

Degree of coverage-- Coverage includes two hundred kilometers of multichannel seismic reflection data in three crossing lines, 25 single channel lines, 15 dredge hauls, and 12 refraction seismic lines (sonobuoys).

other Information-- Extensional rifting of the summit platform to form Amlia-Amukta basin may be linked to initiation of late Cenozoic volcanism.

Amlia scarp is broken by passes or gaps eroded almost to the top of the basin fill. These gaps lead to submarine canyons that have apparently been eroded by clastic debris funneling through them. The position of the canyons is probably structurally controlled (Scholl and others, 1975).

Beferences-- For more detailed information see Scholl and others, 1982, 1975; Cooper and others, 1980; Watts, 1975; and Geist, Childs, and Scholl, in press.

\section{ATKA BASI,, ALEUTIAN TGRRACB PORBARC BASIN}

General Information-- Atka basin is located at lat. $50^{\circ} 30^{\prime} \mathrm{N} .$, long. $174^{\circ} \mathrm{W}$ (Figure 32). It has an area of 6000 square $\mathrm{km}$. Up to $3.3 \mathrm{~km}$ of middle Miocene and younger basin fill (upper series) are underlain by oligocene thru middle Miocene (middle series) strata that fill the Aleutian Terrace forearc basin. The combined thickness of middle and upper series strata is as much as $5 \mathrm{~km}$. The oldest known sedimentary rocks on the Aleutian Arc (lower series) are middle Eocene age. The maximum combined thickness of upper, middle, and lower series rocks is 7 to $8 \mathrm{~km}$. Water depths range from 4000 to $4700 \mathrm{~m}$.

Ceologic and Coographic Boundarles-- on the north, a $5^{\circ}$ to $6^{\circ}$ incline leads to the crest of the Aleutian ridge and the Andreanof Islands, Atka Island, and Amlia Island. In the west is Hawley Ridge, a late Cenozoic antiform. The Aleutian terrace continues further west. To the south, a steeply inclined series of west-trending, steplike linear ridges or antiformal highs of late Cenozoic age descend to the floor of the Aleutian Trench. The Aleutian Terrace forearc continues east of Atka basin.

Basin Shape-- The basin is elongate in an east-west direction. Atka basin is about $160 \mathrm{~km}$ long by $50 \mathrm{~km}$ wide, but the Aleutian Terrace forearc basin, which includes Atka basin, extends hundreds of kilometers to the east (to $164^{\circ} \mathrm{W}$. ) and to the west (to about $176^{\circ} \mathrm{E}$. ).

Landward and seaward shifts of the basin's depocenter have been caused by basement warping. The principle shift has been landward, in concert with uplift of outer terrace antiformal highs (Scholl and others, 1982). Since the pleistocene, there have been two depocenters in Atka basin, an inner depocenter in the north and east and an outer depocenter in the southwest, separated by Hawley Ridge.

structural Gology-- Late Cenozoic antiformal highs along the southern edge of the basin are associated with relative free-air gravity highs (Scholl and others, 1983), and include beds that dip as steeply as $40^{\circ}$ (Stewart, 1978).

Hawley Ridge, located on the southwestern side of the basin, is a large $(200 \mathrm{~km}$ long by $25 \mathrm{~km}$ wide by $1500 \mathrm{~m}$ high) outer terrace antiform that separates the basin into two subbasins and forms the basin's western 


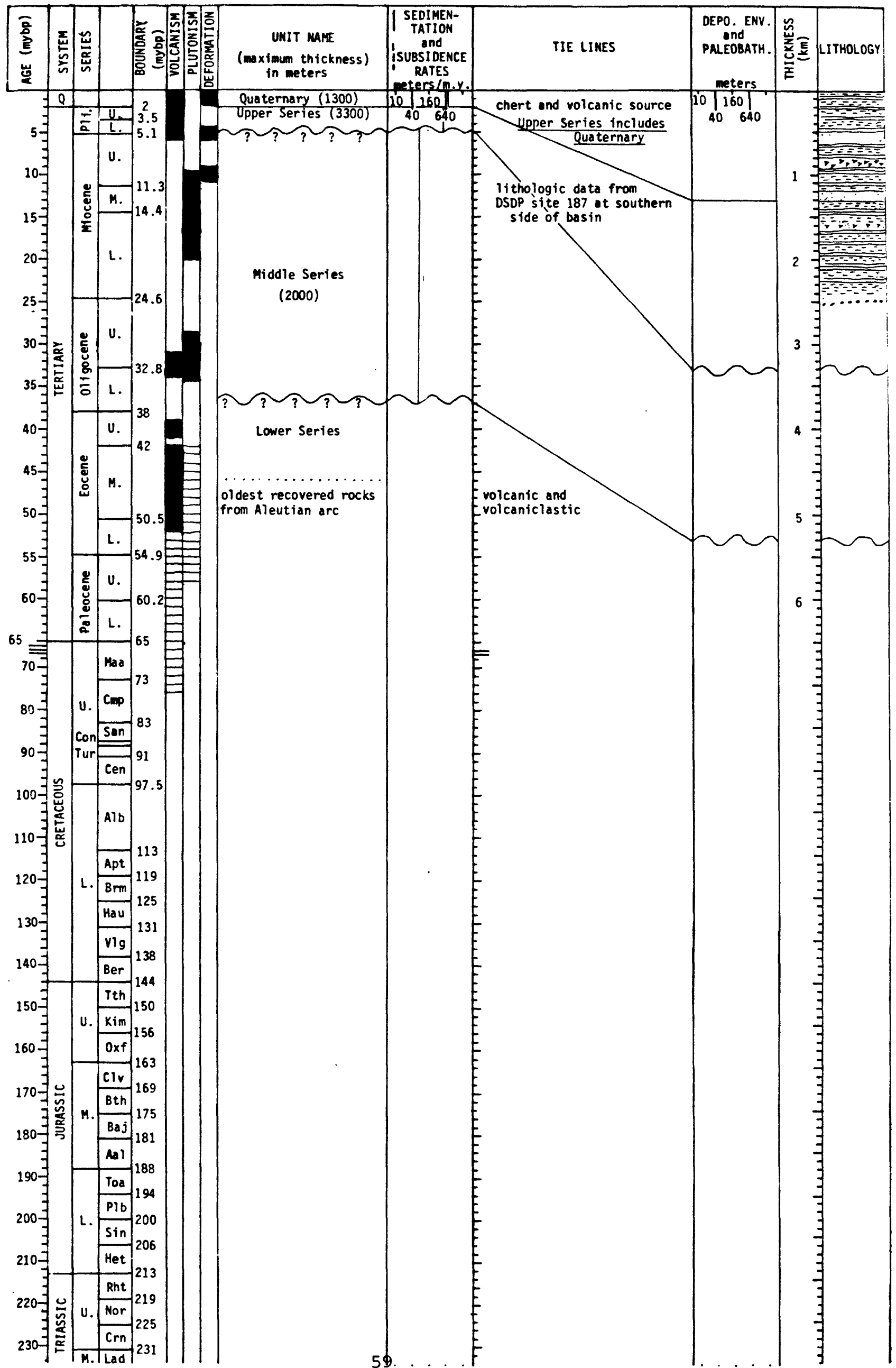


boundary. The ridge formed in the late cenozoic. Ridge.

High-angle faults are associated with antiformal highs, including Hawley

Basement-- The undulating surface at the top of the middle series forms a base on which Atka basin sediments were deposited (Figure 34). Lower series rocks with "crustal" velocities seem to be the basement rocks for the Aleutian Terrace forearc basin. Crustal basement is inferred to be Aleutian arc transitional crust.

Basin Type- Atka basin is a late Cenozoic depression in the Aleutian Terrace forearc basin.

Stratigraphy- The coarsest sediment has been deposited on the northern side of the basin, towards the arc.

Upper series sediment was deposited in lens shaped packets (scholl and others, 1982). There is a general seaward thinning of sedimentary units (Scholl and others, 1982).

Volcanism and plutonism have occurred more or less continuously since the middle Eocene and possibly earlier. Volumetrically important periods of volcanism occurred from about 52 to $39 \mathrm{Ma}, 33$ to $31 \mathrm{Ma}$, and $6 \mathrm{Ma}$ to present.

volumetrically important periods of plutonism occurred in the early (?) to middle Eocene and, north of the basin, at about $15 \mathrm{Ma}$. Contact metamorphism is associated with $15 \mathrm{Ma}$ plutonism north of the basin.

Deformation took place from about 12 to $10 \mathrm{Ma}$ and during the quaternary.

Prominent seimic Borisons- Reflections within Atka basin fill (upper series rocks) indicate large packets of lens shaped depositional units, laterally coherent, well-stratified sequences and massive sequences. Basin filling strata onlapped middle series rocks to form the terrace through continued deposition. A prominent undulatory reflection, which is at least locally an unconformity, occurs at the top of the middle series (base of Atka basin fill). Velocities in the basin fill range up to $3.2 \mathrm{~km} / \mathrm{sec}$.

Reflections within the middle series do not show thickening under Atka basin, but do show thinning southward against basement cores of seaward antiformal highs. Velocities range from 3.5 to $4.5 \mathrm{~km} / \mathrm{sec}$ in midale series rocks.

A reflector called the "Strong, Subbottom, Irregular Reflector--South" (SIR-S) is interpreted as an unconformity at the base of the middle series (top of the lower series), the surface is differentially warped with relief of 1 to $2 \mathrm{~km}$ in a distance of 5 to $10 \mathrm{~km}$ (Scholl and others, 1982).

The few coherent internal reflectors within the lower series rocks are weak and broadly undulatory. They are interpreted as primarily slope forming, not basin filling, strata. Velocities in lower series rocks range from 5.3 to $7.3 \mathrm{~km} / \mathrm{sec}$.

Gravity- A gravity model appears in Marlow and others (1973), for regional maps see Watts (1975) and Childs, Magistrale, and Cooper, 1985a.

Magnetics-- Magnetic profiles appear in Scholl and others, 1982. Paleomagnetic results indicate the arc has not undergone significant changes in latitude since its formation (Harbert, Cox, and McLean, 1984).

Petroleu Geology-- Atka basin and the Aleutian forearc have been underthrust by the Pacific plate to form the Aleutian accretionary wedge (McCarthy and others, 1984). These underplated sediments may have hydrocarbon potential and are included in this discussion.

The geothermal gradient is probably high near the arc and low near the trench. On the southern side of the basin it is estimated at 20 to $25^{\circ} \mathrm{C} / \mathrm{km}$ (Scholl and others, 1983). McCarthy and others (1984) estimate the geothermal gradient at 20.8 to $22.7^{\circ} \mathrm{C} / \mathrm{km}$ based on the depth of a reflector presumed to 
represent gas hydrate. This places the present oil generation window at depths of 3.0 to $6.5 \mathrm{~km}$.

Potential hydrocarbon-trapping structures visible on seismic profiles of the accretionary wedge include antiforms, thrust and normal faults, and stratigraphic pinchouts with up to $2 \mathrm{~km}$ of closure. Porous diatomaceous units and turbidite sands are potential reservoirs. There is no recognizable alteration of post-oligocene forearc strata outside areas of contact metamorphism.

Dewatering of subducting units could provide fluid circulation for hydrocarbon migration (Mccarthy and others, 1984). The amount of organic carbon in dredge samples ranges from 0.5 to 1.08 (Scholl and others, 1983).

Maps and Other Illustrations-- See scholl and others (1982) for a location map, structure map, and seismic profiles. Line drawings of seismic profiles appear in Marlow and others (1973).

Degree of coverage-- Six hundred $\mathrm{km}$ of multi-channel seismic lines at 50 to $75 \mathrm{~km}$ line spacing, 20 dredge hauls, 20 refraction seismic lines, and DSDP sites 186 and 187 cover the basin.

Other Informtion-- At DSDP site 187 the sediment provenance is QFL = $5,30,75 . \mathrm{C} / Q=0.68$. $\mathrm{Lv} / \mathrm{Lt}=0.96$. Fp/Ft $=0.97$. Where $Q$ is quartz, $F$ is feldspar, $L$ is lithic fragments, $C$ is chert, $v$ is volcanic, $p$ is plagioclase, and $t$ is total (Stewart, 1978).

A displaced block of middle Miocene terrace sediments in the upper Pliocene section was drilled at DSDP site 186 (Stewart, 1978; Scholl and others, 1982).

In the late cenozoic there were intense episodes of canyon cutting (Scholl and others, 1982).

Onshore exposures of middle series sedimentary rocks are rare in the Amlia Corridor.

References-- For more detailed information see McCarthy and others, 1984: Stewart, 1978; Scholl and others, 1975, 1982, 1983; Marlow and others, 1973; and Watts, 1975.

\section{ALEOTIAN TRENCH}

General Information-- The Aleutian trench lies along a curve from lat. $56^{\circ} \mathrm{N}$., long. $150^{\circ} \mathrm{W}$. to lat. $50^{\circ} \mathrm{N}$., long. $180^{\circ}$ to lat. $53^{\circ} \mathrm{N} .$, long. $169^{\circ} \mathrm{E}$. The maximum measured thickness of the trench fill is $4 \mathrm{~km}$ in the Amlia corridor (Figure 35). The trench fill probably includes Late cretaceous (?) and Tertiary oceanic sediments (of unknown thickness) overlain by Quaternary sediments (Figure 36). Water depths are near $7300 \mathrm{~m}$.

Geologic and Ceographic Boundaries-- The Aleutian Ridge lies north of the trench. To the west the trench continues to the Kamchatka Peninsula. South of the Aleutian trench lies the northern Pacific Ocean basin and Zodiac fan. To the east the trench continues to the Middleton segment of the Gulf of Alaska.

Quein shape- The Aleutian Trench is elongate parallel to the Aleutian arc. The thickest part of the sedimentary section filling the trench is in the north, towards the arc. Trench fill is probably thicker near sediment sources at the trench ends--Alaska and Kamchatka source areas.

structural ceology-- The inner trench slope overlies a thrust thickened sequence of trench-floor deposits that thin towards the trench. Gently deformed, rotated masses or blocks within this sequence are probably no older than late Cenozoic.

Within the trench, Quaternary sediments up to 0.5 million years old show northward dips which increase from 0.2 degrees at the seafloor to 5 to 6 


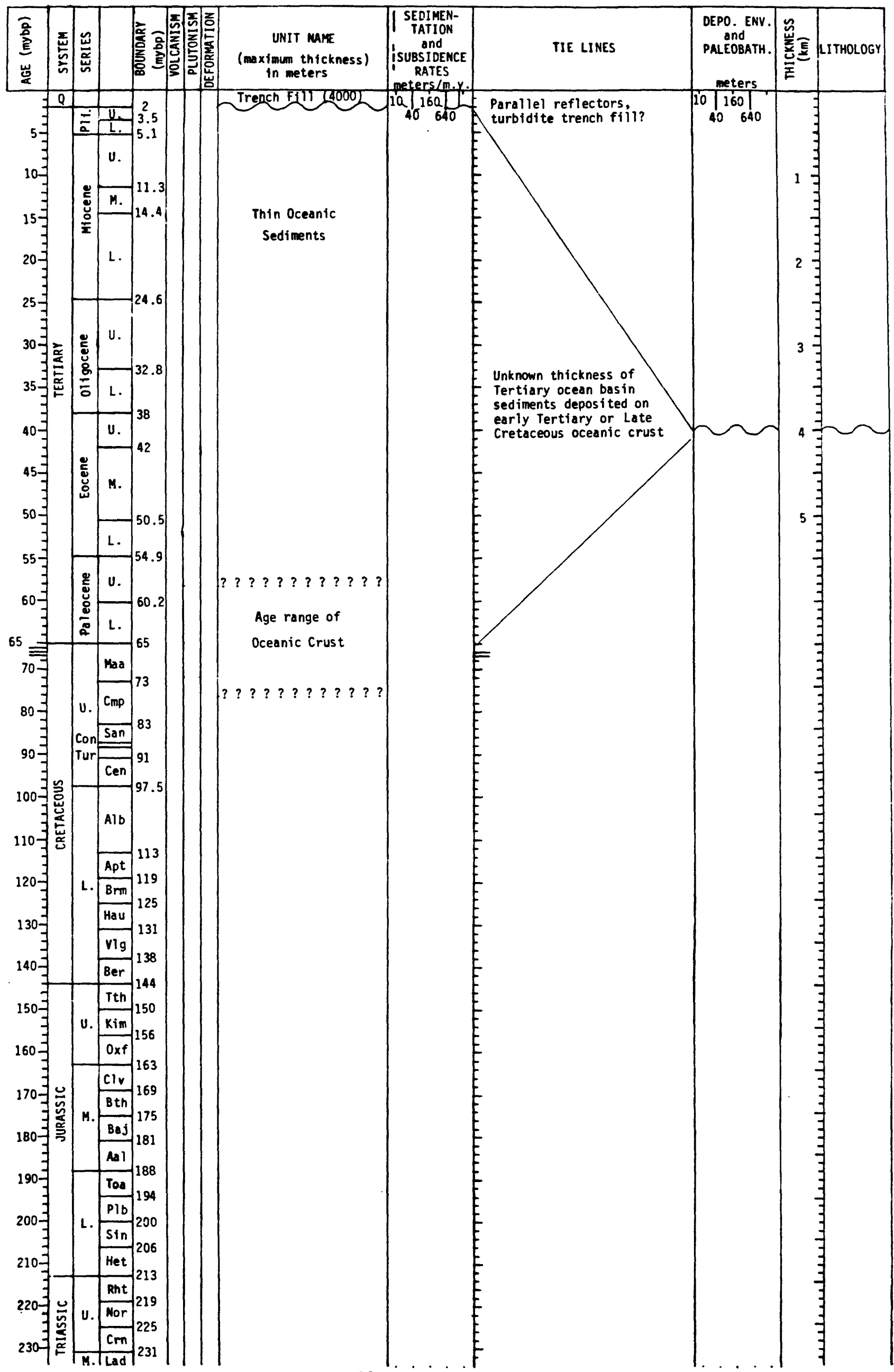




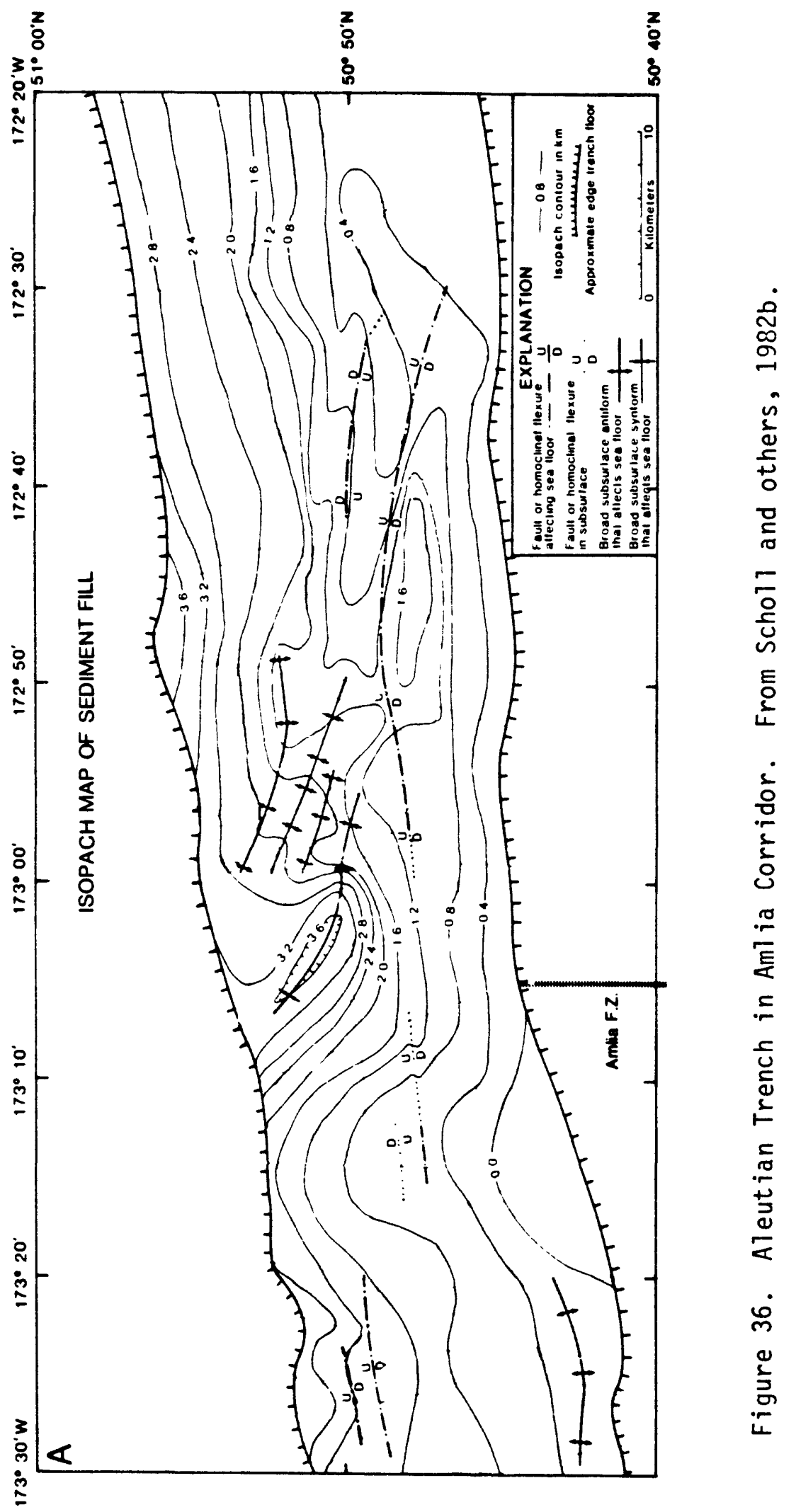


degrees adjacent to the oceanic basement.

Subsurface antiforms and synforms trend parallel or slightly oblique to the axis of the trench. The folds are superimposed above ridges and swales in oceanic basement and their amplitudes increase with depth, suggesting the structures result from bending of the Pacific plate into the Aleutian subduction zone.

Near long. $173^{\circ} \mathrm{W}$. , west-trending ridges and troughs are present on the seaward (southern) slope of the trench.

Basement-- Crustal and acoustic basement is Late Cretaceous to early Tertiary oceanic crust. Basement is offset by a right-lateral fracture zone in the Amlia corridor and is probably similarly offset in other areas. Beneath trench filling sediment, the basement surface dips 4 to 10 degrees to the north. It lies 8 to $10 \mathrm{~km}$ subsurface beneath the trench-slope break.

Basin Type-- The basin is a trench; however, the western parts of the trench are presently in oblique or strike-slip regimes.

Stratigraphy-- Quaternary turbidites that fill the trench have a source at the eastern end of the trench suggesting an overall coarsening and thickening of the basin fill towards the east. A similar situation exists in the west where the Meiji sediment tongue (Siberian source) fills and oversteps the trench.

Sedimentary units on the pacific side of the trench are wedge-shaped and thicken toward the trench axis. On the landward slope, tectonically-thickened wedges thin toward the trench floor.

Prominent Seismic Borizons-- Parallel reflectors below the trench floor are interpreted as a wedge of Quaternary turbidites. Landward of this turbidite wedge is a wedge of uplifted trench deposits of post middle Miocene age. Younger units onlap oceanic crust and the overlying ocean basin sediments (Figure 35 ).

Gravity-- Gravity modeling based on seven gravity profiles across the trench is presented in Marlow and others (1973). Free-air gravity profiles are published in Scholl and others (1982a). Free-air gravity mapping is published by Childs, Magistrale, and Cooper, 1985a.

Magnetics-- Total field residual magnetic profiles appear in Scholl and others (1982a). West-trending magnetic anomalies are present in the oceanic basement (Scholl and others, 1982b).

Maps and Other Illustrations-- Location, isopach, and structure-contour maps, along with seismic profiles and cross sections, appear in Scholl and others (1982b) for the Amlia fracture zone sector of the Aleutian trench.

Degree of coverage-- Three DSDP core holes near the trench (sites 183, 186, 187), dredge hauls, multichannel seismic reflection data.

References-- For more detailed information see Scholl and others, 1982a, b; Marlow and others, 1973; and McCarthy and others, 1984.

\section{SANAK BASIN}

General Information-- Sanak basin is located south of the Alaska peninsula at lat. $54^{\circ} \mathrm{N}$. , long. $171^{\circ} \mathrm{W}$. It has an area of about 7000 square $\mathrm{km}$ and lies in water depths of up to $1200 \mathrm{~m}$ (less than $200 \mathrm{~m}$ in central Sanak subbasin, 200 to $1200 \mathrm{~m}$ in east Sanak subbasin). Sanak basin contains more than $8 \mathrm{~km}$ of Miocene and younger sedimentary fill (Figures 37 and 38 ). It is part of the Shumagin planning area.

Geologic and Ceographic Boundaries-- North of Sanak basin is the Alaska Peninsula and its Jurassic thru Quaternary sedimentary section. Deer Island and Sandman reefs are northwest of the basin. Sanak Is land, composed of isoclinally folded Cretaceous turbidites with minor chert and rare pillow 


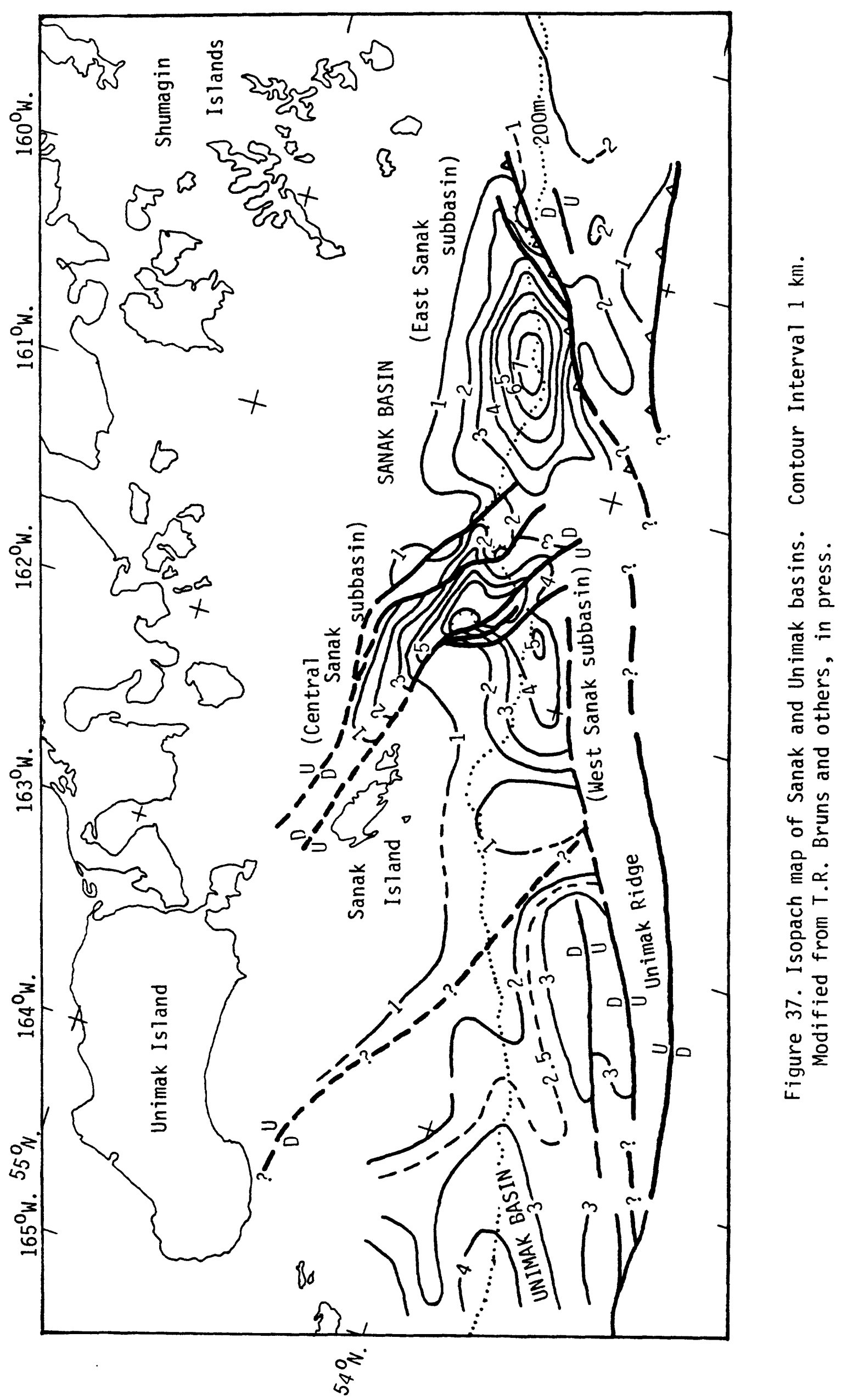


Bruns and others, in press.

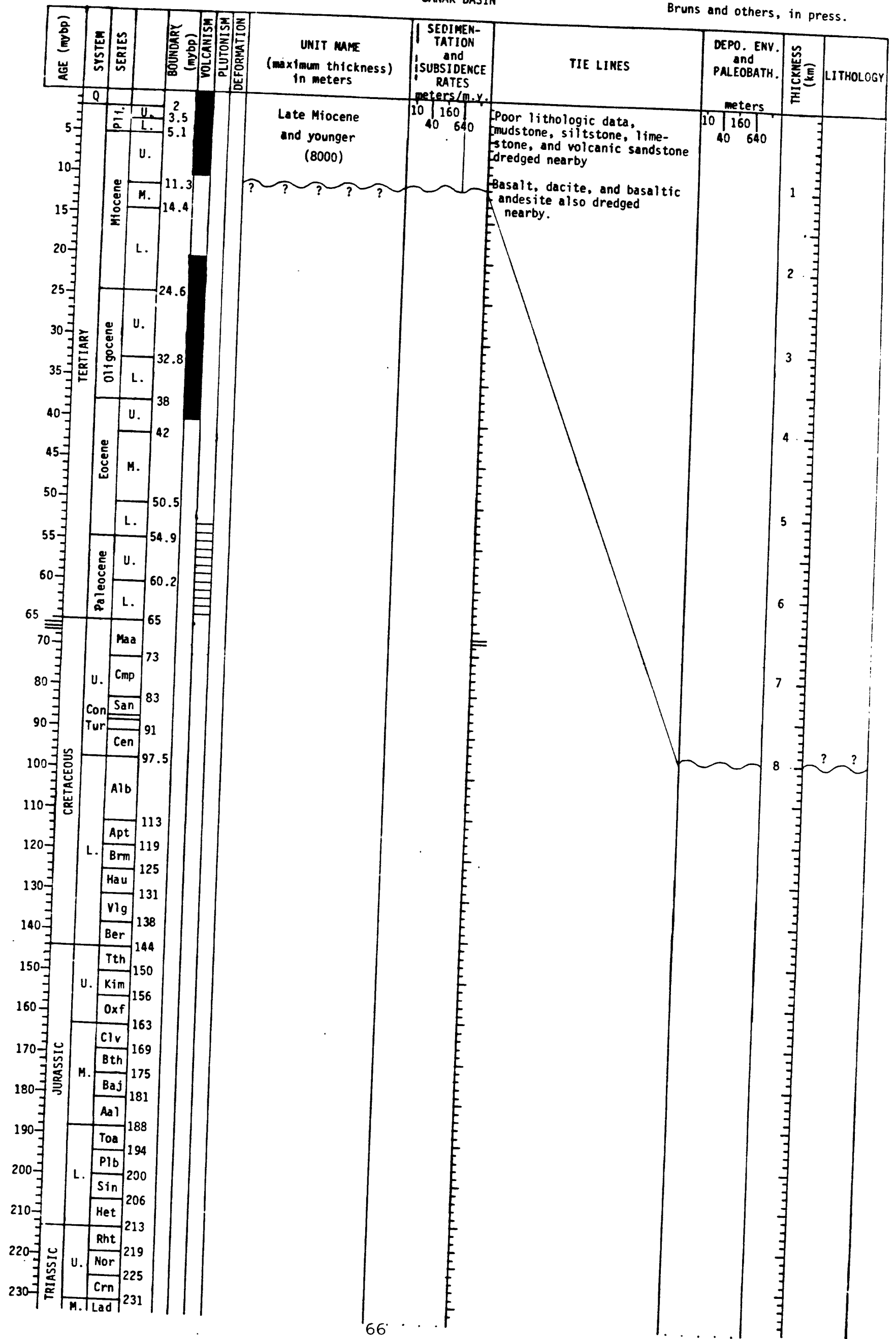




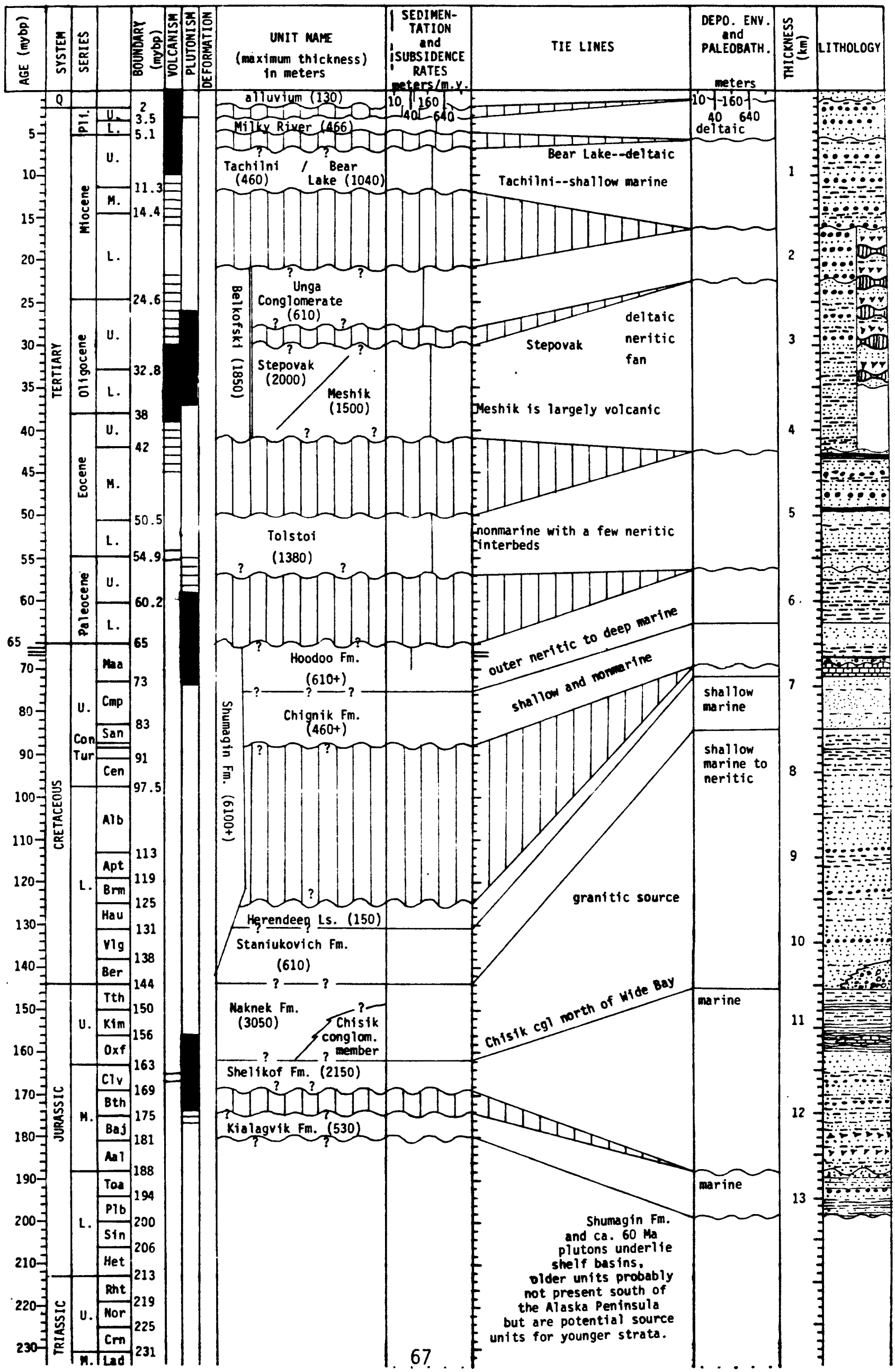


basalt (Moore, 1974) lies west of the basin. On the southwest, the basin boundary may be a fault. Down-to-basin normal faults form the southeastern and eastern boundaries of the basin. Shumagin Islands lie northwest of a fault that defines the northeastern edge of the basin.

Basin Shape-- The basin is divided into three subbasins, east, central, and west. East and central sanak subbasins are more than $7 \mathrm{~km}$ deep, west Sanak is $5 \mathrm{~km}$ deep. The major depocenters of the eastern and western subbasins lie north of a faulted basement high. East and west Sanak subbasins are elongate along an east-northeast trend. East Sanak subbasin is $100 \mathrm{~km}$ long by $40 \mathrm{~km}$ wide and west Sanak is $40 \mathrm{~km}$ long by $25 \mathrm{~km}$ wide. Central Sanak subbasin is elongate along a northwest trend, $80 \mathrm{~km}$ long by $25 \mathrm{~km}$ wide.

structural Gology-- Normal faults bound the central subbasin; there is evidence for up to $5 \mathrm{~km}$ of vertical displacement on these faults. Deformation increases with depth. There are broad anticlinal folds in the basin.

Basement-- Acoustic basement is probably made up of deformed Mesozoic sedimentary rocks (Cretaceous Shumagin Formation) and early Tertiary granitic plutons (inferred from magnetic anomalies and nearby outcrops). Crustal basement is probably transitional crust of the Chugach, Prince william, and Peninsular terranes underlain by subducted oceanic crust of early Tertiary age.

Basin Jype-- Sanak basin is a fault-bound, graben-like basin, a forearc (intra-arc?) basin.

Stratigraphy- Arc volcanism occurred nearby on the Alaska Peninsula. Paleocene (ca. 60 Ma) granitic plutons crop out on Sanak Island (Figure 39).

Rocks of the Shumagin Formation (acoustic basement) are metamorphosed to zeolite facies. There is probably contact metamorphism associated with the early Tertiary plutons.

Prominent Seimic Borizons- The top of the acoustic basement is a major unconformity.

Gravity-- Free-air gravity is discussed in Bruns and von Huene, 1977.

Magnetics-- See Bruns and von Huene (1977) for a discussion of magnetics.

Petroleum Geology-- Organic carbon values from the Shumagin shelf area average 0.2 to 0.38 , maximum 0.78 . The geothermal gradient is probably 25$30^{\circ} \mathrm{C} / \mathrm{km}$ (Bruns and others, in press).

Maps and Other Illustrations-- See Bruns and von Huene (1977) for location maps, seismic profiles, and cross sections. An isopach map is shown in Figure 37.

Degree of coverage- 780 kilometers of geophysical data were collected in 1975 and 1981. 4000 kilometers of multichannel seismic reflection profiles and 49 seismic refraction profiles are available for the entire Shumagin shelf.

Other Information-- West of west Sanak subbasin, south of Unimak Island, and west of a margin oblique down-to-the-west fault (fault zone?) is Unimak basin (Figure 37; Bruns and others, in press). The basin fill $(4.5 \mathrm{~km})$ is ponded behind Unimak ridge in the east, but forms a seaward prograding wedge to the west; the nature of the western boundary of the basin is unknown.

Beferences-- For more detailed information see Bruns and von Huene, 1977; Burk, 1965; Moore, 1974; Moore and others, 1983; Moore, 1974; Bruns and others, in press; and Plumley and others, 1983.

SHOAGIA BASIM

Ceneral mformation-- Shumagin basin is located at lat. $55^{\circ} 30^{\prime} \mathrm{N} .$, long. $158^{\circ} 30^{\prime} \mathrm{W}$. It has an area of 3800 square $\mathrm{km}$ in water depths less than $200 \mathrm{~m}$. Shumagin basin contains up to $2.5 \mathrm{~km}$ of late Miocene and younger fill. The 


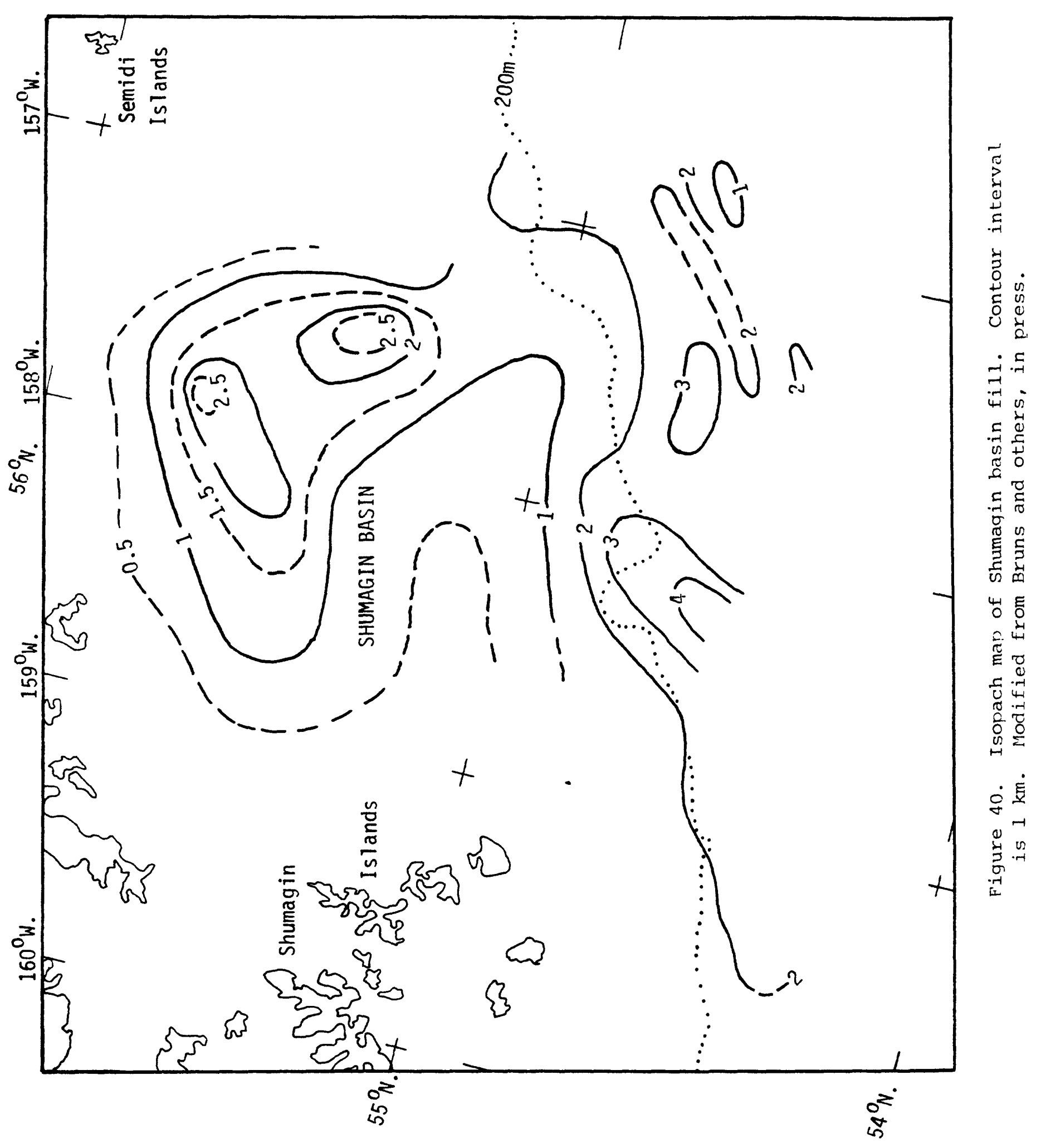


Figure 41

Data from Bruns and von Huene, 1977

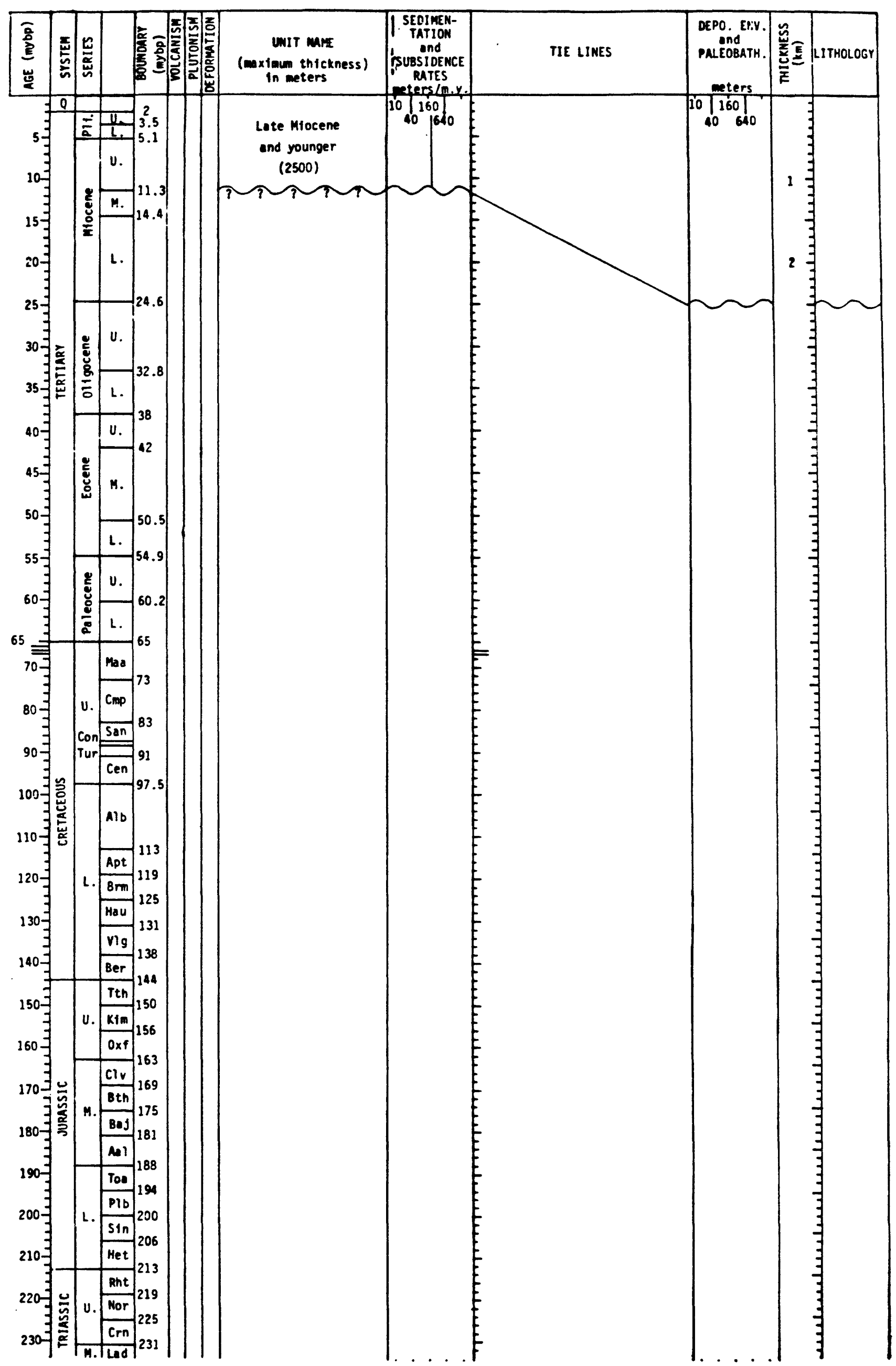


basin is in the Shumagin planning area.

Ceologic and Ceographic Boundaries-- North and northwest of Shumagin basin is the Alaska Peninsula and its exposures of Mesozoic and Tertiary sedimentary rocks. On the Shumagin Islands, west of the basin, Tertiary intrusive rocks and deformed cretaceous turbidites crop out. South of the basin are the shelf edge and the Aleutian Trench. To the east is the Kodiak shelf. Northeast of the basin are the Semidi Islands, where Tertiary intrusive rocks are exposed.

Basin Shape-- Shumagin basin is " $v$ " shaped in plan view. It has a steeper basement slope and thicker stratigraphic sequences in the north, east, and southeast (Figure 40 ).

Structural Golog:- Within Shumagin basin, small near vertical faults cut all but the youngest stratigraphic units. Uplift has occurred in the southeastern part of the basin.

Basement-- Acoustic basement consists of deformed Mesozoic sediments, probably the cretaceous Shumagin Formation, and early Tertiary intrusive rocks inferred from magnetic anomalies and observed in nearby outcrops.

Crustal basement is inferred to include early Tertiary granitic plutons, transitional (?) crust of the Prince william, Chugach, and Peninsular terranes, and early Tertiary $(53$ to $60 \mathrm{Ma})$ oceanic crust subducting beneath the continental margin.

Basin mype-- Shumagin basin is a sag or depression in acoustic basement, a forearc basin.

Prominent Seignic Borisons-- Acoustic basement lies beneath a major unconformity (Figure 41).

Gravity-- Free-air gravity is discussed in Bruns and von Huene, 1977.

ragnetics-- See Bruns and von Huene (1977) and Plumley and others (1983) for a discussion of magnetism.

Petroleum Geology-- Organic carbon values as high as 0.78 have been recorded. Average organic carbon is 0.2 to 0.38 . Geothermal gradients were probably $25-30^{\circ} \mathrm{C} / \mathrm{km}$ (Bruns and others, in press)

Zeolite facies metamorphism has occurred in some parts of the Upper Cretaceous Shumagin Formation.

Naps and Other Illuatrations-- See Bruns and von Huene (1977) and Bruns and others (in press) for location and structure-contour maps and seismic profiles.

Degree of coverage-- There is dredge data from Unimak seamount and from off the Shumagin Islands. 817 kilometers of geophysical data was collected over the basin in 1975 and 1981.

References-- For more detailed information see Bruns and von Huene, 1977; Burk, 1965; Moore and others, 1983; Bruns and others, in press; and Plumley and others, 1983.

\section{TUGIDAK BASIN}

Coneral Information-- Tugidak basin is located at lat. $56^{\circ} 15^{\prime} \mathrm{N}$. , long. $155^{\circ} 30^{\prime}$. It has an area of 3000 square $\mathrm{km}$ in water depths of less than 300 m. The basin is filled with up to $5 \mathrm{~km}$ of upper Miocene and younger sediment (Figures 42 and 43). Tugidak basin is part of the Kodiak planning area.

Geologic and Geographic Boundaries-- Shelikof Strait, Rodiak Island, and the Alaska Peninsula lie north of the basin. On the northwest a magnetic anomaly has been correlated with the Border Ranges fault. Semidi Islands (Tertiary intrusive rocks) lie west of Tugidak basin. The Shumagin shelf and Shumagin basin lie southwest of Tugidak basin. Basin filling strata, along with oligocene sedimentary rocks, crop out on Chirikof Island south of the 


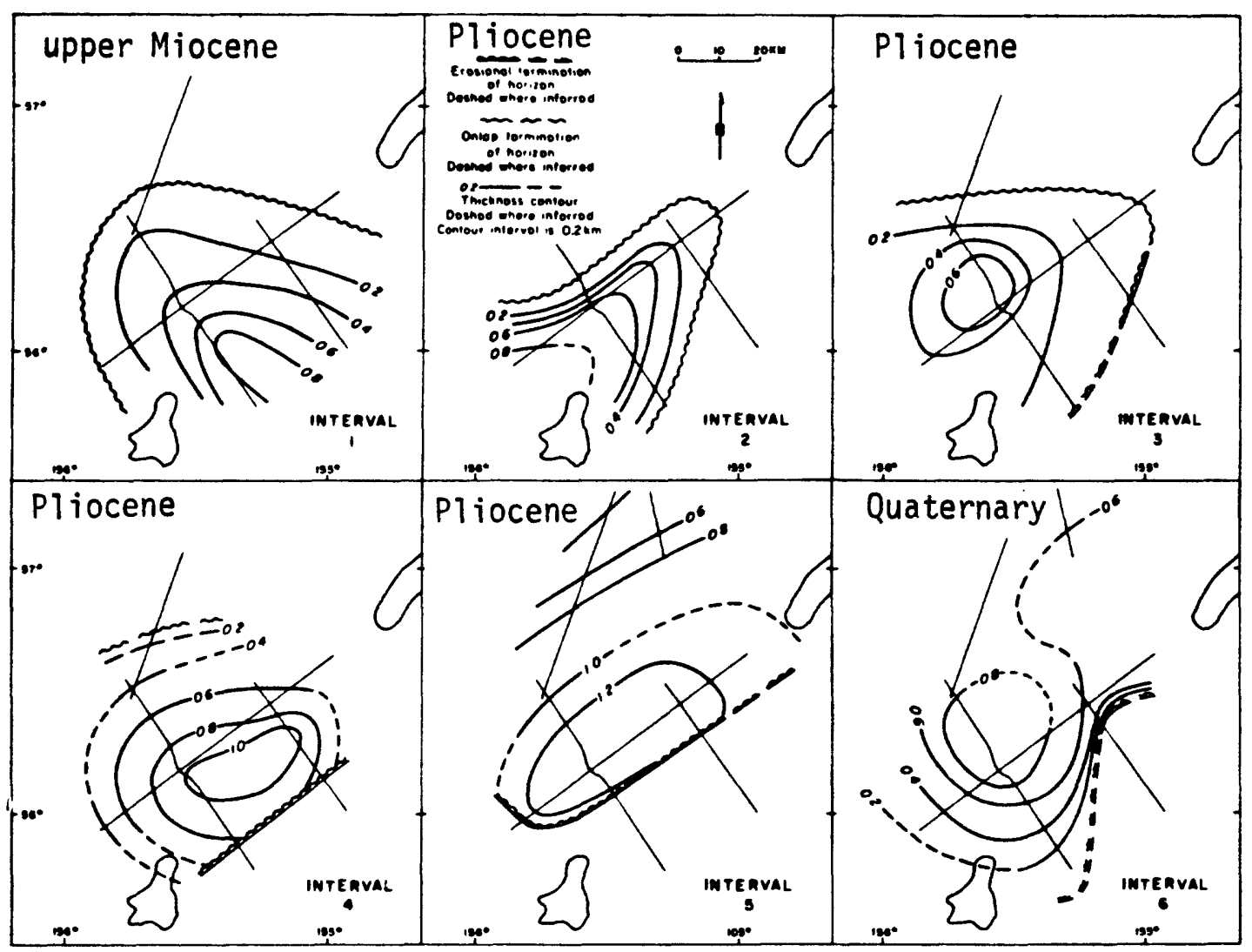

Figure 42. Isopach maps of strata intervals in Tugidak basin. Intervals shown on Figure 43. From Fisher, 1979. 


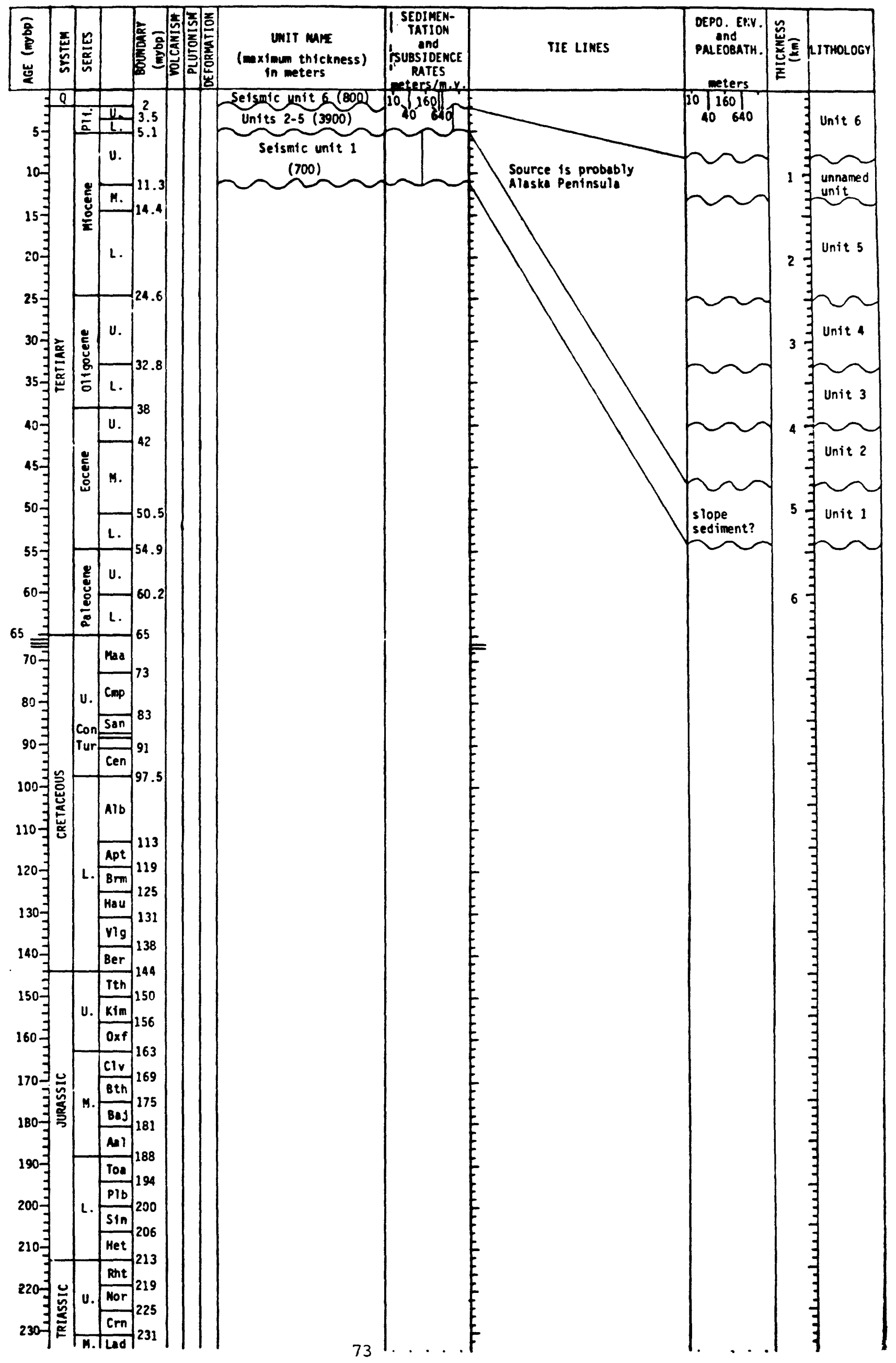


basin. Trinity basin and Tugidak uplift--an anticline that began to form in the early Pliocene--are located southeast of Tugidak basin. The northeast end of Tugidak uplift and a northwest-trending down-to-the-southeast fault form the eastern boundary of the basin. A basement high, possibly an extension of Kenai-Kodiak ridge, is onlapped by Tugidak basin fill to the northeast; it is breached in places by channels and may have been subaerially exposed. Tugidak Island, with its exposures of $\mathrm{Pliocene}$ and younger sedimentary rocks, lies northeast of the basin.

Basin Shape- Tugidak basin is circular in plan view The sedimentary section is thicker in the southeast. During seismic intervals 2 thru 5 (Pliocene) the basin was elongate along a southwest-northeast trend. During seismic interval 1 (late Miocene) the basin was elongate northwestsoutheast. The main depocenter has shifted landward with time (Figure 42 ).

Structural Geology-- Tugidak basin is broadly synclinal. Folds, including many that parallel the Tugidak uplift southeast of the basin, show increasing deformation with depth and are at least partly contemporaneous with basin filling. There are small normal faults in the northwestern parts of the basin and small reverse faults in the southeastern parts of the basin. These faults show increasing throw with depth, and are at least partly contemporaneous with basin filling. Deformation of the basin-filling strata seems to be of $\mathrm{Pliocene}$ age.

Basement-- Acoustic basement of deformed Tertiary and Cretaceous flysh is inferred from onshore outcrops, seismic reflection and refraction data, and magnetic data (Figure 44). Crustal basement is probably transitional or oceanic crust. Locally, intrusive rocks of Paleocene age are exposed.

Basin Type-- Tugidak basin is a forearc basin. Formed on a convergent margin, it is a slope basin that was later silled on its seaward side by the Tugidak uplift.

Stratigraphy-- Volcanism occurred nearby froil 65 to $46 \mathrm{Ma}$ (mafic), 44 to $20 \mathrm{Ma}$, and $10 \mathrm{Ma}$ to present. Quartz-diorite plutons exposed on Rodiak and Semidi Islands range in age from 65 to $55 \mathrm{Ma}$ and granodiorite plutons on the Alaska Peninsula range in age from 40 to $27 \mathrm{Ma}$.

Prominent seivalc Borizons-- There are six prominent seismic horizons defining six seismic intervals (Figure 43). Interval 1 is interpreted as late Miocene. Intervals 2 thru 5 are interpreted as pliocene. Interval 6 is interpreted as Pleistocene.

Gravity-- See Fisher, von Huene, and Steele, 1983.

ragnetics- Paleomagnetics puts the Chugach terrane at lat. $29^{\circ}$ to $38^{\circ} \mathrm{N} .(3)$ at 37 to $43 \mathrm{Ma}$ and the Prince william terrane at lat. $16^{\circ}$ to $34^{\circ} \mathrm{N} .(?)$ at 60 to $65 \mathrm{Ma}$ (Moore and others, 1983; Gromme and Hillhouse, 1981). See Fisher (1979) for magnetic profiles.

Petroleu Ceology-- The geothermal gradient for the Kodiak Shelf is estimated at $20^{\circ}$ to $30^{\circ} \mathrm{C} / \mathrm{km}$.

Maps and other Illustrations-- see Fisher (1979) for location, isopach, and structure maps and also for seismic profiles, and cross sections. A structure map and stratigraphic columns appear in Fisher and von Huene, 1982.

Degree of coverage- The basin is covered by a multichannel seismic grid with $60 \mathrm{~km}$ spacing.

References-- For more detailed information see Fisher, 1979, 1980; Moore, 1969 ;ilson and Moore, 1979; Fisher and von Huene, 1980, 1982; Moore and others, 1983; and Plumley and others, 1983. 
Data from Fisher, 1979; Moore, 1969 ;

(Southern and eastern sides)

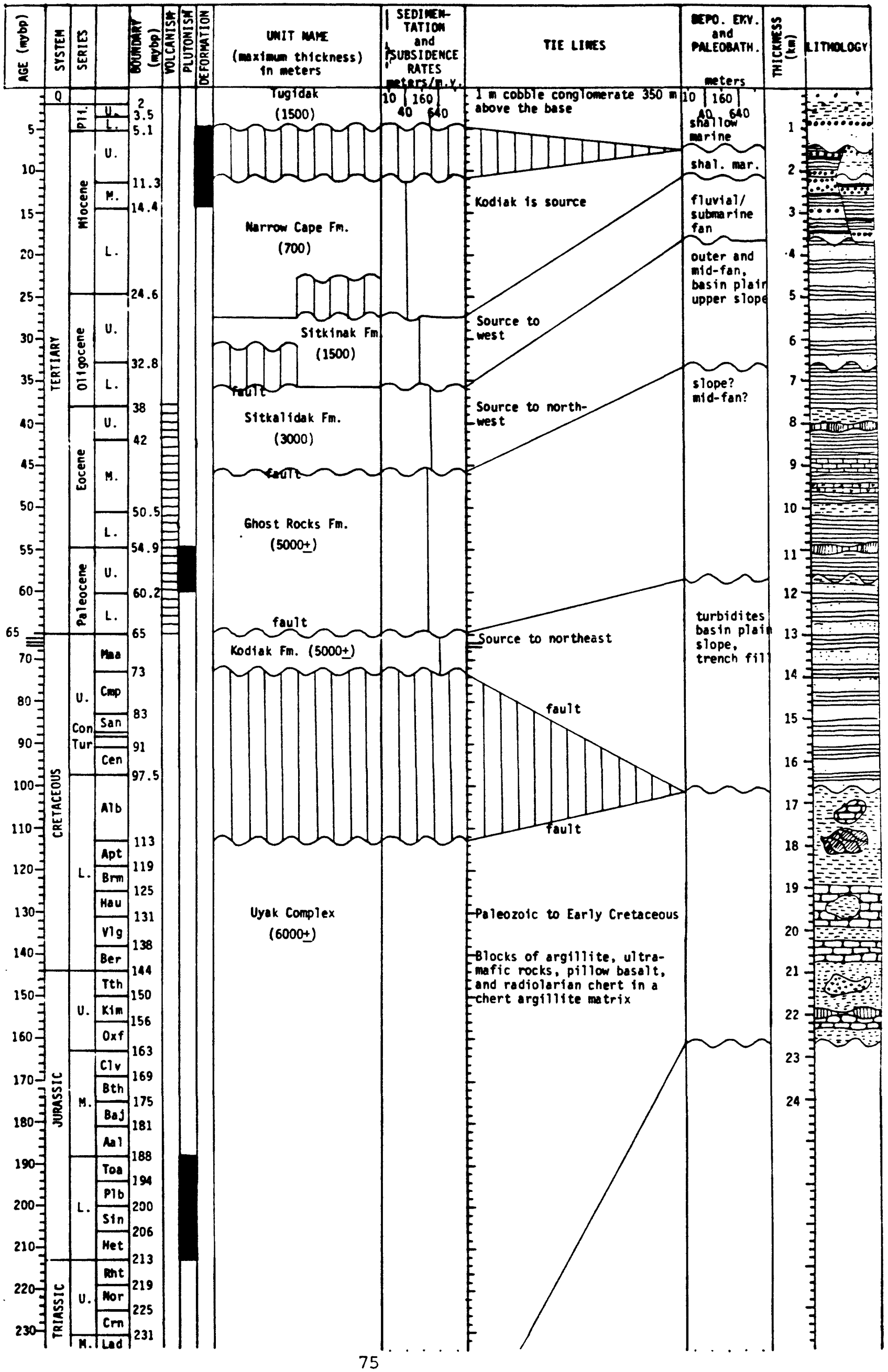




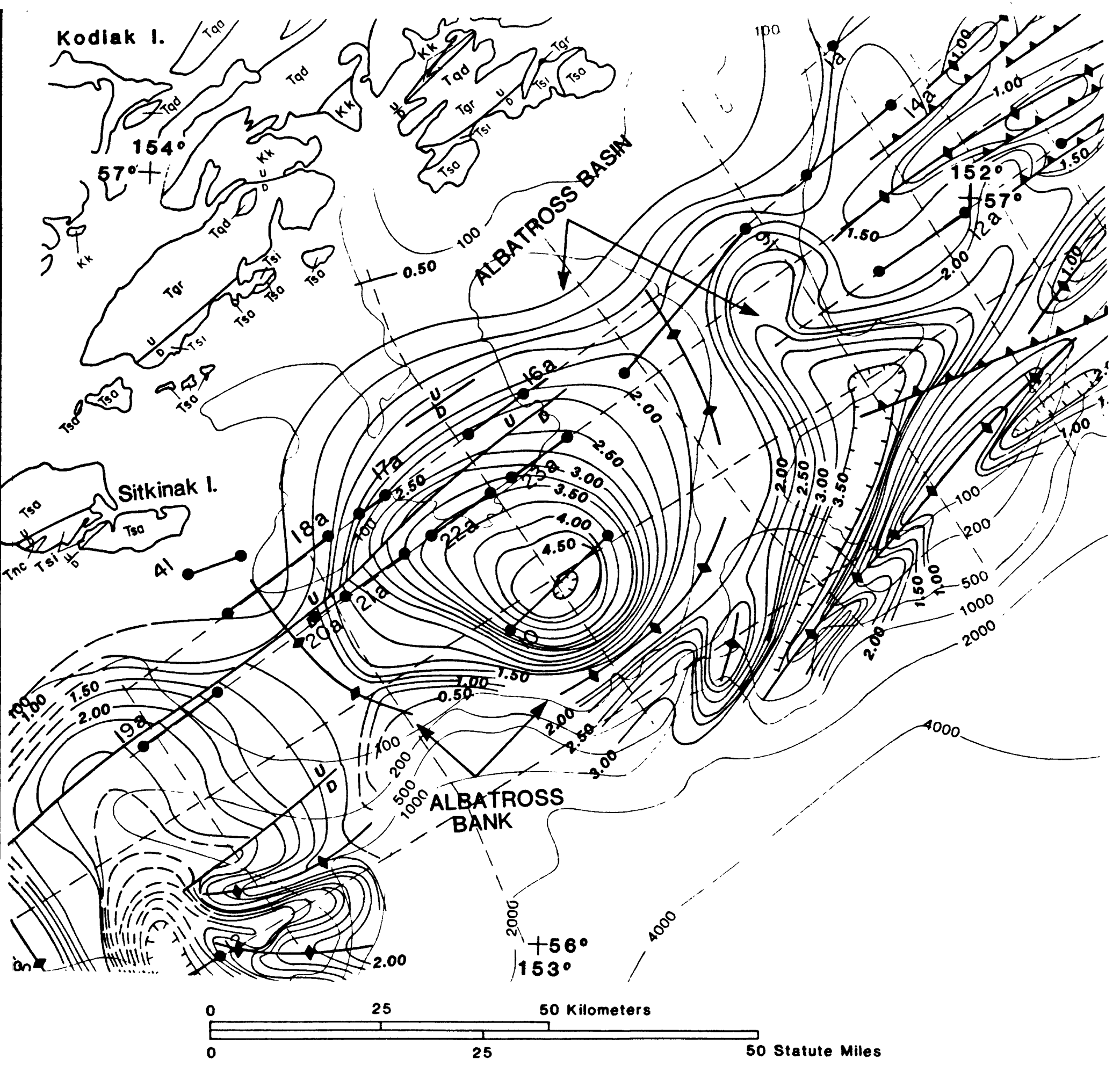

Figure 45. Structure map of Albatross basin. Contours on pre-middle (?) Miocene unconformity. Contour interval $0.25 \mathrm{~km}$. Dashed lines are seismic reflection profiles. Solid lines with filled circles are seismic refraction lines. Tnc--middle Miocene to upper 01 igocene (?) Narrow Cape Fm., Tsi--01igocene Sitkinak Fm., Tsa--0ligocene and Eocene Sitkalidak Fm., Tgr--Eocene and Paleocene Ghosts Rocks Fm., Tqd--Paleocene quartz-diorite, Kk--upper Cretaceous Kodiak Fm. From Fisher and von Huene, 1982. 
Data from Fisher and von huene, 1980;

Fisher, pers. comen, 1983

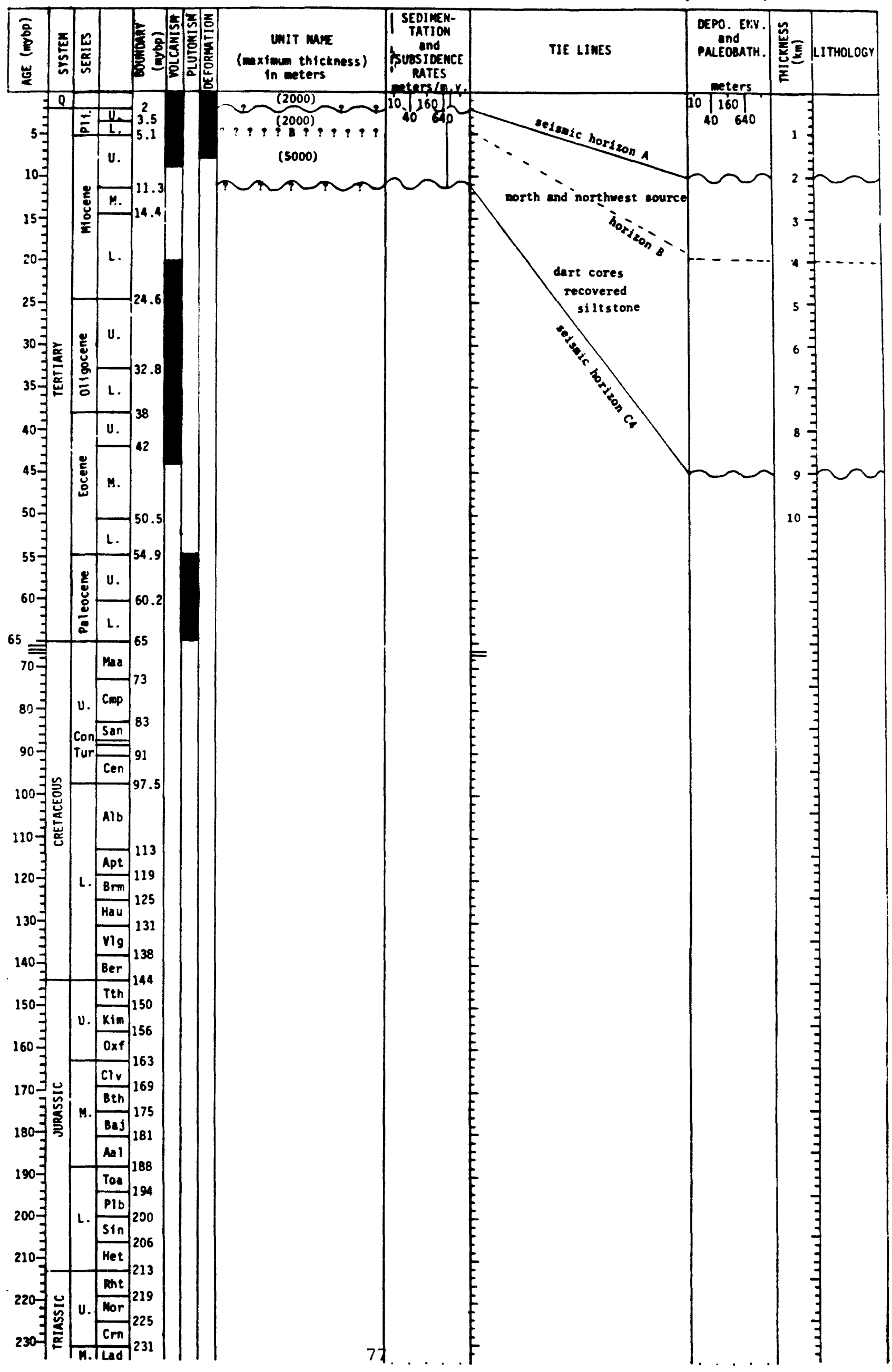


and long. $152^{\circ}$ to $154^{\circ} \mathrm{W}$. It has an area of 6000 square $\mathrm{km}$, with most of the area in water depths less than $200 \mathrm{~m}$ (some parts are as deep as $1500 \mathrm{~m}$ ). Albatross basin contains up to $5 \mathrm{~km}$ of late Miocene and younger fill. The basin is divided into two subbasins, eastern and western. The eastern subbasin contains $3 \mathrm{~km}$ of basin filling sediment and the western $5 \mathrm{~km}$ of fill. Albatross basin is in the Kodiak planning area.

Geologic and Ceographic Boundaries-- Kodiak Island, with its Paleocene intrusive rocks and Mesozoic and Tertiary sedimentary rocks (Figure 44), lies north and northwest of the basin. On the northwest side of the basin are upto-the-northwest faults. The Tertiary sedimentary section of Sitkinak Island is exposed west of Albatross basin. Albatross bank forms the southern and southwestern boundary of the basin. In the southeast there is an erosional truncation of the basin fill. The eastern edge of the basin rests along a northeast-trending anticline. Dangerous Cape High forms the northeastern boundary of the basin.

Basin shape- The eastern and western subbasins are separated by Albatross Bank (Figure 45). The western subbasin is circular in map view $(60$ $\mathrm{km}$ in diameter), but in cross section the basement surface is steeper beneath the basin's southern side. Originally the western subbasin's floor dipped to the southeast, but the depocenter migrated landward as Albatross Bank grew. The eastern subbasin is " $Y$ " shaped with the bottom of the " $Y$ " to the southwest. The eastern subbasin is about $70 \mathrm{~km}$ long and $40 \mathrm{~km}$ wide; in cross section it is symmetrical.

Structural Cology-- Deformation has been fairly continuous since the late Miocene. Albatross Bank is a broad arch composed of four anticlines that have been uplifted more than three kilometers since Miocene or Pliocene time. The bank has been breached in several places by erosion. The easttrending part of Albatross Bank is older than the northeast-trending part. A complicated intersection of anticlinal structures, Albatross Bank curves around the southwestern, southern, and southeastern sides of the western subbasin. This is the most tectonically active area on the Kodiak Shelf (Fisher and von Huene, 1980).

Within the basin is a system of open folds and faults, most of which strike northeast. Prominent among these is a set of high-angle reverse faults.

The sea floor shows relect topography, including glacial features.

Basement-- Acoustic basement is formed by pre-Miocene deformed sedimentary rocks. The presence of melange is inferred from high seismic velocities, lack of good reflectors, weak magnetic signatures, and lack of gravity anomalies. Basement is probably composed of rocks like those exposed on Kodiak Island. A difference in velocity between rocks near the shelf break and those near shore suggests two basement blocks may be present.

crustal basement includes the Prince william Terrane (underthrust by subducting oceanic crust and intruded by Paleocene plutons?).

Basin Type-- Albatross basin is a shelf forearc basin with strata ponded behind a seaward high.

Stratigraphy- quartz-diorite plutons were intruded from 65 to $55 \mathrm{Ma}$. Volcanism occurred from 45 to $20 \mathrm{Ma}$ and from $10 \mathrm{Ma}$ to present.

Prominent Seiemic Borizons-- Horizon " $A$ " is interpreted as an erosional unconformity at the base of the Pleistocene (Figure 46). Horizon " $B$ " is a horizon of unknown nature that is probably Pliocene in age and related to the uplift of Albatross Bank. Horizon " $C$ " has been interpreted as an unconfomity at the base of the Pliocene or possibly upper Miocene. This smooth horizon may be a subaerial or shallow-marine erosional surface. 
Cravity-- See Fisher, von Huene, and Steele, 1983.

Petroleum Geology-- The geothermal gradient for the Kodiak shelf has been estimated at between 20 and $30^{\circ} \mathrm{C} / \mathrm{km}$ (Fisher, 1980).

ups and Other Illustrations-- For location and structure-contour maps, as well as seismic profiles and stratigraphic columns, see Fisher and von Huene, 1980, 1982.

Degree of coverage-- Data include a seismic refraction study and a multichannel seismic reflection grid with $30 \mathrm{~km}$ spacing. Data has not yet been released from 6 cosT wells on the Kodiak shelf.

References-- For more detailed information see Fisher, 1979, 1980; Fisher and von Huene, 1980, 1982; Holmes and others, 1978; Moore and others, 1983; Hudson, 1979; and Plumley and others, 1983.

\section{SHEVBNSON BASIN}

General mformation-- Stevenson basin is located from lat. $57^{\circ} 30^{\prime}$ to $59^{\circ} \mathrm{N}$., long. $148^{\circ} 30^{\prime}$ to $150^{\circ} 30^{\prime} \mathrm{W}$. It has an area of 7500 square $\mathrm{km}$, all of which is in water less than $400 \mathrm{~m}$ deep. Stevenson basin is filled with more than $7 \mathrm{~km}$ of Pliocene (late Miocene?) and younger sediment. There are two subbasins in Stevenson basin, the southwestern subbasin has a $7 \mathrm{~km}$ thick section and the northeastern subbasin has a $3.5 \mathrm{~km}$ thick section. Stevenson basin is in the Kodiak planning area.

Geologic and Ceographic Boundaries-- The Kenai Peninsula and Afognak Island lie north of Stevenson basin. Cook Inlet, the Barren Islands, and Shuyak Island are west of the basin. Dangerous Cape High forms the basin's southern and southwestern boundaries. A broad anticline forms a shelf-edge uplift that lies along the eastern and southeastern margins of the basin. There is no data for the area northeast of Stevenson basin.

Basin Shape-- The two subbasins are separated by Portlock anticline. The southwestern subbasin is elongate along an east-west trend with a steeper basement surface beneath its southern side (Figure 47). The northeastern subbasin is symmetrical along a southwest-northeast line and is slightly deeper in the east. Northeastern closure of the basin has not yet been defined.

structural Ceology-- Portlock anticline trends east-northeast and separates the two subbasins. A system of down-to-the-southeast normal faults has a northeasterly trend.

Basement-- Acoustic basement probably comprises pre-Miocene deformed sedimentary rocks and melange (inferred from seismic, gravity, and magnetic data). Crustal basement is the Prince william terrane, underthrust Cretaceous or early Tertiary oceanic crust, and Paleocene intrusives.

Basin Type- Stevenson basin is a forearc basin with a seaward high.

Stratigraphy-- Paleocene quartz-diorite intrusives are exposed on nearby Kodiak Island.

Prominent seimic Borisons-- Borizon " $A$ " is interpreted as representing the base of the Pleistocene (Figure 48). Horizon " $\mathrm{C}$ " is interpreted as the base of the Pliocene, but could be late Miocene.

Petroleun Geology-- The geothermal gradient for the Kodiak shelf has been estimated at 20 to $30^{\circ} \mathrm{C} / \mathrm{km}$.

Mape and other Illustrations-- See Fisher and von Huene $(1980,1982)$ for location and structure-contour maps and for seismic profiles and stratigraphic columns.

Degree of coverage-- Most of the basin is covered by a multichannel seismic grid with $30 \mathrm{~km}$ line spacing.

References-- See Fisher, 1980; Fisher and von Huene, 1980, 1982; Plumley 


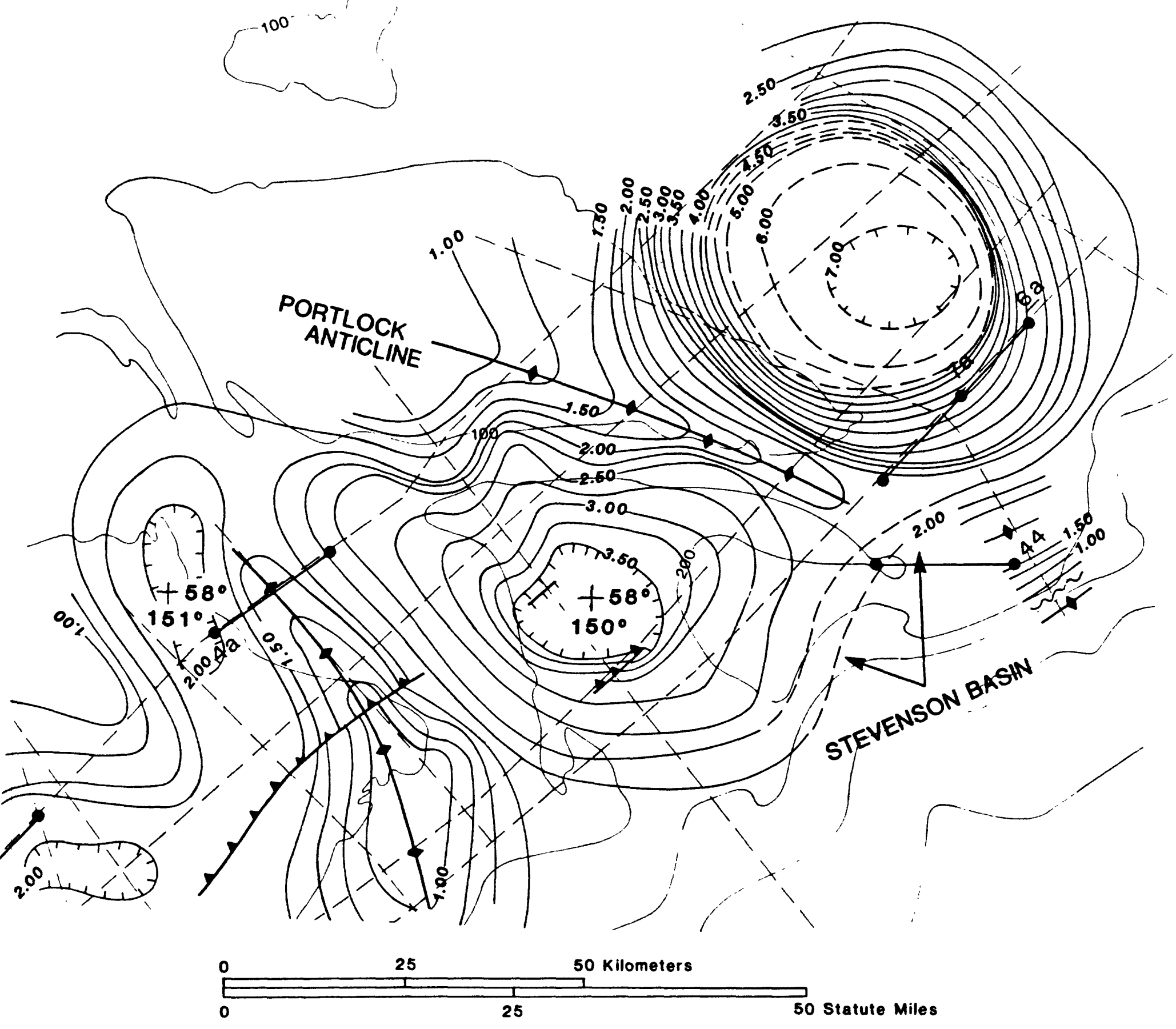

Figure 47. Structure map of Stevenson basin. Contours on a pre-middie (?) Miocene unconformity. Contour interval $0.25 \mathrm{~km}$. Dashed lines are seismic reflection profiles. Solid lines with filled circles are seismic refraction lines. From Fisher and von Huene, 1982. 
Data from Fisher and von Huene, 1980; 1982

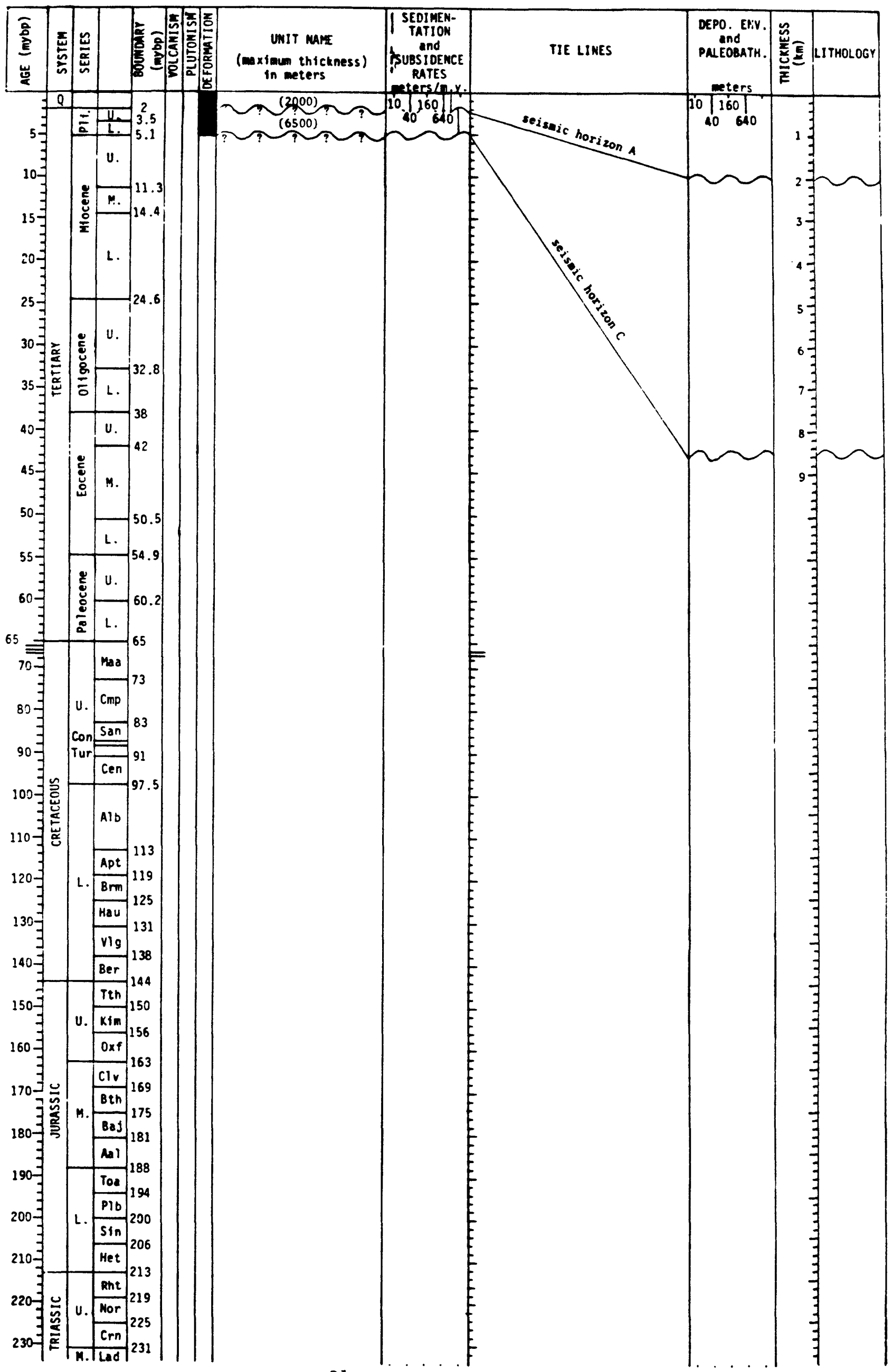


and others, 1983; and Moore and others (1983) for more information.

\section{COOR-SHELIKOF BASIN}

General Information-- Cook-Shelikof basin is located at lat. $57^{\circ}$ to $61^{\circ} \mathrm{N}$., long. $149^{\circ}$ to $156^{\circ} \mathrm{W}$. It has an area of 40,000 square $\mathrm{km}$; water depths are less than $300 \mathrm{~m}$. Up to $7 \mathrm{~km}$ of Tertiary and $12 \mathrm{~km}$ of Mesozoic sedimentary strata fill (or underlie) the basin. Cook-Shelikof basin is in the cook Inlet planning area.

Ceologic and Cographic Boundaries-- The castle Mountain right-lateral fault and Susitna basin lie north of cook-Shelikof basin. The Bruin Bay fault (a high-angle reverse fault with more than $3 \mathrm{~km}$ throw) and, beyond that, Alaska and Aleutian Ranges batholiths form the northwestern margin of the basin. Southwest and south of the basin are the Semidi Islands, Kodiak shelf, Kodiak Island, and Tugidak basin. The Border Ranges fault--a suture zone-bounds the Mesozoic basin fill on the southeastern side of cook-Shelikof basin, but is overstepped by Tertiary strata that onlap the Chugach Mountain front. Deformed cretaceous sedimentary rocks of the Chugach terrane crop out east of Cook-Shelikof basin in the Kenai-Chugach Mountains. To the northeast, a thin corridor of sedimentary rocks extends inland to the copper River basin.

Basin Shape- In the late Mesozoic the basin was elongate along a northeast-southwest trend and was open to the southeast. Near the end of the Mesozoic the depocenter shifted along the basin axis, from southwest to northeast. The Tertiary basin remained elongate along a northeast-southwest trend and symmetrical in cross section, but was closed to the southeast.

structural cology-- The main part of the basin is formed by two large, northeast-trending synclines that lie north and south of the AugustineSeldovia arch (Figure 49). These may have originally formed a single structure that was later interrupted by formation of the arch. The synclines are Late Cretaceous structures.

Augustine-Seldovia arch is a Late cretaceous to Tertiary structure that trends normal to the basin axis ( $80^{\circ} \mathrm{W}$ at lat. $59^{\circ} 20^{\prime} \mathrm{N}$., long. $153^{\circ} \mathrm{W}$ ).

Small folds, trending $4^{\circ} \mathrm{E}$., parallel the basin bounding faults. In the extreme northern part of the basin the folds have a more northerly trend. Where the folds are asymmetrical, they have steeper western flanks. These folds are mainly of Pliocene age.

Two periods of faulting and folding (Maastrichtian-Paleocene and Eoceneoligocene) disrupted the cook-Shelikof basin fill.

Basement-- Acoustic basement beneath the southeastern side of cook Inlet is probably composed of upper Triassic pillow basalt, volcaniclastic rocks, and limestone. Beneath the northwestern and central parts of the basin, acoustic basement is thought to represent (1) Permian limestone or (2) intrusive rocks with enclosed remnants of Devonian and Silurian sediments (exposed as roof pendants in the Alaska-Aleutian range batholith).

Crustal basement consists of continental crust northwest of the Border Ranges fault (Peninsular Terrane) and transitional or oceanic crust southeast of the Border Ranges fault (Chugach Terrane).

Basin Type-- Cook-Shelikof basin has been a forearc basin throughout the Cenozoic. However, potassium oxide trends in the Alaska Range batholith suggest it may have been a backarc basin at some time during the Mesozoic.

stratigraphy-- coarse-grained units in Cook-Shelikof basin (Figure 50) include: (1) Sterling Formation conglomerates of Pliocene-Pleistocene age, (2) Beluga Formation conglomerates of late Miocene age, (3) Hemlock conglomerate of late oligocene age, (4) West Foreland Formation conglomerates of early Eocene age, and (5) the Chisik Conglomerate of Late Jurassic age. 